
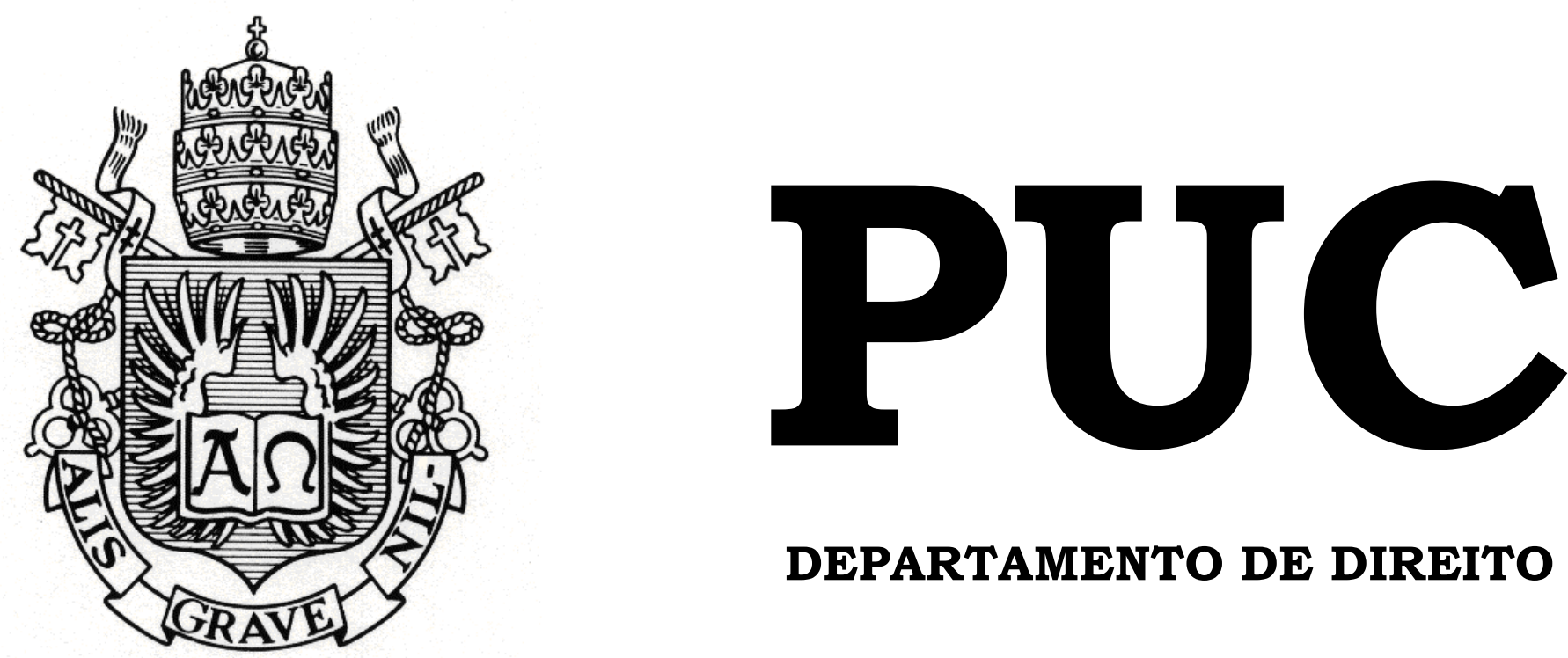

DEPARTAMENTO DE DIREITO

\title{
O DEVER DE PREVENÇÃO ESTABELECIDO PELA CORTE INTERAMERICANA DE DIREITOS HUMANOS
}

por

\section{PAULO HENRIQUE DA SILVA TAVARES}

ORIENTADORA: Márcia Nina Bernardes

2015.2

PONTIFÍCIA UNIVERSIDADE CATÓLICA DO RIO DE JANEIRO

RUA MARQUÊS DE SÃO VICENTE, 225 - CEP 22453-900

$$
\text { RIO DE JANEIRO - BRASIL }
$$




\title{
O DEVER DE PREVENÇÃO ESTABELECIDO PELA CORTE INTERAMERICANA DE DIREITOS HUMANOS
}

\author{
por \\ PAULO HENRIQUE DA SILVA TAVARES
}

Monografia

apresentada

ao

Departamento de Direito da Pontifícia Universidade Católica do Rio de Janeiro (PUC-Rio) para a obtenção do Título de Bacharel em Direito.

Orientadora: Márcia Nina Bernardes 
Dedico este trabalho ao meu querido irmão, João Pedro Fragoso da Silva Tavares $(J P)$.

A certeza de que um dia estaremos todos juntos novamente. 


\section{AGRADECIMENTOS}

Ao longo dos cinco anos deste curso de Direito, eu tenho muito o que agradecer a todos que estiveram ao meu lado. Agradeço a Deus, pela minha saúde e pela família que tenho. Agradeço a Puc-Rio, na pessoa do professor Augusto Sampaio, pela concessão integral da bolsa-Puc por todo o curso. Estudar na melhor instituição de ensino superior privada do Brasil, é um verdadeiro privilégio.

Agradeço a minha querida e amada mãe, por tudo o que fez e faz por mim, por dedicar a sua vida em função dos filhos, por todos os dias, sem exceção, sempre acordando cedo para preparar o meu café da manhã, por ser um verdadeiro exemplo de vida para mim. Agradeço ao meu tio, Pe. Ricardo Pereira Calvo, por ter acolhido a minha família, por ter garantido toda a minha educação, desde o ensino fundamental, nas melhores instituições. Tudo o que eu vier a fazer, não será suficiente por tudo aquilo que o senhor já fez e faz por mim.

Agradeço as minhas queridas irmãs, Lilica e Helô, que sempre estiveram ao meu lado em tudo que precisei e por serem exemplos de perseverança, carinho e amor. Agradeço aos meus queridos irmãos, Zé, por ser o vascaíno mais amado na minha vida, a certeza que a nossa relação ultrapassa as fronteiras jurídicas e ao $J P$, que junto com Jesus reza e torce por todos nós, pelo seu sorriso que iluminou e continuará iluminando a forma de enxergar a vida. Agradeço ao meu pai, pela sua maneira de nos amar.

Agradeço as minhas lindas sobrinhas, Fefe e Lulu, por me mostrarem, tenho cada vez mais certeza disto, que os seres humanos nunca deveriam crescer e que o mundo deveria ser governado por crianças como vocês. Agradeço a minha namorada, Linda, pelo seu apoio e carinho ao longo destes dois anos, sempre ao meu lado e da minha família no momento mais difícil que passamos, pela sua capacidade de ser uma verdadeira amiga.

Agradeço a minha orientadora, a professora Márcia Nina Bernardes, por ter aceito e pela ajuda em orientar este trabalho, com sugestões sempre 
valiosas. Agradeço, por fim, a todos (as) professores (as) que tive ao longo destes cinco anos, por compartilhar o conhecimento de vocês para a minha formação. 


\section{RESUMO}

O presente trabalho tem por objetivo discorrer sobre o dever de prevenção estabelecido pela Corte Interamericana de Direitos Humanos em determinados casos julgados pelo respectivo Tribunal. Neste caminho, encontramos 19 julgados envolvendo diferentes contextos de violações de direitos humanos, mas selecionamos apenas dez. $\mathrm{O}$ trabalho foi dividido em três capítulos. O primeiro deles teve por objetivo apresentar o Sistema Interamericano de Proteção dos Direitos Humanos e o papel da Corte Interamericana de Direitos Humanos. O segundo, teve o de demonstrar o conteúdo jurídico do artigo 1.1 da Convenção Americana de Direitos Humanos quanto as duas obrigações genéricas previstas, que são de respeito e garantia, e apresentar o conceito do dever de prevenção. No terceiro capítulo, o objetivo foi analisar o dever de prevenção com base nos dez casos selecionados. Na conclusão, apresentamos de forma crítica a maneira que a Corte Interamericana de Direitos Humanos desenvolveu o dever de prevenir ao longo dos julgados analisados e procuramos apresentar uma nova perspectiva acerca do citado dever.

Palavras-chave: Corte Interamericana de Direitos Humanos; obrigação de respeito e garantia; dever de prevenção. 


\section{SUMÁRIO}

INTRODUÇÃO

CAPÍTULO I: O SISTEMA INTERAMERICANO DE DIREITOS HUMANOS E A CORTE IDH ...................................................... 10

I.1 - O Sistema Interamericano de Direitos Humanos........................... 10

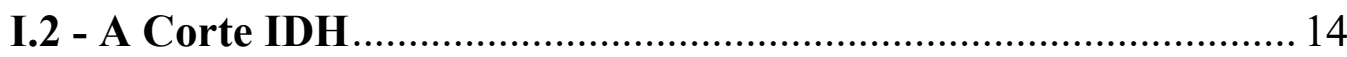

CAPÍTULO II: A OBRIGAÇÃO DE RESPEITAR E GARANTIR PREVISTA NO ARTIGO 1.1 DA CADH E O CONCEITO DO DEVER DE PREVENÇÃO

II.1 - A obrigação de respeitar e garantir prevista no artigo 1.1 da CADH 21

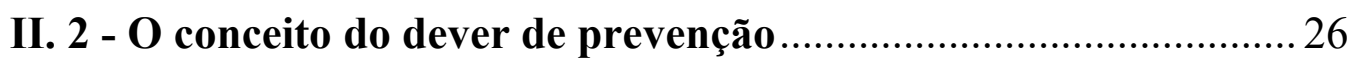

CAPÍTULO III: O DEVER DE PREVENÇÃo ATRAVÉS DOS

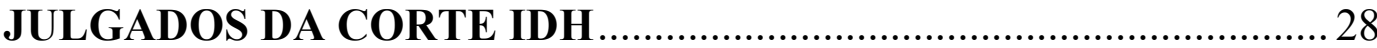

1 - Caso Masacre de Pueblo Bello vs. Colômbia: Sentença de 31 de janeiro de 2006........................................................................... 28

2 - Caso Comunidad Indígena Sawhoyamaxa Vs. Paraguai: Sentença

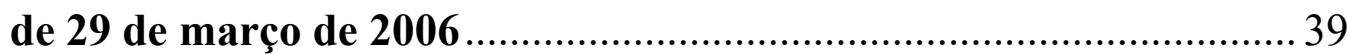

3 - Caso Ximenes Lopes Vs. Brasil: Sentença de 4 de julho de 2006.....47

4 - Caso Valle Jaramillo e Outros Vs. Colômbia: Sentença de 27 de

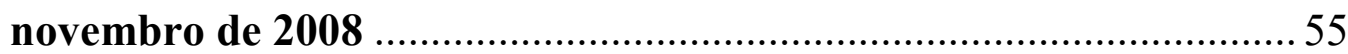

5 - Caso González e outras (“Campo Algodonero") Vs. México: Sentença de 16 de novembro de 2009 60

6 - Caso Pacheco Teruel e Outro Vs. Honduras: Sentença de 27 de abril de 2012

7 - Caso Vélez Restrepo e Familiares Vs. Colômbia: Sentença de 3 de

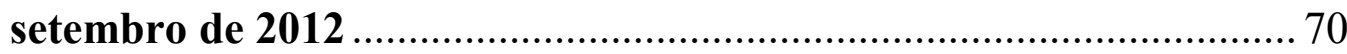

8 - Caso Castillo González e Outros Vs. Venezuela: Sentença de 27 de

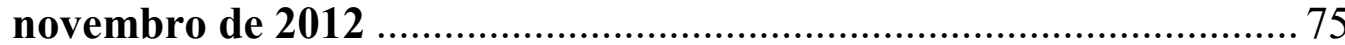

9 - Caso Hermanos Landaeta Mejías e Outros Vs. Venezuela: Sentença

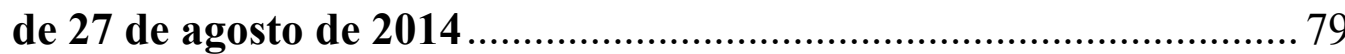

10 - Caso Rodríguez Vera e Outros (Desaparecidos do Palácio de Justiça) Vs. Colômbia: Sentença de 14 de novembro de 2014 ............ 86

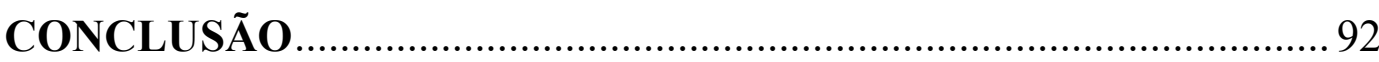

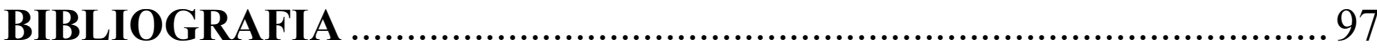




\section{LISTA DE ABREVIATURAS}

CADH - Convenção Americana de Direitos Humanos;

Comissão IDH - Comissão Interamericana de Direitos Humanos;

Corte IDH - Corte Interamericana de Direitos Humanos;

ELP - Exército de Libertação Popular;

M-19 - Movimento 19 de Abril;

OC - Opinião Consultiva;

OEA - Organização dos Estados Americanos;

SIDH - Sistema Interamericano de Direitos Humanos;

SUS - Sistema Único de Saúde;

FARC - Forças Revolucionárias da Colômbia. 


\section{INTRODUÇÃO}

O objeto do presente trabalho é discorrer sobre o dever de prevenção estabelecido pela Corte Interamericana de Direitos Humanos ("Corte IDH" ou "Corte Interamericana" ou "Tribunal") em determinados casos contenciosos julgados pelo respectivo tribunal. A escolha por esse objeto de pesquisa decorreu da nossa experiência prática em trabalhar, pelo período de três meses, no referido Tribunal internacional.

Em virtude desta vivência, tivemos a oportunidade de ajudar na elaboração da sentença de um importante caso histórico envolvendo a Colômbia, Rodríguez Vera y otros (Desaparecidos del Palacio de Justicia) que tratou, entre outras questões relevantes, exatamente acerca do dever de prevenção.

Além disto, a escolha do referido objeto tem importância prática porque explora quais são as hipóteses em que a Corte IDH considera violado o dever de prevenção. Conforme veremos, a princípio, seria apenas por atos cometidos por particulares que implicaria a responsabilidade estatal, mas perceberemos que, em certas situações, são os próprios agentes estatais os responsáveis. Sendo assim, tal constatação nos levará a uma importante reflexão quanto ao enquadramento da responsabilidade estatal frente ao artigo 1.1 da Convenção Americana, de forma mais específica frente as obrigações de respeitar e garantir.

Em busca de preencher o objeto desta monografia da forma mais completa possível, adotamos como método de pesquisa analisar todos os casos julgados pela Corte Interamericana pertinentes, exclusivamente, ao dever de prevenção, decorrente do artigo 1.1 da Convenção Americana de Direitos Humanos. Neste caminho, encontramos 19 julgados envolvendo diferentes contextos de violações de direitos humanos. Dos 19 casos encontrados, selecionamos apenas dez por duas razões. A primeira é que certos julgados apresentavam, apesar das diferenças fáticas, contextos semelhantes e os mesmos argumentos que outros; a segunda razão é que as 
demandas escolhidas trouxeram, no nosso entendimento, contribuições relevantes para o desenvolvimento do dever de prevenção.

Quanto à estrutura, o trabalho foi dividido em três capítulos. O primeiro deles teve por objetivo apresentar o chamado Sistema Interamericano de Proteção dos Direitos Humanos e o papel da Corte IDH neste cenário. O segundo, teve o de demonstrar o conteúdo jurídico do artigo 1.1 da Convenção Americana de Direitos Humanos quanto as duas obrigações genéricas previstas, que são de respeito e garantia, e apresentar o conceito do dever de prevenção.

No terceiro capítulo, o nosso principal objetivo foi analisar o dever de prevenção com base nos dez casos selecionados. Todos estão em ordem cronológica, do mais antigo ao mais recente, envolvendo os mais diferentes temas de direitos humanos (conflito armado, direitos dos indígenas, violência contra a mulher, entre outros).

De modo a facilitar o entendimento dos julgados expostos e, consequentemente, da posição adotada pelo Tribunal, em todos eles adotamos a seguinte estrutura: a) explicamos inicialmente a importância do julgado ter sido escolhido, depois b) fizemos um resumo do contexto histórico e dos fatos em que estão inseridos, passamos em seguida c) aos principais argumentos levantados pelas partes do processo - a Comissão Interamericana de Direitos Humanos, os representantes das vítimas e o Estado demandado -sobre o dever de prevenção, posteriormente d) a posição adotada pela Corte IDH e, no final de cada um deles e) tiramos algumas conclusões acerca do dever de prevenção.

Por fim, na conclusão, apresentaremos de forma crítica a maneira que a Corte IDH desenvolveu o dever de prevenir ao longo dos julgados analisados. Verificamos certos deslizes cometidos e procuramos apresentar uma nova perspectiva acerca do citado dever tanto em relação ao seu conceito quanto às obrigações de respeito e garantia em relação ao artigo 1.1 da Convenção Americana de Direitos Humanos. 


\section{CAPÍTULO I: O SISTEMA INTERAMERICANO DE DIREITOS HUMANOS E A CORTE IDH}

O presente capítulo tem dois objetivos que são i) apresentar o Sistema Interamericano de Direitos Humanos ("SIDH" ou "Sistema Interamericano"), para que o leitor tenha uma visão objetiva dos principais instrumentos internacionais e órgãos que compõem o referido sistema e ii) falar sobre o funcionamento de um destes órgãos que é a Corte IDH. Não sendo o principal escopo deste trabalho, vamos abordar este capítulo de forma resumida, sem maiores aprofundamentos.

\section{I.1 - O Sistema Interamericano de Direitos Humanos.}

O sistema internacional de proteção dos direitos humanos pode ser dividido em dois grupos quanto ao âmbito de sua aplicação. De um lado, existe o chamado sistema global que é formado por instrumentos internacionais que foram e são produzidos no campo de atuação das Nações Unidas $^{1}$. Por outro lado, existem também os sistemas regionais de proteção que, segundo a Flávia Piovesan, “[...] buscam internacionalizar os direitos humanos no plano regional, particularmente na Europa, América e África"². Tais sistemas são complementares ${ }^{3}$, mas para fins deste trabalho nos interessa o sistema regional da América.

\footnotetext{
${ }^{1}$ A título de exemplos existem os seguintes instrumentos das Nações Unidas: Declaração Universal de Direitos Humanos, Pacto Internacional dos Direitos Civis e Políticos, Pacto Internacional dos Direitos Econômicos, Sociais e Culturais, entre outros.

2 PIOVESAN, Flávia. Direitos Humanos e o direito constitucional internacional. 14 ed., rev. e atual. São Paulo: Saraiva, 2013, p. 339.

${ }^{3}$ PIOVESAN, Flávia. Introdução ao Sistema Interamericano de Proteção dos Direitos Humanos: A Convenção Americana de Direitos Humanos. In: O sistema de proteção dos direitos humanos e o direito brasileiro. Coordenação Luiz Flávio Gomes, Flávia Piovesan. São Paulo: Editora Revista dos Tribunais, 2000, p. 24.
} 
O SIDH, que corresponde a proteção de direitos humanos nos Estadosmembros da Organização dos Estados Americanos ${ }^{4}$ (“OEA”) ${ }^{5}$, teve seu início, formalmente, com a aprovação da Declaração Americana dos Direitos e Deveres do Homem ("Declaração Americana" ou "Declaração") que foi adotada em 02 de maio de 1948 durante a Nona Conferencia Internacional Americana realizada na cidade de Bogotá, na Colômbia ${ }^{6}$. A Declaração Americana é o primeiro instrumento internacional de direitos humanos de caráter geral.

Em seu texto, a Declaração Americana apresenta 38 artigos que definem os direitos ${ }^{7}$ protegidos e os deveres ${ }^{8}$ atribuídos aos indivíduos. Estão incluídos direitos civis, políticos, econômicos, sociais e culturais.

Um ponto importante que merece destaque é que a Corte Interamericana estabeleceu que a Declaração Americana, mesmo não sendo esta um tratado internacional, constitui fonte de obrigação para os Estadosmembros da OEA. Este posicionamento da Corte IDH foi explicitado na Opinião Consultiva - $n^{\circ} 10 / 1989^{9}$.

Outra observação que deve ser destacada é que a Declaração Americana é a base normativa dos direitos humanos para os Estadosmembros da OEA que não ratificaram a Convenção Americana sobre Direitos Humanos ${ }^{10}$. Neste caso, o órgão responsável pela aplicação da

\footnotetext{
${ }^{4}$ A Organização dos Estados Americanos é uma organização intergovernamental regional que compreende 35 Estados-membros. O instrumento constitutivo da OEA é a Carta da OEA que é um tratado multilateral adotado em 1948, entrou em vigor em dezembro de 1951.

${ }^{5}$ GOMES, Luiz Flávio e MAZZUOLI, Valerio de Oliveira. Comentários à Convenção Americana sobre Direitos Humanos: Pacto de San José da Costa Rica. 4.ed. ver., atual.e ampl. São Paulo: Editora Revista dos Tribunais, 2013, p. 16.

${ }^{6}$ Corte IDH. Corte Interamericana de Derechos Humanos. Documentos Básicos em materia de derechos humanos en el sistema interamericano, 2012, p. 04.

${ }^{7} \mathrm{O}$ rol de direitos está previsto no capítulo primeiro da Declaração Americana, estando distribuídos em vinte e oito artigos.

${ }^{8} \mathrm{O}$ rol de deveres está previsto no capítulo segundo da Declaração Americana, estando distribuídos em dez artigos.

${ }^{9}$ CORTE IDH. Interpretação da Declaração Americana dos Direitos e Deveres do Homem no Marco do Artículo 64 da Convenção Americana sobre Direitos Humanos. Opinião Consultiva OC10/89 de 14 de julho de 1989. Serie A No. 10, parágrafos 35-45. Mais adiante iremos explicar o que são opiniões consultivas.

${ }^{10}$ GOMES, Luiz Flávio e MAZZUOLI, Valerio de Oliveira. Comentários à Convenção Americana sobre Direitos Humanos: Pacto de San José da Costa Rica. 4.ed. ver., atual.e ampl. São Paulo: Editora Revista dos Tribunais, 2013, p. 17.
} 
Declaração é a Comissão Interamericana de Direitos Humanos ("Comissão IDH" ou "Comissão") $)^{11}$.

Ao lado da Declaração Americana existe um outro principal instrumento regional de proteção e promoção dos direitos humanos na América, é a Convenção Americana sobre Direitos Humanos ("CADH” ou “Convenção Americana”), mais conhecida também como Pacto de São José da Costa Rica.

A CADH foi adotada em 22 de novembro de 1969, entrando em vigor em 18 de julho de 1978. Em relação à estrutura, a Convenção Americana está dividida em três partes. Na primeira, o seu texto trata sobre os deveres impostos aos Estados-partes e os direitos protegidos ${ }^{12}$; na segunda versa sobre os meios de proteção de se alcançar a proteção dos direitos previstos na primeira parte ${ }^{13}$; na última, trata sobre às disposições gerais e transitórias ${ }^{14}$.

No que se refere à segunda parte, a CADH confere a dois órgãos a competência para conhecer os assuntos relacionados com o cumprimento dos compromissos assumidos pelos Estados-parte da Convenção ${ }^{15}$. Estes dois órgãos são a Comissão Interamericana e a Corte IDH.

Quanto a fonte de obrigação para os Estados-membros da OEA, a CADH poderá ser utilizada em duas situações. Na primeira, a Convenção

\footnotetext{
${ }^{11}$ A Comissão IDH é um órgão autônomo da OEA responsável pela promoção e proteção de direitos humanos no continente americano. A Comissão foi criada em 1959.

${ }^{12}$ Os direitos protegidos pela CADH são os seguintes: direito ao reconhecimento da personalidade jurídica; direito à vida; direito à integridade pessoal; proibição da escravidão e da servidão; direito à liberdade pessoal; princípio da legalidade e da retroatividade; direito à indenização; proteção da honra e da dignidade; liberdade de consciência e de religião; liberdade de pensamento e de expressão; direito de retificação ou resposta; direito de reunião; liberdade de associação; proteção à família; direito ao nome; direitos da criança; direito à nacionalidade; direito à propriedade privada; direito de circulação e de residência; direitos políticos; igualdade perante a lei; proteção judicial e desenvolvimento progressivo dos direitos econômicos, sociais e culturais.

${ }^{13}$ A segunda parte está compreendida entre os artigos 33 e 73 da CADH.

${ }^{14}$ A terceira parte está compreendida ente os artigos 74 e 82 da CADH.

${ }^{15} \mathrm{O}$ artigo 33 da CADH estabelece o seguinte: "São competentes para conhecer dos assuntos relacionados com o cumprimento dos compromissos assumidos pelos Estados partes nesta Convenção:

a. a Comissão Interamericana de Direitos Humanos, doravante denominada a

Comissão; e

b. a Corte Interamericana de Direitos Humanos, doravante denominada a

Corte".
} 
será utilizada como fonte para os Estados-partes, mas que não aceitaram a competência contenciosa da Corte Interamericana. Neste caso, a Comissão será o órgão competente para se valer do referido tratado internacional.

$\mathrm{Na}$ segunda situação, a Convenção Americana será fonte para os Estados-partes que aceitaram a competência contenciosa da Corte IDH. Neste caso, tanto a Comissão quanto a Corte Interamericana poderão determinar se houve ou não alguma violação aos deveres e direitos previstos na $\mathrm{CADH}$.

Com base no que foi explicitado até agora, tomando como referência a classificação elaborada por Claudia Martin e Diego Rodríguez Pinzón ${ }^{16}$, podemos dizer que o sistema interamericano compreende um regime complexo de adesão, estando dividido em três níveis:

i) Nível mínimo de adesão: é aplicável quanto ao cumprimento das obrigações da Declaração Americana, é exigido a todos os Estados-membros da OEA, sendo a Comissão IDH responsável pela supervisão;

ii) Segundo nível de adesão: é aplicável aos Estados que ratificaram a $\mathrm{CADH}$, mas que não aceitaram a competência contenciosa da Corte IDH. Estes Estados devem cumprir com as obrigações emanadas da $\mathrm{CADH}$, porém não estão sujeitos a decisões da Corte, apenas da Comissão;

iii) Nível máximo de adesão: é aplicável aos Estados que aceitaram a competência contenciosa da Corte. Estes Estados devem cumprir com as obrigações emanadas da $\mathrm{CADH}$ e podem ser sujeitos das decisões obrigatórias da Corte Interamericana.

\footnotetext{
${ }^{16}$ MARTIN, Claudia e PINZÓN, Diego Rodríguez. La prohibición de la tortura y los malos tratos en el sistema interamericano: manual para víctimas y sus defensores. Serie de Manuales de la OMCT Vol.2, 2006, p. 31.
} 
Retomando os instrumentos que formam o SIDH, a CADH tem dois protocolos adicionais ${ }^{17}$. Um deles é o Protocolo Adicional à Convenção Americana sobre Direitos Humanos em Matéria de Direitos Econômicos, Sociais e Culturais, também conhecido como "Protocolo de San Salvador" que foi adotado em 17 de novembro de 1988 ${ }^{18}$; o segundo é o Protocolo Adicional à Convenção Americana sobre Direitos Humanos referente à Abolição da Pena de Morte, que foi adotado em 08 de junho de $1990^{19}$.

Além destes protocolos adicionais existem outros instrumentos internacionais que fazem parte do SIDH. São eles: Convenção Interamericana para Prevenir, Sancionar e Punir a Tortura (1985); Convenção Interamericana sobre Desaparecimento Forçado de Pessoas (1994); Convenção Interamericana para Eliminação de todas as Formas de Descriminação contra as Pessoas com Deficiência (1999); Declaração de Princípios sobre a Liberdade de Expressão (2000); Carta Democrática Interamericana (2001); Princípios e Boas Práticas sobre a Proteção das Pessoas Privadas de Liberdade nas Américas (2008); Convenção Interamericana contra o Racismo, a Discriminação Racial e Formas Conexas de Intolerância (2013); Convenção Interamericana contra todo Forma de Discriminação e Intolerância (2013).

Passaremos agora para análise do Tribunal interamericano, iremos abordar a natureza, o regime jurídico, o objetivo, a competência e as suas funções.

\section{I.2 - A Corte IDH.}

\footnotetext{
17 O artigo 77.1 da Convenção Americana prevê a possibilidade de qualquer Estado-parte e a Comissão IDH apresentarem projetos de protocolos adicionais à $\mathrm{CADH}$, "com a finalidade de incluir progressivamente, no regime de proteção da mesma, outros direitos e liberdades".

${ }^{18}$ Necessário registrar que em recente caso julgado deste ano, 01 de setembro a Corte Interamericana pela primeira vez aplicou o referido protocolo. O caso foi Gonzales Lluy y Otros vs. Ecuador e o Tribunal entendeu pela violação ao artigo 13 (direito à educação) do protocolo.

${ }^{19}$ Cabe registrar que, segundo o artigo 77.2 da $\mathrm{CADH}$, o protocolo é aplicado somente entre os Estados-partes no mesmo.
} 
O Tribunal foi formalmente estabelecido em 3 de setembro de 1979, em decorrência da entrada em vigor da CADH em 18 de julho de 1978. Tratase de uma instituição de natureza jurisdicional cujo objetivo primordial é aplicar e interpretar a CADH, conforme dispõe o art. $1^{\circ}$ do Estatuto do próprio Tribunal ${ }^{20}$. Quanto ao regime jurídico, a Corte IDH exerce suas funções de acordo com as disposições da CADH e também do seu regulamento interno.

Um ponto importante é que a Corte IDH, diferentemente da Comissão, não é um órgão da OEA, mas sim uma instituição própria da Convenção Americana $^{21}$. O Tribunal tem autonomia no exercício de sua competência jurisdicional a qual está distribuída em duas funções: i) consultiva e ii) contenciosa. Vamos analisar cada uma delas.

$\mathrm{Na}$ função consultiva, "a Corte interpreta o direito internacional sem analisar a ocorrência de fatos específicos (concretos) "22. Neste plano consultivo, qualquer membro da $\mathrm{OEA}$, podendo ser parte ou não da $\mathrm{CADH}$, pode solicitar uma opinião da Corte IDH acerca da interpretação da própria Convenção ou de qualquer outro tratado relativo à proteção dos direitos humanos nos Estados americanos ${ }^{23}$ ou até mesmo da interpretação de leis internas $^{24}$. Esta atribuição é regida pelo art. 64 da $\mathrm{CADH}^{25}$.

\footnotetext{
20 "Artigo $1^{\circ}$. Natureza e regime jurídico. A Corte Interamericana de Direitos humanos é uma instituição judiciária autônoma cujo objetivo é a aplicação e a interpretação da Convenção Americana sobre Direitos Humanos. A Corte exerce suas funções em conformidade com as disposições da citada Convenção e deste Estatuto."

${ }^{21}$ GOMES, Luiz Flávio e MAZZUOLI, Valerio de Oliveira. Comentários à Convenção Americana sobre Direitos Humanos: Pacto de San José da Costa Rica. 4.ed. ver., atual.e ampl. São Paulo: Editora Revista dos Tribunais, 2013, p. 254.

${ }^{22}$ GOMES, Luiz Flávio e MAZZUOLI, Valerio de Oliveira. Comentários à Convenção Americana sobre Direitos Humanos: Pacto de San José da Costa Rica. 4.ed. ver., atual.e ampl. São Paulo: Editora Revista dos Tribunais, 2013, p. 254.

${ }^{23}$ PIOVESAN, Flávia. Introdução ao Sistema Interamericano de Proteção dos Direitos Humanos: A Convenção Americana de Direitos Humanos. In: $O$ sistema de proteção dos direitos humanos e o direito brasileiro. Coordenação Luiz Flávio Gomes, Flávia Piovesan. São Paulo: Editora Revista dos Tribunais, 2000, p. 43 e 44.

${ }^{24}$ Todas estas solicitudes de OC estão previstas nos arts. 70, 71 e 72 do Regulamento Interno da Corte IDH.

${ }^{25} \mathrm{O}$ art. 64 prevê o seguinte: "1. Os Estados membros da Organização poderão consultar a Corte sobre a interpretação desta Convenção ou de outros tratados concernentes à proteção dos direitos humanos nos Estados americanos. Também poderão consultá-la, no que lhes compete, os órgãos enumerados no capítulo X da Carta da Organização dos Estados Americanos, reformada pelo Protocolo de Buenos Aires. 2. A Corte, a pedido de um Estado membro da Organização, poderá
} 
Nesta função, a Corte IDH emite um parecer em um documento chamado "Opinião Consultiva" (OC- número/ano) ${ }^{26}$. Na primeira $\mathrm{OC}-\mathrm{n}^{\mathrm{o}}$ 1/1982, o Tribunal foi provocado pelo Governo peruano para saber como deveria ser interpretado a frase "outros tratados concernentes à proteção dos direitos humanos nos Estados americanos" prevista no art. 64 da CADH.

No parecer elaborado, a Corte Interamericana determinou que a sua função consultiva pode ser sobre toda disposição concernente à proteção dos direitos humanos de qualquer tratado internacional aplicável nos Estados americanos, seja bilateral ou multilateral, não importando de quem seja ou possa ser parte no mesmo ${ }^{27}$.

Além disto, nesta mesma OC, a Corte considerou que os tratados internacionais não precisavam ser necessariamente firmados entre Estados americanos, bastando que o objeto deles seja acerca da proteção de direitos humanos nos Estados americanos ${ }^{28}$.

Necessário destacar que a opiniões consultivas, não obstante não serem vinculante aos Estados-partes, "contribuíram para a interpretação e consequente ampliação de alguns direitos consagrados na Convenção Americana sobre Direitos Humanos" ${ }^{29}$. Neste sentido, a própria Corte IDH já assinalou que o objetivo das opiniões consultivas é

43. [...] destinado a ayudar a los Estados y órganos a cumplir y a aplicar tratados en materia de derechos humanos, sin someterlos alformalismo y al sistema de sanciones que caracteriza el proceso contencioso ${ }^{30}$.

emitir pareceres sobre a compatibilidade entre qualquer de suas leis internas e os mencionados instrumentos internacionais."

${ }^{26}$ Até a finalização deste trabalho, a Corte já tinha emitido 21 opiniões consultivas. Todas estão disponíveis no link: http://www.corteidh.or.cr/cf/Jurisprudencia2/busqueda_opiniones_consultivas.cfm?lang=es

${ }^{27}$ CORTE IDH. "Outros Tratados" Objeto da Função Consultiva da Corte (art. 64 Convenção Americana sobre Direitos Humanos). Opinião Consultiva OC-1/82 de 24 de setembro de 1982. Serie A No. 1, parágrafo 52.

${ }^{28}$ CORTE IDH. "Outros Tratados" Objeto da Função Consultiva da Corte (art. 64 Convenção Americana sobre Direitos Humanos). Opinião Consultiva OC-1/82 de 24 de setembro de 1982. Serie A No. 1, parágrafo 18-19.

${ }^{29}$ PIOVESAN, Flávia. Introdução ao Sistema Interamericano de Proteção dos Direitos Humanos: A Convenção Americana de Direitos Humanos. In: O sistema de proteção dos direitos humanos e o direito brasileiro. Coordenação Luiz Flávio Gomes, Flávia Piovesan. São Paulo: Editora Revista dos Tribunais, 2000, p. 45.

${ }^{30}$ CORTE IDH. Restrições à Pena de Morte (Arts. 4.2 y 4.4 Convenção Americana sobre Direitos Humanos). Opinião Consultiva OC-3/83 del 8 de setembro de 1983. Serie A No. 3, parágrafo 43. 
Quanto à função contenciosa, que nos interessa mais propriamente, a Corte IDH irá decidir um caso submetido a sua jurisdição para determinar se houve ou não alguma violação a direito ou liberdade previsto não apenas na $\mathrm{CADH}$, mas também em outros tratados de direitos humanos aplicáveis ao SIDH já mencionados.

Um ponto a ressaltar é que apenas os Estados-partes da CADH e a Comissão IDH têm o direito de submeter um caso para decisão do Tribunal ${ }^{31}$. Além disto, o Estado-parte demandado tem que ter aceito a competência contenciosa da Corte $\mathrm{IDH}^{32}$, afinal trata-se de uma cláusula facultativa conferida aos Estados americanos prevista no artigo 62 da $\mathrm{CADH}^{33}$.

A Comissão IDH, ao submeter um caso, deve informar as razões que a motivaram levar a demanda para a Corte Interamericana. Outrossim, tanto a Comissão IDH quanto os Estados-partes devem indicar as pretensões, incluídas as reparações e custas, que entendem cabíveis contra o Estado demandado ${ }^{34}$.

A decisão da Corte Interamericana é vinculante ao Estado-parte. Segundo Flávia Piovesan,

"A decisão da Corte tem força vinculante e obrigatória, cabendo ao Estado seu imediato cumprimento. Se a Corte fixar uma compensação à vítima, a decisão valerá como título executivo, em conformidade com os procedimentos internos relativos à execução de sentença desfavorável ao Estado" ${ }^{35}$.

\footnotetext{
${ }^{31}$ Esta limitação está prevista no artigo 61.1 da CADH que assim estabelece "Artigo 61: 1. Somente os Estados partes e a Comissão têm direito de submeter caso à decisão da Corte."

32 Dos 35 Estados que conformam a OEA, 21 reconheceram a competência contenciosa da Corte. Esses Estados são: Argentina, Barbados, Bolívia, Brasil, Chile, Colômbia, Costa Rica, Equador, El Salvador, Guatemala, Haiti, Honduras, México, Nicarágua, Panamá, Paraguai, Peru, República Dominicana, Suriname, Uruguai.

${ }^{33} \mathrm{O}$ art. 62 da CADH estabelece o seguinte: "1. Todo Estado parte pode, no momento do depósito do seu instrumento de ratificação desta Convenção ou de adesão a ela, ou em qualquer momento posterior, declarar que reconhece como obrigatória, de pleno direito e sem convenção especial, a competência da Corte em todos os casos relativos à interpretação ou aplicação desta Convenção. 2. A declaração pode ser feita incondicionalmente, ou sob condição de reciprocidade, por prazo determinado ou para casos específicos. Deverá ser apresentada ao Secretário-Geral da Organização, que encaminhará cópias da mesma aos outros Estados membros da Organização e ao Secretário da Corte. 3. A Corte tem competência para conhecer de qualquer caso relativo à interpretação e aplicação das disposições desta Convenção que lhe seja submetido, desde que os Estados partes no caso tenham reconhecido ou reconheçam a referida competência, seja por declaração especial, como preveem os incisos anteriores, seja por convenção especial."

${ }^{34}$ Estes pressupostos estão previstos nos artigos 35 e 36 do Regulamento da Corte IDH.

${ }^{35}$ PIOVESAN, Flávia. Introdução ao Sistema Interamericano de Proteção dos Direitos Humanos: A Convenção Americana de Direitos Humanos. In: O sistema de proteção dos direitos humanos e o
} 
Segundo Cançado Trindade, ao comentar as decisões dos tribunais internacionais em geral, os Estados devem adotar procedimentos de direito interno para assegurar, em base permanente, o fiel cumprimento das referidas sentenças dos tribunais internacionais ${ }^{36}$. Além disto, ele considera que o cumprimento das sentenças deve ser integral, sem lugar para considerações de cunho pragmático ${ }^{37}$.

Uma resposta positiva à indagação pode ser fundamentada na própria $\mathrm{CADH}$ que determina no seu artigo 68.1 que "Os Estados-partes na Convenção comprometem-se a cumprir a decisão da Corte em todo caso em que forem partes". Outro fundamento pode ser extraído da Convenção de Viena sobre o Direito dos Tratados (1969) no seu artigo 26 ao estabelecer que "Todo tratado em vigor obriga as partes e deve ser cumprido por elas de boa fé", é o conhecido princípio do pacta sunt servanda.

Um aspecto interessante quanto ao cumprimento pelos Estados-partes das decisões proferidas pela Corte foi a adoção da chamada supervisão de sentença, que também está incluída na função contenciosa exercida pelo Tribunal. O precedente que estabeleceu a criação de um mecanismo de supervisão de sentença ocorreu no caso Baena Ricardo e Outros vs. Panamá $^{38}$. Nesta demanda, o Tribunal Interamericano declarou o seguinte:

72. Una vez determinada la responsabilidad internacional del Estado por la violación de la Convención Americana, la Corte procede a ordenar las medidas destinadas a reparar dicha violación. La jurisdicción comprende la facultad de administrar justicia; no se limita a declarar el derecho, sino que también compreende la supervisión del cumplimiento de lo juzgado. Es por ello necesario establecer y poner en funcionamiento mecanismos o procedimientos para la supervisión del cumplimiento de las decisiones judiciales, actividad que es inherente a la función jurisdiccional. La supervisión del cumplimiento de las sentencias es uno de los elementos que componen la jurisdicción. Sostener lo

direito brasileiro. Coordenação Luiz Flávio Gomes, Flávia Piovesan. São Paulo: Editora Revista dos Tribunais, 2000, p. 45.

${ }^{36}$ TRINDADE, Antônio Augusto Cançado. Os tribunais internacionais contemporâneos. Brasília: FUNAG, 2013, p. 64.

${ }^{37}$ TRINDADE, Antônio Augusto Cançado. Os tribunais internacionais contemporâneos. Brasília: FUNAG, 2013, p. 64.

${ }^{38}$ CORTE IDH. Caso Baena Ricardo e Outros Vs. Panamá. Competência. Sentença de 28 de novembro de 2003. Serie C No. 104, parágrafos, 72-74. 
contrario significaría afirmar que las sentencias emitidas por la Corte son meramente declarativas y no efectivas. El cumplimiento de las reparaciones ordenadas por el Tribunal en sus decisiones es la materialización de la justicia para el caso concreto y, por ende, de la jurisdicción; en caso contrario se estaría atentando contra la raison d'être de la operación del Tribunal.

73. La efectividad de las sentencias depende de su ejecución. El proceso debe tender a la materialización de la protección del derecho reconocido en el pronunciamiento judicial mediante la aplicación idónea de dicho pronunciamiento. 74. El cumplimiento de las sentencias está fuertemente ligado al derecho de acceso a la justicia, el cual se encuentra consagrado en los artículos 8 (Garantías Judiciales) y 25 (Protección Judicial) de la Convención Americana ${ }^{39}$. (Grifos nosso).

A supervisão de cumprimento das sentenças consiste na solicitação periódica de informações ao Estado-parte condenado sobre as medidas adotadas para efeitos de cumprimento e também as observações enviadas pela Corte, das vítimas e de seus representantes. Ao dispor de todas informações necessárias, a Corte IDH pode avaliar se houve ou não o cumprimento total das medidas previstas na decisão. A Corte Interamericana mantém aberta a supervisão dos casos até que considere que haja um total cumprimento ${ }^{40}$

Qual é a importância da Corte IDH ao proferir as sentenças? As sentenças são as principais fontes, ao lado da $\mathrm{CADH}$, de obrigações para os Estados-partes porque é com base em interpretações diante de casos concretos que o Tribunal aplica o conteúdo dos diretos humanos na região, servindo como parâmetro tanto para os países quanto para o próprio Tribunal, que sempre faz referência aos seus julgados.

Tendo sido atendidos os objetivos propostos deste capítulo, podemos concluir que (i) o SIDH é um sistema regional de proteção e promoção de direitos humanos, sendo a Declaração Americana e a CADH os principias instrumentos internacionais que são as fontes de obrigações para os Estadosmembros da OEA; (ii) os dois órgãos responsáveis pela promoção dos direitos humanos na região são a Comissão IDH e a Corte IDH, em especial

\footnotetext{
${ }^{39}$ CORTE IDH. Caso Baena Ricardo e Outros Vs. Panamá. Competência. Sentença de 28 de novembro de 2003. Serie C No. 104, parágrafos, 72-74.

40 Corte IDH. Relatório Anual de 2012. Disponível no link: http://www.corteidh.or.cr/sitios/informes/docs/POR/por_2012.pdf
} 
para verificar o cumprimento dos compromissos assumidos pelos Estadospartes da Convenção Americana; (iii) todos os Estados-membros da OEA devem cumprir a com a Declaração Americana, e todos os Estados-partes da $\mathrm{CADH}$ devem cumprir com a Declaração e a $\mathrm{CADH}$; (iv) os Estados que aceitaram a competência contenciosa da Corte IDH devem cumprir com a Declaração, com a CADH e com as sentencias proferidas pela Corte Interamericana; (v) a Corte IDH é um órgão jurisdicional autônomo da CADH que exerce função consultiva e contenciosa e que (vi) as sentenças proferidas pela Corte são vinculantes frente aos Estados-partes que aceitaram sua competência jurisdicional.

Com o objetivo de explorar de forma mais precisa um dos principais instrumentos jurídicos do SIDH e um dos seus órgãos - a Corte IDH, no próximo capítulo iremos abordar o artigo 1.1 da Convenção Americana no que se refere as duas obrigações gerais previstas e a relação de cada uma delas com o dever de prevenção a partir do primeiro caso julgado pela Corte IDH. 


\section{CAPÍTULO II: A OBRIGAÇÃO DE RESPEITAR E GARANTIR PREVISTA NO ARTIGO 1.1 DA CADH E O CONCEITO DO DEVER DE PREVENÇÃO.}

Este capítulo tem por objetivo i) demonstrar a importância das obrigações de respeitar e garantir previstas no artigo 1.1 da Convenção Americana e ii) dar início a análise do dever de prevenção, apresentando a relação deste dever com o mencionado dispositivo e o seu conceito.

\section{II.1 - A obrigação de respeitar e garantir prevista no artigo 1.1 da} CADH.

A Convenção Americana possui 82 artigos que estão distribuídos em três partes conforme mencionado no primeiro capítulo deste trabalho. Dentre estes dispositivos, se pudéssemos eleger um que representa o núcleo dos direitos e liberdades previsto no texto da $\mathrm{CADH}$, este seria, sem dúvidas, o 1.1 .

Nas palavras de Eduardo Ferrer Mac-Gregor e de Carlos María Pelayo Möller, que sintetizaram muito bem a importância do referido dispositivo,

\footnotetext{
"El artículo $1^{\circ}$ de la Convención Americana sobre derechos humanos es la piedra angular sobre la cual descansa el sistema de derechos y libertades de dicho instrumento y, en gran medida, el Sistema Interamericano de Protección de los derechos humanos" ${ }^{\prime 1}$
}

A construção jurisprudencial desta pedra angular teve origem no primeiro caso contencioso julgado pela Corte Interamericana, Velásquez Rodríguez vs. Honduras, quando o Tribunal estabeleceu importantes

\footnotetext{
${ }^{41}$ MAC-GREGOR, Eduardo Ferrer e PELAYO MÕLLER, Carlos María. "La obligación de 'respetar' y 'garantizar' los derechos humanos a la luz de la jurisprudencia de la Corte Interamericana". In: Estudios Constitucionales, Año 10, No 2 2012, pp. 141. Disponível em: http://www.cecoch.cl/docs/pdf/revista_10_2_2012/la_obligacion_Eduardo\%20Ferrer_Carlos_Pela yo.pdf Acesso em 29 de outubro de 2015.
} 
elementos ${ }^{42}$ para conduzir à análise da responsabilidade dos Estados-Partes frente ao texto da Convenção Americana, os quais são reiterados em quase todos os casos contenciosos já julgados pela Corte IDH. Necessário destacar que foi o próprio Tribunal que suscitou o artigo 1.1 no caso, com fundamento no princípio iura novit curia. A Comissão IDH não o considerou de maneira expressa a sua violação ao apresentar a demanda ${ }^{43}$.

$\mathrm{O}$ artigo 1.1 da CADH traz em seu conteúdo jurídico o seguinte texto:

Artigo $1^{\circ}$ Obrigação de Respeitar os Direitos

1. Os Estados Partes nesta Convenção comprometem-se a respeitar os direitos e liberdades nela reconhecidos e a garantir seu livre e pleno exercício a toda pessoa que esteja sujeita à sua jurisdição, sem discriminação alguma por motivo de raça, cor, sexo, idioma, religião, opiniões políticas ou de qualquer outra natureza, origem nacional ou social, posição econômica, nascimento ou qualquer outra condição social. (Grifos nosso)

Um destes elementos desenvolvidos pela Corte Interamericana foi considerar uma estreita relação entre o artigo 1.1 e cada um dos direitos protegidos pela $\mathrm{CADH}$, estabelecendo que qualquer violação atentatória a estes direitos implica, necessariamente, a violação do artigo 1.1 também $^{44}$. Indo mais além, a Corte IDH considerou que o artigo 1.1 é fundamental para determinar se uma violação dos direitos humanos reconhecidos pela Convenção pode ser atribuída a um Estado Parte ${ }^{45}$.

Ainda interpretando o dispositivo em tela, o Tribunal estabeleceu as duas obrigações gerais que estão previstas no próprio artigo 1.1 da $\mathrm{CADH}$, a obrigação de respeitar e de garantir. A primeira obrigação assumida é a de respeitar os direitos e liberdades reconhecidos na Convenção. Esta obrigação

\footnotetext{
${ }^{42}$ Apenas para não ficar muito genérico e abstrata a palavra elementos, a Corte no caso Velásquez Rodríguez vs. Honduras estabeleceu, por exemplo, parâmetros para a questão das exceções preliminares interpostas pelos Estados-partes, desenvolvendo o conceito do que é um recurso efetivo e adequado; os critérios de apreciação da prova (ônus e valor probatório); critérios para enquadrar um crime de desaparecimento forçado; desenvolvimento do artigo $2^{\circ}$ da CADH que trata do dever de adotar disposições do Direito interno por parte dos Estados-partes.

${ }^{43}$ CORTE IDH. Caso Velásquez Rodríguez Vs. Honduras. Mérito. Sentença de 29 de julho de 1988. Serie C No. 4, parágrafo 163.

${ }^{44}$ CORTE IDH. Caso Velásquez Rodríguez Vs. Honduras. Mérito. Sentença de 29 de julho de 1988. Serie C No. 4, parágrafo 162.

${ }^{45}$ CORTE IDH. Caso Velásquez Rodríguez Vs. Honduras. Mérito. Sentença de 29 de julho de 1988. Serie C No. 4, parágrafo 164.
} 
de respeito está direcionada para a atuação estatal no sentido de que os direitos e liberdades garantidos aos cidadãos representam um limite de atuação do Estado, com fundamento na pessoa humana.

Nas palavras da própria Corte IDH, “O exercício da função pública tem limites que derivam de que os direitos humanos são atributos inerentes à dignidade humana e, em consequência, superiores ao poder do Estado" ${ }^{46}$.

Esta obrigação de respeitar é um dos pilares do direito internacional dos direitos humanos, porque representa uma das principais características, decorrente da internacionalização dos direitos humanos, que é a condição do indivíduo ser sujeito de direitos na esfera internacional ${ }^{47}$.

Esta obrigação estatal simboliza o avanço da humanidade no processo de internacionalização dos direitos humanos, uma vez que a proteção dos direitos fundamentais transitou da órbita nacional para a internacional e a regional dos direitos humanos ${ }^{48}$. Neste sentido, a obrigação de respeitar está presente também na Convenção Europeia de Direitos Humanos, vejamos

\section{Convenção Europeia de Direitos Humanos:}

Artigo $1^{\circ}$. Obrigação de respeitar os direitos do homem

As Altas Partes Contratantes reconhecem a qualquer pessoa dependente da sua jurisdição os direitos e liberdades definidos no título I da presente Convenção.

Diante disto, esta obrigação, prevista no artigo 1.1 da CADH, implica em um dever de cunho negativo por parte dos Estados-Partes ${ }^{49}$. Caso contrário, em toda circunstância na qual um órgão ou funcionário do Estado ou de uma instituição de caráter público lese indevidamente um direito, se

\footnotetext{
${ }^{46}$ CORTE IDH. Caso Velásquez Rodríguez Vs. Honduras. Mérito. Sentença de 29 de julho de 1988. Serie C No. 4, parágrafo 165.

${ }^{47}$ PIOVESAN, Flávia. Introdução ao Sistema Interamericano de Proteção dos Direitos Humanos: A Convenção Americana de Direitos Humanos. In: O sistema de proteção dos direitos humanos e o direito brasileiro. Coordenação Luiz Flávio Gomes, Flávia Piovesan. São Paulo: Editora Revista dos Tribunais, 2000, p. 19.

${ }^{48}$ CASTAÑEDA, Mireya. El Derecho Internacional de los Derechos Humanos y su recepción nacional. Comisión Nacional de los Derchos Humanos. México, 2012, p. 24.

${ }^{49}$ GOMES, Luiz Flávio e MAZZUOLI, Valerio de Oliveira. Comentários à Convenção Americana sobre Direitos Humanos: Pacto de San José da Costa Rica. 4.ed. rev., atual.e ampl. São Paulo: Editora Revista dos Tribunais, 2013, p. 27.
} 
está perante uma hipótese de inobservância do dever de respeito consagrado nesse $\operatorname{artigo}{ }^{50}$.

Uma observação interessante acerca do dever de respeitar é feita por Valerio de Oliveira Mazzuoli ao dizer que:

\begin{abstract}
"Assim, um Estado-parte da Convenção Americana deve respeitar os direitos e liberdades nela reconhecidos independentemente de outro Estado-parte respeitálos ou não em relação às pessoas sujeitas à sua jurisdição. Daí a conclusão de ser objetiva a natureza da obrigação internacional relativa a direitos humanos" ${ }^{51}$
\end{abstract}

Em suma, quanto ao dever de respeito, podemos dizer que "La obligación de respeto consiste en cumplir directamente la conducta establecida en cada norma convencional, ya sea absteniéndose de actuar o dando una prestación" 52 .

Além da obrigação de respeitar, o artigo 1.1 da Convenção Americana também prevê outra obrigação para os Estados-Partes, trata-se da obrigação de garantir o livre e pleno exercício dos direitos reconhecidos na $\mathrm{CADH}$ a toda pessoa sujeita à sua jurisdição ${ }^{53}$. Mais precisamente consiste no dever que os Estados têm de organizar todo o aparato governamental e, em geral, todas as estruturas através das quais se manifesta o exercício do poder público, de maneira tal que sejam capazes de assegurar juridicamente o livre e pleno exercício dos direitos humanos ${ }^{54}$.

Segundo a Corte IDH, a obrigação de garantir implica que os Estados devem prevenir, investigar e punir toda violação dos direitos reconhecidos pela Convenção e procurar, ademais, o restabelecimento, se possível, do

\footnotetext{
${ }^{50}$ CORTE IDH. Caso Velásquez Rodríguez Vs. Honduras. Mérito. Sentença de 29 de julho de 1988. Serie C No. 4, parágrafo 169.

${ }^{51}$ GOMES, Luiz Flávio e MAZZUOLI, Valerio de Oliveira. Comentários à Convenção Americana sobre Direitos Humanos: Pacto de San José da Costa Rica. 4.ed. rev., atual.e ampl. São Paulo: Editora Revista dos Tribunais, 2013, p. 27.

${ }^{52}$ NASH ROJAS, Claudio: El Sistema Interamericano de Derechos Humanos en acción. Aciertos y desafios. México: Porrúa, 2009, pp. 31.

${ }^{53}$ CORTE IDH. Caso Velásquez Rodríguez Vs. Honduras. Mérito. Sentença de 29 de julho de 1988. Serie C No. 4, parágrafo 166.

${ }^{54}$ CORTE IDH. Caso Velásquez Rodríguez Vs. Honduras. Mérito. Sentença de 29 de julho de 1988. Serie C No. 4, parágrafo 166.
} 
direito violado e, se for o caso, a reparação dos danos produzidos pela violação dos direitos humanos ${ }^{55}$.

Um ponto fundamental acerca da obrigação de garantir é que ela

167. [...] não se esgota com a existência de uma ordem normativa dirigida a fazer possível o cumprimento desta obrigação, mas comporta a necessidade de uma conduta governamental que assegure a existência, na realidade, de uma eficaz garantia do livre e pleno exercício dos direitos humanos ${ }^{56}$.

Percebe-se que diferentemente do dever de respeitar, a obrigação de garantir o livre e pleno exercício dos direitos é uma obrigação positiva, ou seja, seu cumprimento se traduz em um fazer ${ }^{57}$. Sendo assim, esta obrigação positiva implica na adoção, por parte dos Estados, de uma série de condutas para assegurar a efetividade dos direitos consagrados na Convenção Americana, os quais dependem do direito substantivo específico que se tenha que garantir e a situação particular do caso ${ }^{58}$.

Estas condutas que os Estados têm que adotar - o que vai depender do caso concreto e do direito violado - estão relacionadas diretamente com as implicações do dever de garantir, são obrigações de garantia específicas. Em outras palavras, os Estados têm o dever de investigar seriamente, com os meios a seu alcance, as violações que tenham sido cometidas dentro do âmbito de sua jurisdição com o objetivo de identificar os responsáveis, impor as sanções pertinentes e assegurar à vítima uma adequada reparação. Uma outra obrigação de garantia específica que decorre do artigo 1.1 da Convenção Americana é exatamente "o dever jurídico de prevenir, razoavelmente, as violações dos direitos humanos"59.

\footnotetext{
${ }^{55}$ CORTE IDH. Caso Velásquez Rodríguez Vs. Honduras. Mérito. Sentença de 29 de julho de 1988. Serie C No. 4, parágrafo 166.

${ }^{56}$ CORTE IDH. Caso Velásquez Rodríguez Vs. Honduras. Mérito. Sentença de 29 de julho de 1988. Serie C No. 4, parágrafo 167.

${ }^{57}$ GOMES, Luiz Flávio e MAZZUOLI, Valerio de Oliveira. Comentários à Convenção Americana sobre Direitos Humanos: Pacto de San José da Costa Rica. 4.ed. rev., atual.e ampl. São Paulo: Editora Revista dos Tribunais, 2013, p. 27.

${ }^{58}$ Caso González Medina y familiares Vs. República Dominicana. Excepciones Preliminares, Fondo, Reparaciones y Costas, parágrafo, 127.

${ }^{59}$ CORTE IDH. Caso Velásquez Rodríguez Vs. Honduras. Mérito. Sentença de 29 de julho de 1988. Serie C No. 4, parágrafo 174.
} 
Estas obrigações específicas são importantes porque a responsabilidade internacional de um Estado não se esgota apenas quando os agentes estatais praticam atos comissivos ou omissivos. A responsabilidade estatal também pode decorrer por atos de particulares sempre que o Estado faltar com a devida diligência para prevenir a violação ou para tratá-la nos termos requeridos pela Convenção Americana ${ }^{60}$. Em suma, nas palavras da própria Corte Interamericana,

173. O decisivo é elucidar se uma determinada violação aos direitos humanos reconhecidos pela Convenção teve lugar com o apoio ou a tolerância do poder público ou se este atuou de maneira que a transgressão tenha se realizado na ausência de toda prevenção ou impunemente. Definitivamente, trata-se de determinar se a violação aos direitos humanos resulta da inobservância por parte de um Estado de seus deveres de respeitar e de garantir ditos direitos, que lhe impõe o artigo 1.1 da Convenção ${ }^{61}$. (Grifos nosso)

Podemos já concluir então que o dever de prevenir decorre da obrigação de garantia que os Estados-partes da $\mathrm{CADH}$ assumem perante todos os indivíduos que se encontrem sob a sua jurisdição. Necessário agora, apresentar o conceito do dever de prevenir.

\section{2 - O conceito do dever de prevenção.}

O referido dever foi conceituado no julgamento, mais uma vez, do caso Velásquez Rodríguez vs. Honduras pela Corte Interamericana da seguinte forma:

"175. O dever de prevenção abarca todas as medidas de caráter jurídico, político, administrativo e cultural que promovam a salvaguarda dos direitos humanos e que assegurem que as eventuais violações aos mesmos sejam efetivamente consideradas e tratadas como um fato ilícito que, como tal, é suscetível de acarretar sanções para quem as cometa, assim como a obrigação de indenizar as vítimas por suas consequências prejudiciais. [...]. É claro, por sua vez, que a obrigação de prevenir é de meio ou comportamento, e não se

\footnotetext{
${ }^{60}$ CORTE IDH. Caso Velásquez Rodríguez Vs. Honduras. Mérito. Sentença de 29 de julho de 1988. Serie C No. 4, parágrafo 172.

${ }^{61}$ CORTE IDH. Caso Velásquez Rodríguez Vs. Honduras. Mérito. Sentença de 29 de julho de 1988. Serie C No. 4, parágrafo 173.
} 
demonstra seu descumprimento pelo simples fato de que um direito tenha sido violado. $" 62$ (Grifos nosso).

Com base no exposto, podemos extrair alguns elementos que fazem parte do chamado dever de prevenção $O$ primeiro deles é que é a prevenção pode ser concretizada pela adoção de uma medida (i) jurídica, (ii) política, (iii) administrativa ou (iv) cultural, mas o próprio Tribunal já considera que não é possível fazer uma enumeração exaustiva dessas medidas porque estas vão depender do direito material em questão e das próprias condições dos Estados-Partes ${ }^{63}$.

Outro elemento essencial deste conceito é que a obrigação de prevenir é obrigação de meio ou comportamento e não de resultado, isto é, será necessário verificar as circunstâncias fáticas de cada caso para saber se houve ou não o descumprimento por parte do Estado demandado ${ }^{64}$. Isto se justifica porque a simples violação de um direito não enseja o descumprimento do dever de prevenir.

Diante de todo o exposto, podemos concluir o seguinte (i) o artigo 1.1 da $\mathrm{CADH}$ é fundamental para configurar ou não a responsabilidade internacional de um Estado-parte; (ii) do artigo 1.1 da CADH decorrem duas obrigações genéricas assumidas pelos Estados-partes, obrigação de respeitar (não fazer) e a obrigação de garantir (fazer); (iii) da obrigação genérica de garantir surgem outras específicas que são de prevenir, investigar, sancionar e reparar os danos causados e que (iv) a responsabilidade de um Estado-parte pode ser tanto por atos de agentes estatais quanto por particulares.

Atendidos os objetivos deste capítulo, no próximo vamos analisar os julgados da Corte IDH acerca do dever de prevenção.

\footnotetext{
${ }^{62}$ CORTE IDH. Caso Velásquez Rodríguez Vs. Honduras. Mérito. Sentença de 29 de julho de 1988. Serie C No. 4, parágrafo 175.

${ }^{63}$ CORTE IDH. Caso Velásquez Rodríguez Vs. Honduras. Mérito. Sentença de 29 de julho de 1988. Serie C No. 4, parágrafo 175.

${ }^{64}$ CORTE IDH. Caso Velásquez Rodríguez Vs. Honduras. Mérito. Sentença de 29 de julho de 1988. Serie C No. 4, parágrafo 175.
} 


\section{CAPÍTULO III: O DEVER DE PREVENÇÃO ATRAVÉS DOS JULGADOS DA CORTE IDH.}

Este capítulo será destinado a análise dos dez casos selecionados os quais tratam sobre o dever de prevenção. A ordem dos julgados está agrupada nos seguintes temas: o conflito armado colombiano.

\section{1 - Caso Masacre de Pueblo Bello vs. Colômbia: Sentença de 31 de janeiro de $2006^{65}$.}

A importância deste caso está no fato de que foi a primeira vez que a Corte Interamericana começou a desenvolver o dever de prevenção de maneira mais aprofundada, estabelecendo os parâmetros do mesmo os quais vão ser reiterados em outros julgados.

\section{1 - Contexto histórico e os fatos do caso.}

O conflito armado interno colombiano e os grupos ilegais denominados "paramilitares".

A partir da década de 60 do século XX, surgiram na Colômbia diversos grupos guerrilheiros cujas atividades fizeram com que o Estado declarasse a turbação da ordem pública e estado de sítio em todo o território nacional ${ }^{66}$.

No marco da luta contra os guerrilheiros, o Estado colombiano impulsionou a criação de "grupos de autodefesas" entre a população civil, outorgando permissão para o porte e posse de armas. Estes grupos teriam a finalidade de auxiliar a força pública colombiana na defesa contra os

\footnotetext{
${ }^{65}$ CORTE IDH. Caso de la Masacre de Pueblo Bello Vs. Colômbia. Sentença de 31 de janeiro de 2006. Serie $\quad$ C $\quad$ No. $140 . \quad$ Disponível em http://www.corteidh.or.cr/docs/casos/articulos/seriec_159_esp.pdf ${ }^{66}$ CORTE IDH. Caso de la Masacre de Pueblo Bello Vs. Colômbia. Sentença de 31 de janeiro de 2006. Serie C No. 140, parágrafo 95.1.
} 
guerrilheiros ${ }^{67}$. A formação destes grupos de autodefesa foi resultado do Decreto Legislativo no 3398 de 1965, que regulava a organização da defesa nacional, porque deu fundamentação legal, através dos artigos $25^{68}$ e 33, $\S 3^{\circ 69}$, para a criação dos mesmos ${ }^{70}$.

Entretanto, na década de 80 , principalmente a partir de 1985 , ficou notório que muitos destes grupos de autodefesa mudaram seus objetivos e se converteram em grupos de delinquência, comumente chamados de "paramilitares" "11. Estes grupos se desenvolveram, primeiramente na região de Magdalena Medio e depois foram se estendendo a outras regiões do país ${ }^{72}$.

O contexto histórico de Pueblo Bello e o momento do massacre.

O distrito de Pueblo Bello era um conjunto de casas onde a população local dedicava a maior parte à agricultura. Puebelo Bello fica localizada ao sudoeste da cidade de San Pedro de Urabá e nordeste da cidade de Turbo.

Nos anos 50 foi construída uma rodovia, ligando Medellín com o golfo de Urabá. A referida rodovia proporcionou a valorização das terras da região e a convergência de forças econômicas - madeira, gado e bananeira - que determinaram a estrutura econômica de Urabá e também a sua situação política e social. Os negociantes de terras e gado adquiriram propriedades e deslocaram os camponeses da região, resultando em um crescimento da pecuária $^{73}$.

\footnotetext{
${ }^{67}$ CORTE IDH. Caso de la Masacre de Pueblo Bello Vs. Colômbia. Sentença de 31 de janeiro de 2006. Serie C No. 140, parágrafo 95.2.

${ }^{68}$ Artículo 25. Todos los colombianos, hombres y mujeres no comprendidos en el llamamiento al servicio militar obligatorio, podrán ser utilizados por el Gobierno en actividades y trabajos con los cuales contribuyan al restablecimiento de la normalidad.

${ }^{69}$ Paragrafo $3^{\circ}$. El Ministerio de Defensa Nacional, por conducto de los Comandos autorizados podrá amparar, cuando lo estime conveniente, como de propiedad particular, armas que estén consideradas como de uso privativo de las Fuerzas Armadas.

${ }^{70}$ CORTE IDH. Caso de la Masacre de Pueblo Bello Vs. Colômbia. Sentença de 31 de janeiro de 2006. Serie C No. 140, parágrafo 95.1.

${ }^{71}$ CORTE IDH. Caso de la Masacre de Pueblo Bello Vs. Colômbia. Sentença de 31 de janeiro de 2006. Serie C No. 140, parágrafo 95.3 .

${ }^{72}$ CORTE IDH. Caso de la Masacre de Pueblo Bello Vs. Colômbia. Sentença de 31 de janeiro de 2006. Serie C No. 140, parágrafo 95.4 .

${ }^{73}$ CORTE IDH. Caso de la Masacre de Pueblo Bello Vs. Colômbia. Sentença de 31 de janeiro de 2006. Serie C No. 140, parágrafo 95.22.
} 
Frente a este desenvolvimento, surgiram, nos anos 70, algumas correntes políticas campesinas que pretendiam levar a cabo uma reforma agraria, reclamavam uma melhora dos serviços públicos por parte do Estado colombiano e que recorriam a invasão de grandes latifúndios. Por outra parte, as demandas populares foram respaldadas pelas Forças Armadas Revolucionárias da Colômbia ("FARC") e pelo Exército de Libertação Popular (“ELP”), para quem a região de Urubá era de grande importância estratégica $^{74}$.

Como reação desta insurgência guerrilheira, o fenômeno dos grupos paramilitares se estendeu à região de Urubá. Fidel Castaño Gil, líder de grupos paramilitares na região, era um importante agricultor e pecuarista no município de Valencia, onde tinha várias fazendas, entre elas estava a "Las Tangas $" 75$.

Por sua vez, em decorrência da força alcançada pelas guerrilhas e pela agitação social e política, o governo criou em 1988 a Brigada XI em Montería, a Brigada Móvil Número Uno e a Jefadura Militar de Urabá ${ }^{76}$. As instalações militares ao redor de Pueblo Bello consistiram em um posto de controle na estrada de Pueblo Bello para San Pedro de Urabá e uma base militar de San Pedro de Urabá ${ }^{77}$.

Os fatos de janeiro de 1990.

Entre 13 e 14 de janeiro de 1900, um grupo de aproximadamente 60 homens fortemente armados, pertencentes a uma organização paramilitar criada por Fidel Castaño Gil denominada "los tangueros”, saíram da fazenda "Santa Mónica”, que era sua propriedade, localizada no Município de Valencia, em Córdoba. O objetivo do grupo era realizar um ataque ao distrito

\footnotetext{
${ }^{74}$ CORTE IDH. Caso de la Masacre de Pueblo Bello Vs. Colômbia. Sentença de 31 de janeiro de 2006. Serie C No. 140, parágrafo 95.24.

${ }^{75}$ CORTE IDH. Caso de la Masacre de Pueblo Bello Vs. Colômbia. Sentença de 31 de janeiro de 2006. Serie C No. 140, parágrafo 95.25 .

${ }^{76}$ CORTE IDH. Caso de la Masacre de Pueblo Bello Vs. Colômbia. Sentença de 31 de janeiro de 2006. Serie C No. 140, parágrafo 95.26.

${ }^{77}$ CORTE IDH. Caso de la Masacre de Pueblo Bello Vs. Colômbia. Sentença de 31 de janeiro de 2006. Serie C No. 140, parágrafo 95.28.
} 
de Pueblo Bello, para sequestrar um grupo de indivíduos que supostamente eram colaboradores da guerrilha ${ }^{78}$.

A motivação pessoal de Fidel Castaño, para realizar o mencionado ataque, era que no final de dezembro de 1989 a guerrilha havia roubado várias cabeças de gado de sua propriedade e que haviam feito o transporte através de Pueblo Bello até outra localidade. Em razão deste fato, Fidel Castaño considerou que os habitantes de Pueblo Bello foram os autores ou cumplices do referido episódio. Além disto, em uma data não especificada, o mordomo de Fidel Castaño tinha sido assassinado na praça de Pueblo Bello ${ }^{79}$.

No dia 14 de janeiro de 1990, entre as 20:30 e às 22:50, o grupo paramilitar de Fidel Castaño adentrou violentamente no distrito de Pueblo Bello, em dois caminhões, divididos em quatro grupos. Em cada grupo estava no comando um "chefe da comissão" e tinha funções específicas para ocupar o centro da cidade e "capturar" os "suspeitos"; cobrir rotas de fuga nas proximidades Pueblo Bello; e bloquear as vias de Pueblo Bello que conduziam a Turbo e a San Pedro de Urabá. Os paramilitares estavam carregando armas de fogo de diferentes calibres, vestiam roupas de civis, assim como uniformes de uso privativo das Forças Armadas e levavam no pescoço panos vermelhos e $\operatorname{rosados}^{80}$.

Os paramilitares saquearam algumas casas, maltrataram os ocupantes e retiraram de suas casas inúmeros homens, os quais foram levados para praça de Pueblo Bello. Além disto, alguns membros do grupo armado ingressaram na igreja localizada em frente à praça, onde ordenaram que as mulheres e as crianças permanecessem no interior da igreja e que os homens saíssem e se dirigissem à praça. Na praça, 43 homens foram escolhidos com base em uma lista que os paramilitares consultavam. Os selecionados foram

\footnotetext{
${ }^{78}$ CORTE IDH. Caso de la Masacre de Pueblo Bello Vs. Colômbia. Sentença de 31 de janeiro de 2006. Serie C No. 140 , parágrafo 95.30.

${ }^{79}$ CORTE IDH. Caso de la Masacre de Pueblo Bello Vs. Colômbia. Sentença de 31 de janeiro de 2006. Serie C No. 140, parágrafo 95.31.

${ }^{80}$ CORTE IDH. Caso de la Masacre de Pueblo Bello Vs. Colômbia. Sentença de 31 de janeiro de 2006. Serie C No. 140, parágrafo 95.32.
} 
amarrados, amordaçados e obrigados a entrar em dois caminhões utilizados como transporte ${ }^{81}$.

Os dois caminhões foram até a fazenda de "Santa Mónica", pelo caminho que comunica Pueblo Bello com San Pedro de Urabá, em uma zona declarada de emergência e operações militares ${ }^{82}$. Aproximadamente às 01:30 da madrugada do dia 15 de janeiro de 1990, os homens sequestrados foram recebidos por Fidel Castaño que ordenou que os conduzissem até uma praia, localizada na fazenda "Las Tangas" $"$. Neste local, eles foram interrogados e torturados. Como resultado, 20 homens perderam a vida e os sobreviventes foram transportados para um bosque para evitar que fossem vistos. Por volta das 07:00 da manhã, Fidel Castaño deu prosseguimento, pessoalmente, aos interrogatórios dos sobreviventes que foram torturados até a morte ${ }^{84}$.

Cerca de 22 cadáveres foram transportados para outra praia na mesma fazenda "Las Tangas", onde foram enterrados. Entretanto, até a data da sentença da Corte, não se conhecia o paradeiro de 37 vítimas ${ }^{85}$. Na manhã dia 15 de janeiro de 1990, vários familiares das vítimas sequestradas foram até a base militar de San Pedro de Urabá com objetivo de obter informações sobre o paradeiro dos desaparecidos, mas eles receberam pouca ajuda das autoridades na busca dos desaparecidos ${ }^{86}$.

Oito dias despois dos fatos ocorridos, homens vestidos de militar chegaram a Pueblo Bello em um helicóptero e, com base em uma lista, distribuíram 50.000,00 pesos colombianos entre os familiares das pessoas desaparecidas, mas muitas não receberam nada ${ }^{87}$.

\footnotetext{
${ }^{81}$ CORTE IDH. Caso de la Masacre de Pueblo Bello Vs. Colômbia. Sentença de 31 de janeiro de 2006. Serie C No. 140, parágrafo 95.33 .

${ }^{82}$ CORTE IDH. Caso de la Masacre de Pueblo Bello Vs. Colômbia. Sentença de 31 de janeiro de 2006. Serie C No. 140, parágrafo 95.36.

${ }^{83}$ CORTE IDH. Caso de la Masacre de Pueblo Bello Vs. Colômbia. Sentença de 31 de janeiro de 2006. Serie C No. 140 , parágrafo 95.38 .

${ }^{84}$ CORTE IDH. Caso de la Masacre de Pueblo Bello Vs. Colômbia. Sentença de 31 de janeiro de 2006. Serie C No. 140, parágrafo 95.40.

${ }^{85}$ CORTE IDH. Caso de la Masacre de Pueblo Bello Vs. Colômbia. Sentença de 31 de janeiro de 2006. Serie C No. 140, parágrafo 95.41.

${ }^{86}$ CORTE IDH. Caso de la Masacre de Pueblo Bello Vs. Colômbia. Sentença de 31 de janeiro de 2006. Serie C No. 140, parágrafo 95.42.

${ }^{87}$ CORTE IDH. Caso de la Masacre de Pueblo Bello Vs. Colômbia. Sentença de 31 de janeiro de 2006. Serie C No. 140, parágrafo 95.44.
} 
Estes foram o contexto e os fatos do caso, passamos agora análise das alegações das partes.

\section{2 - Alegações das partes.}

Em relação à responsabilidade do Estado, a Comissão IDH manifestou que (i) o Estado colombiano teve um papel importante no desenvolvimento dos grupos paramilitares ou de autodefesa, permitindo que estes pudessem atuar com a proteção legal e legitimidade nas décadas de 70 e 80 do século XX. O Estado colombiano pouco fez para desmantelar a estrutura que havia criado e fomentado, permitindo ainda relações daqueles grupos com os próprios agentes estatais ao solicitar ou permitir aos paramilitares a execução de certos atos ilícitos com a certeza de que não seriam objeto de investigação, julgamento ou sanção ${ }^{88}$.

Além disto, a Comissão sustentou (ii) que os objetivos do grupo paramilitar liderado por Fidel Castaño, conhecido como "los tangueros", estavam ligados a perseguição e eliminação de supostos colaboradores da guerrilha mediante um modus operandi que incluía a tortura, o assassinato seletivo e os massacres. Os "tangueros" contavam com o respaldo econômicos dos pecuaristas, dos comerciantes da região, de personalidades da vida política local e, incluso, da Força Pública colombiana, a partir do ano de 1987, com a presença da XI Brigada do Exército em Montería ${ }^{89}$; (iii) que no caso existiam elementos de prova que apontavam a cumplicidade de agentes estatais em relação aos fatos ocorridos, tanto por ação quanto por omissão. Assim, os atos de particulares comprometeram a responsabilidade do Estado colombiano, sendo suficiente demonstrar que ocorreu apoio ou tolerância do poder público pelas infrações dos direitos reconhecidos pela CADH. Sendo assim, seriam imputáveis à Colômbia tanto as violações resultantes de atos e omissões dos agentes estatais quanto aquelas cometidas

\footnotetext{
${ }^{88}$ CORTE IDH. Caso de la Masacre de Pueblo Bello Vs. Colômbia. Sentença de 31 de janeiro de 2006. Serie C No. 140, parágrafo 96(a).

${ }^{89}$ CORTE IDH. Caso de la Masacre de Pueblo Bello Vs. Colômbia. Sentença de 31 de janeiro de 2006. Serie C No. 140, parágrafo 96(b).
} 
por particulares envolvidos no desaparecimento, tortura e execução das vítimas ${ }^{90}$.

Diante das citadas alegações, a Comissão IDH sustentou que a Colômbia era responsável pela violação aos artigos $4^{091}, 5^{092}$ e $7^{093}$ da CADH em prejuízo das 43 vítimas do caso por ações de civis com a aquiescência e colaboração de agentes do Estado ${ }^{94}$.

Por sua vez, os representantes das vítimas complementaram (i) que à época dos fatos os desaparecimentos forçados em Urabá eram uma prática

\footnotetext{
${ }^{90}$ CORTE IDH. Caso de la Masacre de Pueblo Bello Vs. Colômbia. Sentença de 31 de janeiro de 2006. Serie C No. 140, parágrafo 96(c).

${ }^{91}$ Artigo 4. Direito à vida 1 . Toda pessoa tem o direito de que se respeite sua vida. Esse direito deve ser protegido pela lei e, em geral, desde o momento da concepção. Ninguém pode ser privado da vida arbitrariamente. 2. Nos países que não houverem abolido a pena de morte, esta só poderá ser imposta pelos delitos mais graves, em cumprimento de sentença final de tribunal competente e em conformidade com lei que estabeleça tal pena, promulgada antes de haver o delito sido cometido. Tampouco se estenderá sua aplicação a delitos aos quais não se aplique atualmente. 3. Não se pode restabelecer a pena de morte nos Estados que a hajam abolido. 4. Em nenhum caso pode a pena de morte ser aplicada por delitos políticos, nem por delitos comuns conexos com delitos políticos. 5 . Não se deve impor a pena de morte a pessoa que, no momento da perpetração do delito, for menor de dezoito anos, ou maior de setenta, nem aplicá-la a mulher em estado de gravidez. 6 . Toda pessoa condenada à morte tem direito a solicitar anistia, indulto ou comutação da pena, os quais podem ser concedidos em todos os casos. Não se pode executar a pena de morte enquanto o pedido estiver pendente de decisão ante a autoridade competente.

${ }_{92}$ Artigo 5. Direito à integridade pessoal 1 . Toda pessoa tem o direito de que se respeite sua integridade física, psíquica e moral. 2. Ninguém deve ser submetido a torturas, nem a penas ou tratos cruéis, desumanos ou degradantes. Toda pessoa privada da liberdade deve ser tratada com o respeito devido à dignidade inerente ao ser humano. 3. A pena não pode passar da pessoa do delinqüente. 4 . Os processados devem ficar separados dos condenados, salvo em circunstâncias excepcionais, e ser submetidos a tratamento adequado à sua condição de pessoas não condenadas. 5. Os menores, quando puderem ser processados, devem ser separados dos adultos e conduzidos a tribunal especializado, com a maior rapidez possível, para seu tratamento. 6. As penas privativas da liberdade devem ter por finalidade essencial a reforma e a readaptação social dos condenados.

${ }^{93}$ Artigo 7.Direito à liberdade pessoal 1 . Toda pessoa tem direito à liberdade e à segurança pessoais. 2. Ninguém pode ser privado de sua liberdade física, salvo pelas causas e nas condições previamente fixadas pelas constituições políticas dos Estados Partes ou pelas leis de acordo com elas promulgadas. 3. Ninguém pode ser submetido a detenção ou encarceramento arbitrários. 4. Toda pessoa detida ou retida deve ser informada das razões da sua detenção e notificada, sem demora, da acusação ou acusações formuladas contra ela. 5. Toda pessoa detida ou retida deve ser conduzida, sem demora, à presença de um juiz ou outra autoridade autorizada pela lei a exercer funções judiciais e tem direito a ser julgada dentro de um prazo razoável ou a ser posta em liberdade, sem prejuízo de que prossiga o processo. Sua liberdade pode ser condicionada a garantias que assegurem o seu comparecimento em juízo. 6. Toda pessoa privada da liberdade tem direito a recorrer a um juiz ou tribunal competente, a fim de que este decida, sem demora, sobre a legalidade de sua prisão ou detenção e ordene sua soltura se a prisão ou a detenção forem ilegais. Nos Estados Partes cujas leis prevêem que toda pessoa que se vir ameaçada de ser privada de sua liberdade tem direito a recorrer a um juiz ou tribunal competente a fim de que este decida sobre a legalidade de tal ameaça, tal recurso não pode ser restringido nem abolido. $\mathrm{O}$ recurso pode ser interposto pela própria pessoa ou por outra pessoa. 7. Ninguém deve ser detido por dívidas. Este princípio não limita os mandados de autoridade judiciária competente expedidos em virtude de inadimplemento de obrigação alimentar. ${ }^{94}$ CORTE IDH. Caso de la Masacre de Pueblo Bello Vs. Colômbia. Sentença de 31 de janeiro de 2006. Serie C No. 140, parágrafo $97($ a).
} 
sistemática e que tinha por objetivo gerar terror na população civil para que não colaborassem ou apoiassem as guerrilhas. Sendo que tal prática era na maioria das vezes realizadas por grupos paramilitares com o apoio ou tolerância das forças militares e, às vezes, até com a participação direta destes ${ }^{95}$; (ii) que os fatos do caso se realizaram em um contexto de alta militarização na zona de Urabá como parte de um plano militar de extermínio e aniquilamento das guerrilhas que atuavam nesta zona e que (iii) apesar do excepcional controle militar na região, os grupos paramilitares tiveram toda a liberdade e cooperação das autoridades militares para executar os fatos de Peublo Bello 96

Em sua defesa, o Estado da Colômbia (i) negou em especial que tenha sido responsável de maneira geral pela existência e fortalecimento dos grupos paramilitares $^{97}$; (ii) que não seria possível atribuir a responsabilidade ao Estado pela expedição de normas que deram fundamentos legais a criação de grupos armados de autodefesa ilegais ${ }^{98}$; (iii) que não lhe era imputável a responsabilidade por este caso concreto, nem por infração as suas obrigações convencionais, seja por tolerância ou apoio do poder público pelos fatos de Pueblo Bello ${ }^{99}$.

Em relação ao conteúdo dos artigos $4^{\circ}, 5^{\circ}$ e $7^{\circ}$ da CADH, a Colômbia alegou que (iv) não poderia existir a responsabilidade internacional objetiva imputada ao Estado apenas pelo fato de que um grupo armado ilegal violou os direitos humanos de maneira flagrante. Para o Estado colombiano, ao ser imputado a violação ao dever de proteção, não implicaria automaticamente a infração ao dever de garantia, porque, em cada caso, seria necessário determinar a qualidade da infração; (v) para poder se atribuído

\footnotetext{
${ }^{95}$ CORTE IDH. Caso de la Masacre de Pueblo Bello Vs. Colômbia. Sentença de 31 de janeiro de 2006. Serie C No. 140, parágrafo 99(a).

${ }^{96}$ CORTE IDH. Caso de la Masacre de Pueblo Bello Vs. Colômbia. Sentença de 31 de janeiro de 2006. Serie C No. 140, parágrafo 100 (a).

${ }^{97}$ CORTE IDH. Caso de la Masacre de Pueblo Bello Vs. Colômbia. Sentença de 31 de janeiro de 2006. Serie C No. 140, parágrafo 102(a).

${ }^{98}$ CORTE IDH. Caso de la Masacre de Pueblo Bello Vs. Colômbia. Sentença de 31 de janeiro de 2006. Serie C No. 140, parágrafo 102(b).

${ }^{99}$ CORTE IDH. Caso de la Masacre de Pueblo Bello Vs. Colômbia. Sentença de 31 de janeiro de 2006. Serie C No. 140, parágrafo 102(d).
} 
responsabilidade ao Estado por atos cometidos diretamente por particulares, seria imperioso levar em conta as estruturas da imputação de um fato ao Estado, as quais derivam das obrigações consagradas na Convenção Americana. Somente quando se demonstre que o comportamento dos integrantes do grupo armado ilegal é imputável por ação ou omissão aos membros das Forças Armadas colombianas, porque descumpriram com os deveres convencionais frente aos fatos dos particulares, poderá ser atribuída ao Estado a responsabilidade internacional. Em contrário, se se estabelece que os fatos não são imputáveis aos militares, não existe base jurídica para atribuir ao Estado a violação aos direitos humanos em concreto.

Quanto especificamente do dever de prevenção, o governo colombiano argumentou que (vi) o cumprimento das obrigações a cargo do Estado exige estabelecer prioridades, levando em conta as restrições de recursos e as disponibilidades efetivas de um Estado, as quais podem resultar em limites válidos ao gozo de um direito quando respondem aos critérios da razoabilidade e proporcionalidade. Neste sentido, tal parâmetro tem maior relevância quando se trata do dever de prevenção a cargo do Estado, porque a responsabilidade é de meio e não de resultado, o que supõe um dever de diligencia no sentido de tomar razoavelmente as previsões e cautelas para evitar a violação de um direito por parte de terceiros ${ }^{100}$; (vii) que resultava impossível atribuir a ao Estado a infração ao dever genérico de prevenção e a lesão a este dever no caso concreto porque a atividade militar na zona demonstrava a diligencia estatal na prevenção de qualquer atentado contra os direitos humanos dos habitantes da região. Não apenas se tratava da presença militar permanente e proporcional, mas também de operativos constantes de perseguição aos membros de grupos armados presentes na região de Urubá e que os militares presentes na região não tinham conhecimento algum dos fatos, nem lhes foram conhecíveis ${ }^{101}$ e que (viii) existiam elementos no

${ }^{100}$ CORTE IDH. Caso de la Masacre de Pueblo Bello Vs. Colômbia. Sentença de 31 de janeiro de 2006. Serie C No. 140, parágrafo 103(i).

${ }^{101}$ CORTE IDH. Caso de la Masacre de Pueblo Bello Vs. Colômbia. Sentença de 31 de janeiro de 2006. Serie C No. 140, parágrafo 103(j). 
processo que apontavam o total desconhecimento por parte dos militares acerca da situação concreta de perigo e de uma possibilidade de ataque à população ${ }^{102}$.

Tendo sido expostos os posicionamentos de cada lado, passamos agora ao da Corte IDH. Inicialmente, o Tribunal estabeleceu o marco de responsabilidade dos Estados frente à $\mathrm{CADH}$. Tal responsabilidade está relacionada com as duas obrigações genéricas previstas no artigo $1.1 \mathrm{da}$ CADH, a obrigação de respeitar e garantir, que são de caráter erga omnes. Determinou ainda que destas obrigações decorrem outras especiais, e uma delas é exatamente a que trata do dever de prevenção ${ }^{103}$.

Em um segundo momento, a Corte passou a estabelecer a importância de o Estado-parte proteger o direito à vida frente a sua obrigação de garantir. O Estado tem que proteger o direito à vida em todos os níveis de sua atuação e também de prevenir e proteger os indivíduos de atos criminais de outros indivíduos. Em outras palavras, o Tribunal reitera a questão da responsabilidade do estatal resultante das relações entre particulares. Nesta questão, a Corte IDH diz que a responsabilidade estatal por atos de particulares não é ilimitada porque está condicionada a certos requisitos para consubstanciar o dever do Estado de adotar as medidas necessárias para prevenir e proteger os particulares nas relações entre $\mathrm{si}^{104}$.

Neste momento, a Corte IDH começou a estabelecer os requisitos que configuram o dever de prevenção. Tais requisitos são: a) conhecimento de uma situação real de risco ou imediato para um indivíduo ou um grupo de indivíduos determinados, b) possibilidades razoáveis de prevenir ou evitar esse risco ${ }^{105}$. Estes foram os dois requisitos que a Corte estabeleceu para averiguar se no caso concreto o Estado colombiano havia falhado em adotar

${ }^{102}$ CORTE IDH. Caso de la Masacre de Pueblo Bello Vs. Colômbia. Sentença de 31 de janeiro de 2006. Serie C No. 140, parágrafo 103(n).

${ }^{103}$ CORTE IDH. Caso de la Masacre de Pueblo Bello Vs. Colômbia. Sentença de 31 de janeiro de 2006. Serie C No. 140, parágrafo 111.

${ }^{104}$ CORTE IDH. Caso de la Masacre de Pueblo Bello Vs. Colômbia. Sentença de 31 de janeiro de 2006. Serie C No. 140, parágrafo 120.

${ }^{105}$ CORTE IDH. Caso de la Masacre de Pueblo Bello Vs. Colômbia. Sentença de 31 de janeiro de 2006. Serie C No. 140, parágrafo 123. 
as medidas de proteção e prevenção frente a atos cometidos por um grupo de paramilitares, ou seja, frente a atos praticados por particulares.

Ao analisar quais foram as atitudes tomadas pelo governo colombiano, o Tribunal reconheceu que o Estado adotou várias medidas legislativas para proibir, prevenir e punir as atividades dos grupos de autodefesa ou paramilitares e diante da situação de risco em Pueblo Bello. A Corte IDH reconheceu que a Colômbia adotou medidas que materializaram a necessidade de controlar a zona. Em virtude das medidas tomadas, a Corte IDH considerou que o Estado tinha o conhecimento da situação de risco que vivia a população civil da região, este risco decorrente das atividades de grupo de pessoas ou de paramilitares no local. Logo, o primeiro requisito que caracteriza o dever de prevenir estava preenchido.

Quanto ao segundo requisito - possibilidades razoáveis de prevenir ou evitar esse risco - o Tribunal considerou que as medidas adotadas não foram suficientes para a desativação concreta e do risco efetivo que o próprio Estado ajudou a criar. A Corte IDH sustentou que a criação de grupos de autodefesas ou paramilitares gerou uma situação concreta de risco na região e que o governo não foi capaz de adotar medias capazes de acabar com o risco. Neste sentido, um ponto importante para o desenvolvimento do dever de prevenção, a Corte IDH disse que em situações destas de riscos - violência sistemáticas e graves violações de direitos humanos, em uma zona declarada de emergência e operações militares ${ }^{106}$ - acentua os deveres especiais de prevenção e proteção a cargo do Estado nas zonas em que existam a presença de grupos paramilitares ${ }^{107}$.

Em sua conclusão, o Tribunal afirmou o seguinte

"140. La Corte observa que si bien la masacre de Pueblo Bello ocurrida en enero de 1990 fue organizada y perpetrada por miembros de grupos paramilitares, aquélla no habría podido ejecutarse si hubiere existido protección efectiva de la población civil en una situación de riesgo razonablemente previsible por parte

${ }^{106}$ CORTE IDH. Caso de la Masacre de Pueblo Bello Vs. Colômbia. Sentença de 31 de janeiro de 2006. Serie C No. 140, parágrafo 134.

${ }^{107}$ CORTE IDH. Caso de la Masacre de Pueblo Bello Vs. Colômbia. Sentença de 31 de janeiro de 2006. Serie C No. 140, parágrafo 126. 
de miembros de las Fuerzas Armadas o de seguridad del Estado. Ciertamente no existen pruebas ante este Tribunal que demuestren que el Estado dirigiera directamente la ejecución de la masacre o que existiese un nexo entre miembros del Ejército y los grupos paramilitares o una delegación de funciones públicas de aquél a éstos. No obstante, la responsabilidad por los actos de los miembros del grupo paramilitar en este caso en particular es atribuible al Estado en la medida en que éste no adoptó diligentemente las medidas necesarias para proteger a la población civil en función de las circunstancias descritas. Por las razones expuestas en los párrafos anteriores, la Corte concluye que el Estado no cumplió con su obligación de garantizar los derechos humanos consagrados en los artículos 4, 5 y 7 de la Convención, por haber faltado a sus deberes de prevención y protección, en perjuicio de las personas desaparecidas y privadas de su vida en este caso. " 108 (Grifos nosso)

A partir deste caso no qual a Corte IDH enfrentou pela primeira vez o dever de prevenção, podemos tirar algumas conclusões: (i) trata-se de uma obrigação de meio; (ii) os requisitos que configuram o dever de prevenção foram resultantes de uma situação de violação de direitos humanos cometida por particulares; (iii) o risco real ou imediato deve ser frente a uma pessoa ou grupo determinado e não apenas determinável e que (iv) a Corte IDH não especificou o que seriam possibilidades razoáveis de prevenir ou evitar esse risco.

Na sequência, iremos verificar o segundo julgado em que o Tribunal enfrentou o dever de prevenção. Ele foi selecionado porque foram reiterados os requisitos acerca do dever de prevenção, mas sob a perspectiva dos direitos dos membros de uma comunidade indígena, e porque trata-se de um contexto totalmente diferente deste primeiro caso.

\section{2 - Caso Comunidad Indígena Sawhoyamaxa Vs. Paraguai: Sentença de 29 de março de $2006^{109}$.}

2.1 - Inicialmente: esclarecimentos quanto o número de vítimas.

\footnotetext{
${ }^{108}$ CORTE IDH. Caso de la Masacre de Pueblo Bello Vs. Colômbia. Sentença de 31 de janeiro de 2006. Serie C No. 140, parágrafo 140.

${ }^{109}$ CORTE IDH. Caso Comunidad Indígena Sawhoyamaxa Vs. Paraguay. Fondo, Reparaciones y Costas. Sentencia de 29 de marzo de 2006. Serie C No. 146. Disponível em http://www.corteidh.or.cr/docs/casos/articulos/seriec 146 esp2.pdf
} 
Antes de considerar o contexto histórico e os fatos do caso, a Corte IDH estabeleceu um capítulo prévio na sentença cujo objetivo era determinar o objeto da alegada violação ao artigo $4^{\circ}$ da CADH. O Tribunal então analisou diversas listas, que foram apresentadas pela Comissão e pelos representantes das vítimas durante o tramite do caso, de membros da comunidade indígena que teriam falecidos em consequência de omissões do Estado paraguaio frente ao seu dever de prevenir o direito à vida ${ }^{110}$.

Após verificar as listas de cada parte, a Corte IDH concluiu que iria analisar a possível violação ao artigo $4^{\circ}$ da CADH em relação a 30 membros da comunidade que haviam falecido ${ }^{111}$.

\section{2 - Contexto histórico e os fatos do caso.}

No final do século XIX, grandes extensões de terra do Chaco paraguaio foram adquiridas por empresários britânicos, em decorrência da dívida do Paraguai após a guerra da Tripla Aliança. A divisão e venda destes territórios foi realizada com o desconhecimento da população indígena que habitava até então a região ${ }^{112}$.

Desde então, as terras do Chaco paraguaio foram transferidas para a propriedade privada e fracionadas progressivamente. Com isto, aumentaram as restrições da população indígena ao acesso as suas terras tradicionais, produzindo mudanças significativas na práticas de subsistência da população indígena. Para a alimentação, os indígenas dependiam cada vez mais do trabalho assalariado e aproveitavam a permanência temporal nas distintas fazendas da zona para seguirem praticando com as suas atividades de subsistência (caça, pesca e agricultura) ${ }^{113}$.

\footnotetext{
${ }^{110}$ CORTE IDH. Caso Comunidad Indigena Sawhoyamaxa Vs. Paraguay. Fondo, Reparaciones y Costas. Sentencia de 29 de marzo de 2006. Serie C No. 146, parágrafo 61.

${ }^{111}$ CORTE IDH. Caso Comunidad Indigena Sawhoyamaxa Vs. Paraguay. Fondo, Reparaciones y Costas. Sentencia de 29 de marzo de 2006. Serie C No. 146, parágrafo 72.

${ }^{112}$ CORTE IDH. Caso Comunidad Indigena Sawhoyamaxa Vs. Paraguay. Fondo, Reparaciones y Costas. Sentencia de 29 de marzo de 2006. Serie C No. 146, parágrafo 73.1.

${ }^{113}$ CORTE IDH. Caso Comunidad Indígena Sawhoyamaxa Vs. Paraguay. Fondo, Reparaciones y Costas. Sentencia de 29 de marzo de 2006. Serie C No. 146, parágrafo 73.4.
} 
A comunidade Sawhoyamaxa é formada por indígenas que já habitavam tradicionalmente as terras do Chaco paraguaio e os membros comunidade pertenciam a povos que ocuparam ancestralmente a região do Chaco $^{114}$.

Em 1991, a comunidade indígena deu início ao processo de reivindicação terras, que foram ocupadas tradicionalmente e formavam parte do seu habitat natural ${ }^{115}$. Neste momento, a comunidade agrupava os habitantes de várias aldeias indígenas que estavam dispersas em diferentes fazendas de $\operatorname{gado}^{116}$.

No dia 21 de abril de 1997, os líderes da comunidade apresentaram um informe antropológico para as autoridades administrativa no qual se detalhava, entre outras coisas, que estavam ocorrendo mortes nas aldeias da comunidade, que por anos os seus membros não estavam recebendo atenção médica e, por consequência disto tudo, era constante o falecimento de crianças por enfermidades facilmente curáveis ${ }^{117}$.

As condições de vida dos membros da comunidade Sawhoymaxa e o dano real.

Dentro das fazendas de gado, os membros da comunidade indígena viviam em situação de pobreza extrema, caracterizada por baixos níveis de saúde e atenção médica, exploração trabalhista e restrições de possuir cultivos e gados próprios, de praticar livremente as atividades tradicionais de subsistência ${ }^{118}$.

A maioria dos membros da comunidade então decidiu sair destas fazendas e passaram a viver a margem de uma rodovia nacional em condições

\footnotetext{
${ }^{114}$ CORTE IDH. Caso Comunidad Indígena Sawhoyamaxa Vs. Paraguay. Fondo, Reparaciones y Costas. Sentencia de 29 de marzo de 2006. Serie C No. 146, parágrafo 73.5.

115 CORTE IDH. Caso Comunidad Indígena Sawhoyamaxa Vs. Paraguay. Fondo, Reparaciones y Costas. Sentencia de 29 de marzo de 2006. Serie C No. 146, parágrafo 73.9.

${ }^{116}$ CORTE IDH. Caso Comunidad Indigena Sawhoyamaxa Vs. Paraguay. Fondo, Reparaciones y Costas. Sentencia de 29 de marzo de 2006. Serie C No. 146, parágrafo 73.6.

${ }^{117}$ CORTE IDH. Caso Comunidad Indígena Sawhoyamaxa Vs. Paraguay. Fondo, Reparaciones y Costas. Sentencia de 29 de marzo de 2006. Serie C No. 146, parágrafo 159.

118 CORTE IDH. Caso Comunidad Indígena Sawhoyamaxa Vs. Paraguay. Fondo, Reparaciones y Costas. Sentencia de 29 de marzo de 2006. Serie C No. 146, parágrafo 73.61.
} 
de pobreza extrema, sem nenhum tipo de serviços, a espera de que os organismos competentes resolvessem a sua solicitude de reivindicação de terras. Esta situação foi reconhecida em 23 de junho de 1999 pelo então Presidente do país, mediante o Decreto $n^{\circ} 3789$ que declarou estado de emergência $^{119}$ da comunidade indígena Sawhoyamaxa ${ }^{120}$.

Este decreto presidencial reconhecia que a comunidade estava privada do acesso aos meios de subsistência tradicional ligados à sua identidade cultural, em virtude da proibição dos proprietários de terra ao ingresso dos indígenas na região, dificultando o desenvolvimento de vida da comunidade frente a falta de meios de alimentação e assistência médica mínima e indispensável. O decreto reconhecia ainda a preocupação do governo paraguaio em exigir uma resposta urgente e determinava a execução de ações que correspondessem a imediata atenção médica e alimentícia às famílias da comunidade indígena, enquanto durasse o processo de reivindicação das terras $^{121}$.

Apesar da declaração de emergência da comunidade Sawhoyamaxa, os seus membros seguiam vivendo em condições precárias sem contar com os serviços básicos mínimos ${ }^{122}$. Eles não contavam com um posto ou centro de saúde em seus assentamentos e eram visitados em poucas ocasiões por agentes de saúde ${ }^{123}$.

Dentro deste contexto de precárias condições de vida e saúde narradas e do paralelo tramite judicial de reivindicação de terras, o dano real sofrido aos membros da comunidade indígena, em especial de crianças e idosos, foi a vulnerabilidade a enfermidade e epidemias e, em particular, as mortes

\footnotetext{
${ }^{119}$ Este decreto também tinha declarado situação de emergência em relação à comunidade indígena Yakye Axa.

${ }^{120}$ CORTE IDH. Caso Comunidad Indigena Sawhoyamaxa Vs. Paraguay. Fondo, Reparaciones y Costas. Sentencia de 29 de marzo de 2006. Serie C No. 146, parágrafo 73.62.

${ }^{121}$ CORTE IDH. Caso Comunidad Indigena Sawhoyamaxa Vs. Paraguay. Fondo, Reparaciones y Costas. Sentencia de 29 de marzo de 2006. Serie C No. 146, parágrafo 73.63.

122 CORTE IDH. Caso Comunidad Indígena Sawhoyamaxa Vs. Paraguay. Fondo, Reparaciones y Costas. Sentencia de 29 de marzo de 2006. Serie C No. 146, parágrafo 73.67.

${ }^{123}$ CORTE IDH. Caso Comunidad Indígena Sawhoyamaxa Vs. Paraguay. Fondo, Reparaciones y Costas. Sentencia de 29 de marzo de 2006. Serie C No. 146, parágrafo 73.72.
} 
ocorridas $^{124}$ por causa de tétano, pneumonia, sarampo, graves quadros de desidratação, caquexia e enterocolite ou até mesmo por acidentes de trânsito e trabalho. Tudo isto sem nenhum controle estatal ${ }^{125}$.

\section{3 - Alegações das partes.}

Em sua manifestação, a Comissão IDH alegou o Paraguai violou o artigo $4^{\circ}$ da $\mathrm{CADH}$ porque (i) tinha descumprido com a sua obrigação de garantir o direito à vida dos membros da comunidade indígena ao não ter reconhecido e tutelado as terras ancestrais da comunidade indígena, obrigando estes a viverem à margem de uma rodovia e privados de acederem aos meios tradicionais de subsistência; (ii) a distribuição de alimentos e assistência médica por parte do Estado aos membros da comunidade tinha sido deficitária e irregular e que (iii) as causas das mortes das vítimas foram por doenças que eram fáceis de se prevenir e curar, e até mesmo evita-las, permitindo aos membros da comunidade que vivessem em um meio ambiente saudável ${ }^{126}$.

Ao complementar as alegações da Comissão, os representantes das vítimas alegaram que (i) o Estado do Paraguai não tinha adotado as medidas necessárias para superar as condições de extrema vulnerabilidade e risco em que viviam os membros da comunidade indígena; (ii) não tinha adotado as medidas necessárias para prevenir e evitar a morte dos membros da comunidade indígena e que (iii) quando o Estado declarou situação de emergência na comunidade indígena e se comprometeu a adotar as medidas necessárias para garantir o direito à vida, à integridade física e a segurança dos membros da comunidade, os serviços disponibilizados foram

\footnotetext{
${ }^{124}$ Todas as informações (tais como o dia do óbito, a causa da morte, se tinha recebido ou não atenção médica e se tinha deixado algum familiar) das 30 vítimas que faleceram estão descritas no parágrafo 73.74 da sentença.

${ }^{125}$ CORTE IDH. Caso Comunidad Indigena Sawhoyamaxa Vs. Paraguay. Fondo, Reparaciones y Costas. Sentencia de 29 de marzo de 2006. Serie C No. 146, parágrafo 73.74.

${ }^{126}$ CORTE IDH. Caso Comunidad Indígena Sawhoyamaxa Vs. Paraguay. Fondo, Reparaciones y Costas. Sentencia de 29 de marzo de 2006. Serie C No. 146, parágrafo 145.
} 
insuficientes e deficitários, permanecendo a situação de risco e vulnerabilidade $^{127}$.

O Estado do Paraguai, por sua vez, alegou que não houve violação ao artigo $4^{\circ}$ da $\mathrm{CADH}$ porque (i) tinha colocado à disposição dos povos indígenas um serviço público de saúde; (ii) os líderes da comunidade indígena, talvez mal assessorados, tinham conduzidos os membros de sua comunidade a situações extremas, distantes de suas formas tradicionais de subsistência, ao instalá-los à margem de uma rodovia como forma de protesto alheio aos seus costumes; (iii) que dentro de suas limitações próprias de um país de menor desenvolvimento e afetado pelo comércio internacional e de suas possibilidade financeiras, tinha criado condições necessárias para garantir a existência digna das populações indígenas, oferecendo assistência alimentícia e sanitária de forma periódica e que (iv) não se podia ser atribuída responsabilidade ao Estado por mortes naturais ou fortuitas, salvo no caso de provar a negligencia dos agentes sanitários ou outras autoridades que tinham conhecimento dos fatos ${ }^{128}$.

Em sua análise, a Corte IDH, inicialmente, teceu comentários sobre a importância do direito à vida. Segundo o Tribunal, o direito à vida em um direito humano fundamental cujo gozo pleno é um pré-requisito para o disfruto de todos os demais direitos humanos ${ }^{129}$.

Em virtude deste papel fundamental, os Estados têm a obrigação de garantir a criação das condições necessárias para que não ocorram violações a este direito inalienável ${ }^{130}$. Em razão disto, os Estados devem adotar as medidas necessárias para criar um marco normativo adequado que desencoraje qualquer ameaça ao direito à vida, que estabeleça um sistema de justiça efetivo capaz de investigar, punir e reparar toda privação da vida por

\footnotetext{
${ }^{127}$ CORTE IDH. Caso Comunidad Indigena Sawhoyamaxa Vs. Paraguay. Fondo, Reparaciones y Costas. Sentencia de 29 de marzo de 2006. Serie C No. 146, parágrafo 146.

${ }^{128}$ CORTE IDH. Caso Comunidad Indigena Sawhoyamaxa Vs. Paraguay. Fondo, Reparaciones y Costas. Sentencia de 29 de marzo de 2006. Serie C No. 146, parágrafo 147.

${ }^{129}$ CORTE IDH. Caso Comunidad Indígena Sawhoyamaxa Vs. Paraguay. Fondo, Reparaciones y Costas. Sentencia de 29 de marzo de 2006. Serie C No. 146, parágrafo 150.

${ }^{130}$ CORTE IDH. Caso Comunidad Indígena Sawhoyamaxa Vs. Paraguay. Fondo, Reparaciones y Costas. Sentencia de 29 de marzo de 2006. Serie C No. 146, parágrafo 151.
} 
parte de agentes estatais ou por particulares e que proteja o direito à que não se impeça o acesso às condições que garantem uma vida digna, o que inclui a adoção de medidas positivas para prevenir a violação do direito à vida ${ }^{131}$.

A Corte continuando a sua análise ressaltou que

155. Es claro [...] que un Estado no puede ser responsable por cualquier situación de riesgo al derecho a la vida. Teniendo en cuenta las dificultades que implica la planificación y adopción de políticas públicas y las elecciones de carácter operativo que deben ser tomadas en función de prioridades y recursos, las obligaciones positivas del Estado deben interpretarse de forma que no se imponga a las autoridades una carga imposible o desproporcionada. ${ }^{132}$ (Grifos nosso)

Para que surja esta obrigação positiva, segundo a Corte IDH, fazendo referência ao caso Masacre De Pueblo Bello vs. Colômbia,

155. [...] debe establecerse que al momento de los hechos las autoridades sabían o debían saber de la existencia de una situación de riesgo real e inmediato para la vida de un individuo o grupo de individuos determinados, y no tomaron las medidas necesarias dentro del ámbito de sus atribuciones que, juzgadas razonablemente, podían esperarse para prevenir o evitar ese riesgo ${ }^{133}$

Estabelecidas tais premissas, a Corte Interamericana verificou a aplicação dos requisitos transcritos no caso. Antes, destacou que a controvérsia do julgamento residia em determinar se o Estado era o responsável pelas mortes das vítimas nas situações em que estas se encontravam e se ele tinha adotado as medidas necessárias, dentro do âmbito de suas atribuições que, julgadas razoavelmente, podiam se esperar para prevenir ou evitar o risco ao direito à vida das vítimas ${ }^{134}$.

Quanto ao conhecimento prévio de uma situação de risco real ou imediato, a Corte IDH entendeu que a partir do dia 21 de abril de 1997,

\footnotetext{
${ }^{131}$ CORTE IDH. Caso Comunidad Indigena Sawhoyamaxa Vs. Paraguay. Fondo, Reparaciones y Costas. Sentencia de 29 de marzo de 2006. Serie C No. 146, parágrafo 153.

${ }^{132}$ CORTE IDH. Caso Comunidad Indígena Sawhoyamaxa Vs. Paraguay. Fondo, Reparaciones y Costas. Sentencia de 29 de marzo de 2006. Serie C No. 146, parágrafo 155.

${ }^{133}$ CORTE IDH. Caso Comunidad Indigena Sawhoyamaxa Vs. Paraguay. Fondo, Reparaciones y Costas. Sentencia de 29 de marzo de 2006. Serie C No. 146, parágrafo 155.

${ }^{134}$ CORTE IDH. Caso Comunidad Indígena Sawhoyamaxa Vs. Paraguay. Fondo, Reparaciones y Costas. Sentencia de 29 de marzo de 2006. Serie C No. 146, parágrafo 156.
} 
quando foi entregue o informe antropológico, o Estado tinha pleno conhecimento da situação de risco real e a vulnerabilidade em que permaneciam os membros da comunidade, em especial as crianças, mulheres grávidas e idosos ${ }^{135}$.

Quanto ao segundo requisito, adotar medidas razoáveis, a Corte IDH observou novamente a data de 21 de abril de 1997 para analisar se o Paraguai tinha adotado as medidas necessárias dentro do âmbito de suas atribuições ${ }^{136}$. O Tribunal entendeu que o Estado não tomou medidas necessárias que fizessem os membros da comunidade indígena sair das margens da rodovia, onde eles estavam vivendo, para outro lugar mais seguro e onde lhes fossem garantidos serviços mínimos. O Estado permitiu uma situação de perigo ao direito à vida ${ }^{137}$.

Além disto, a Corte IDH considerou que o Estado não tomou nenhuma medida concreta para prevenir a vulneração do direito à vida das vítimas do caso. O Tribunal destacou que a maioria das mortes foram de crianças com três anos de idades, todas por doenças razoavelmente previsíveis, evitáveis e de baixo custo para tratá-las ${ }^{138}$. Terminando sua análise quanto ao dever de prevenção, a Corte Interamericana decidiu que

\begin{abstract}
“178. [...] el Estado violó el artículo 4.1 de la Convención Americana, en relación con el artículo 1.1 de la misma, por cuanto no ha adoptado las medidas positivas necesarias dentro del ámbito de sus atribuciones, que razonablemente eran de esperarse para prevenir o evitar el riesgo al derecho a la vida de los miembros de la Comunidad Sawhoyamaxa. La Corte considera que las muertes de 18 niños miembros de la Comunidad [...] son atribuibles al Estado, precisamente por la falta de prevención, lo que constituye además una violación del artículo 19 de la Convención. Asimismo, la Corte declara que el Estado violó el artículo 4.1 de la Convención Americana, en relación con el artículo 1.1 de la misma, por la muerte del señor Luis Torres Chávez, quien falleció por enterocolitis, sin ningún tipo de atención médica"139. (Grifos nosso)
\end{abstract}

\footnotetext{
135 CORTE IDH. Caso Comunidad Indigena Sawhoyamaxa Vs. Paraguay. Fondo, Reparaciones y Costas. Sentencia de 29 de marzo de 2006. Serie C No. 146, parágrafo 159.

${ }^{136}$ CORTE IDH. Caso Comunidad Indígena Sawhoyamaxa Vs. Paraguay. Fondo, Reparaciones y Costas. Sentencia de 29 de marzo de 2006. Serie C No. 146, parágrafo 160.

${ }^{137}$ CORTE IDH. Caso Comunidad Indigena Sawhoyamaxa Vs. Paraguay. Fondo, Reparaciones y Costas. Sentencia de 29 de marzo de 2006. Serie C No. 146, parágrafo 165.

${ }^{138}$ CORTE IDH. Caso Comunidad Indígena Sawhoyamaxa Vs. Paraguay. Fondo, Reparaciones y Costas. Sentencia de 29 de marzo de 2006. Serie C No. 146, parágrafo 171.

${ }^{139}$ CORTE IDH. Caso Comunidad Indígena Sawhoyamaxa Vs. Paraguay. Fondo, Reparaciones y Costas. Sentencia de 29 de marzo de 2006. Serie C No. 146, parágrafo 178.
} 
Deste julgado podemos concluir que (i) a Corte IDH considerou que no caso existia uma situação de risco real devido as condições em que viviam os membros da comunidade e pelas mortes na região em virtude da omissão do Estado em prestar serviços de saúde; que (ii) o dever de prevenção foi considerado violado não por atos praticados por particulares, mas sim pelo próprio governo que não tinha adotado medidas necessárias e que (iii) o dever de prevenção foi analisado com a perspectiva de que o Estado tinha uma obrigação positiva em prevenir a violação do direito à vida dos membros da comunidade indígena.

O próximo caso que vamos analisar é importante porque foi a primeira vez que o Tribunal teve a oportunidade de se pronunciar acerca da violação dos direitos de uma pessoa sofria com uma incapacidade mental ${ }^{140}$. A escolha se deu com o objetivo de verificar quais são as particularidades do Estado frente ao dever de prevenção em relação às pessoas com deficiência e por não envolver um grupo determinado como foi dois casos anteriores.

\section{3 - Caso Ximenes Lopes Vs. Brasil: Sentença de 4 de julho de $2006^{141}$.}

\section{1 - Contexto histórico e os fatos do caso.}

O senhor Damião Ximenes Lopes nasceu no dia 25 de junho de $1969^{142}$. Na juventude, ele desenvolveu uma deficiência metal de origem orgânica proveniente de alterações no funcionamento do seu cérebro ${ }^{143}$. $\mathrm{Na}$ primeira vez que foi internado em 1995 na Casa de Repouso Guararapes, que era um centro privado que operava dentro do Sistema Único de Saúde ("SUS"), por um período de 2 meses, a vítima ao regressar a sua casa, encontrava-se em melhor estado, mas apresentava feridas nos joelhos e nos

\footnotetext{
${ }^{140}$ CORTE IDH. Caso Ximenes Lopes Vs. Brasil. Sentencia de 4 de julio de 2006. Serie C No. 149, parágrafo 123.

${ }^{141}$ CORTE IDH. Caso Ximenes Lopes Vs. Brasil. Sentencia de 4 de julio de 2006. Serie C No. 149. Disponível em http://www.corteidh.or.cr/sitios/libros/todos/docs/por2.pdf

${ }^{142}$ CORTE IDH. Caso Ximenes Lopes Vs. Brasil. Sentencia de 4 de julio de 2006. Serie C No. 149, parágrafo 112.1 .

${ }^{143}$ CORTE IDH. Caso Ximenes Lopes Vs. Brasil. Sentencia de 4 de julio de 2006. Serie C No. 149, parágrafo 112.2.
} 
tornozelos, que justificou declarando que havia sido vítima de violência na referida casa $^{144}$.

Passando alguns anos, em uma sexta-feira de $1^{\circ}$ de outubro de 1999 , o senhor Damião Ximenes foi internado por sua mãe, a senhora Albertina Viana Lopes, mais uma vez na Casa de Repouso Guararapes, para receber um tratamento psiquiátrico ${ }^{145}$. Neste mesmo dia, ele foi admitido na instituição, como paciente SUS, em perfeito estado físico. No momento de sua entrada, não apresentava sinais de agressividade nem lesões corporais externas $^{146}$.

No dia 3 de outubro de 1999, o senhor Damião Ximenes teve uma crise de agressividade e estava desorientado. A vítima entrou em um banheiro na Casa de Repouso Guararapes e se negava a sair, motivo pelo qual foi dominado e retirado à força por um auxiliar de enfermagem e por outros dois pacientes da instituição. Em seguida, a vítima foi submetida a contenção física e médico da clínica determinou que fossem aplicados certos medicamentos ${ }^{147}$. Na noite deste mesmo dia, a vítima teve um novo episódio de agressividade e voltou a ser submetida a contenção física, a que esteve submetido entre a noite de domingo e a manhã da segunda-feira ${ }^{148}$.

No dia 4 de outubro, aproximadamente às 09h, a mãe de senhor Damião Ximenes chegou à Casa de Repouso Guararapes para visitá-lo e o encontrou sangrando, com hematomas, com a roupa rasgada, sujo e cheirando a excremento, com as mãos amarradas para trás, com dificuldades para respirar, agonizante e gritando e pedindo socorro à polícia. Continuava

\footnotetext{
${ }^{144}$ CORTE IDH. Caso Ximenes Lopes Vs. Brasil. Sentencia de 4 de julio de 2006. Serie C No. 149, parágrafo 112.3 .

${ }^{145}$ CORTE IDH. Caso Ximenes Lopes Vs. Brasil. Sentencia de 4 de julio de 2006. Serie C No. 149, parágrafo 112.4 .

${ }^{146}$ CORTE IDH. Caso Ximenes Lopes Vs. Brasil. Sentencia de 4 de julio de 2006. Serie C No. 149, parágrafo 112.5 .

${ }^{147}$ CORTE IDH. Caso Ximenes Lopes Vs. Brasil. Sentencia de 4 de julio de 2006. Serie C No. 149, parágrafo 112.7 .

${ }^{148}$ CORTE IDH. Caso Ximenes Lopes Vs. Brasil. Sentencia de 4 de julio de 2006. Serie C No. 149, parágrafo 112.8 .
} 
submetido à contenção física que lhe havia sido aplicada desde a noite anterior, já apresentava escoriações ${ }^{149}$.

A mãe da vítima, então, solicitou aos funcionários da Casa de Repouso Guararapes que banhassem seu filho e procurou um médico que o atendesse. Encontrou Francisco Ivo de Vasconcelos, que era diretor clínico e médico da clínica, que, sem realizar exames físicos em Damião Ximenes Lopes, receitou-lhe alguns remédios e em seguida se retirou do hospital. Nenhum médico ficou a cargo da instituição nesse momento ${ }^{150}$.

No dia 4 de outubro de 1999, às 11h30, na Casa de Repouso Guararapes, a vítima veio a falecer em circunstâncias violentas, aproximadamente duas horas depois de haver sido medicado, sem ser assistido por médico algum no momento de sua morte, já que a unidade pública de saúde em que se encontrava internado para receber cuidados psiquiátricos não dispunha de nenhum médico naquele momento. Não se prestou ao senhor Damião Ximenes Lopes a assistência adequada e o paciente encontrava-se, em virtude da falta de cuidados, à mercê de todo tipo de agressão e acidentes que poderiam colocar em risco sua vida ${ }^{151}$.

Posteriormente à morte da vítima, o médico Francisco Ivo de Vasconcelos foi chamado e regressou à Casa de Repouso Guararapes. Examinou o corpo e declarou sua morte, fazendo constar que o cadáver não apresentava lesões externas e que a causa da morte havia sido uma parada cardiorrespiratória. O médico não ordenou a realização de necropsia no corpo do senhor Damião Ximenes Lopes. A mãe se inteirou da morte de seu filho ao chegar a sua casa ${ }^{152}$.

\footnotetext{
${ }^{149}$ CORTE IDH. Caso Ximenes Lopes Vs. Brasil. Sentencia de 4 de julio de 2006. Serie C No. 149, parágrafo 112.9 .

${ }^{150}$ CORTE IDH. Caso Ximenes Lopes Vs. Brasil. Sentencia de 4 de julio de 2006. Serie C No. 149, parágrafo 112.10 .

${ }^{151}$ CORTE IDH. Caso Ximenes Lopes Vs. Brasil. Sentencia de 4 de julio de 2006. Serie C No. 149, parágrafo 112.11 .

${ }^{152}$ CORTE IDH. Caso Ximenes Lopes Vs. Brasil. Sentencia de 4 de julio de 2006. Serie C No. 149, parágrafo 112.12 .
} 


\section{As condições na Casa de Repouso Guararapes $^{153}$.}

$\mathrm{Na}$ Casa de Repouso Guararapes existia um contexto de violência contra as pessoas ali internadas, que estavam sob a ameaça constante de serem agredidas diretamente pelos funcionários do hospital ou de que estes não impedissem as agressões entre os pacientes, uma vez que era frequente que os funcionários não fossem capacitados para trabalhar com pessoas portadoras de deficiência mental.

Os doentes se encontravam sujeitos a violência também quando seu estado de saúde se tornava crítico, já que a contenção física e o controle de pacientes que entravam em crise eram muitas vezes realizados com a ajuda de outros pacientes. A violência, no entanto, não era o único obstáculo para a recuperação dos pacientes da Casa de Repouso Guararapes, mas também as precárias condições de manutenção, conservação e higiene, bem como da assistência médica, igualmente constituíam uma afronta à dignidade das pessoas ali internadas.

$\mathrm{O}$ armazenamento dos alimentos era inadequado; as condições higiênicas e sanitárias eram precárias, os banheiros se achavam danificados, sem chuveiro, lavatório ou cesta de lixo, e o serviço sanitário se encontrava sem cobertura nem higiene; não havia médico de plantão, o atendimento médico aos pacientes era frequentemente prestado na recepção do hospital e algumas vezes não havia medicação; faltavam aparelhos essenciais na sala de emergência, tais como tubos de oxigênio, "aspirador de secreção" e vaporizador; os prontuários médicos não registravam a evolução dos pacientes nem os relatórios circunstanciados de acompanhamento que deviam apresentar os profissionais de assistência social, psicologia, terapia ocupacional e enfermagem; o proprietário do hospital não se encontrava presente de maneira assídua, motivo por que era evidente a falta de administração.

\footnotetext{
${ }^{153}$ CORTE IDH. Caso Ximenes Lopes Vs. Brasil. Sentencia de 4 de julio de 2006. Serie C No. 149, parágrafo 120 .
} 


\section{2 - Alegações das partes.}

A Comissão IDH sustentou que o Estado brasileiro tinha violado o direito à vida da vítima porque (i) o Brasil não tinha exercido devidamente a fiscalização na Casa de Repouso Guararapes; em relação à violação da integridade pessoal da vítima, a Comissão alegou que (ii) as condições de hospitalização na Casa de Repouso Guararapes eram incompatíveis com o respeito à dignidade da pessoa humana e que (iii) a vítima não foi mantida em condições dignas, nem sob cuidado, a uma supervisão imediata e regular de pessoal qualificado acerca da saúde mental ${ }^{154}$.

Os representantes das vítimas, quanto à violação do artigo $4^{\circ}$ da $\mathrm{CADH}$, alegaram que (i) o Estado brasileiro falhou na sua obrigação de preservar e proteger a vida do Sr. Ximenes Lopes tendo em vista que não tinha adotado medidas de prevenção para impedir a sua morte, não físcalizou, nem monitorou o funcionamento da Casa de Repouso Guararapes; quanto à violação do artigo $5^{\circ}$, os representantes sustentaram que (ii) o Sr. Ximenes Lopes foi submetido a trato cruéis, desumanos e degradantes na instituição. As agressões foram perpetradas por indivíduos que tinham a guarda da vítima e que tinham o dever de cuidar dele, resguardar a saúde e integridade pessoal do paciente. As condições de internação e os cuidados oferecidos eram atentatórios ao direito à integridade pessoal.

Por fim, os representantes das vítimas consideraram especificamente que (iii) o Brasil tinha violado quatro deveres que tinha em relação aos pacientes da Casa de Repouso Guararapes, a) prevenir os danos não naturais, b) investigar e permanecer informado sobre as condições do hospital, c) monitorar e controlar os funcionário e d) não causar, de forma negligente ou intencional, a morte de pacientes que se encontrem sob a sua custódia ${ }^{155}$.

\footnotetext{
${ }^{154}$ CORTE IDH. Caso Ximenes Lopes Vs. Brasil. Sentencia de 4 de julio de 2006. Serie C No. 149, parágrafo 113.

${ }^{155}$ CORTE IDH. Caso Ximenes Lopes Vs. Brasil. Sentencia de 4 de julio de 2006. Serie C No. 149, parágrafo 114 .
} 
Por sua vez, o Estado brasileiro não contestou porque reconheceu a sua responsabilidade internacional pela violação dos artigos 4.1 e 5.1 da CADH em detrimento do senhor Damião Ximenes ${ }^{156}$.

Considerações prévias quanto a responsabilidade estatal na área de saúde.

Em sua análise do caso, a Corte IDH pautou inicialmente que a responsabilidade internacional de um Estado pode decorrer não apenas de condutas cometidas por agentes estatais, mas também por atitudes de particulares. Neste caso, a responsabilidade estatal decorre pela sua omissão em evitar que terceiros violem os bens jurídicos que protegem os direitos humanos.

Ocorre que entre a responsabilidade por agentes estatais, de um lado e, de outro, a responsabilidade por agentes particulares, existe também a conduta de uma pessoa ou entidade que, embora não seja um órgão estatal, está autorizada pela legislação do Estado em exercer atribuições de autoridade governamental. Nesta última hipótese, a conduta, seja de pessoa física ou jurídica, deve ser considerada como um ato do Estado, desde que praticada em tal capacidade ${ }^{157}$.

Feitas estas importantes observações prévias, a Corte IDH concluiu que

100. Neste caso, a Casa de Repouso Guararapes, onde faleceu Damião Ximenes Lopes, era um hospital privado de saúde contratado pelo Estado para prestar serviços de atendimento psiquiátrico sob a direção do Sistema Único de Saúde e atuava como unidade pública de saúde em nome e por conta do Estado [...]. O Estado, por conseguinte, é responsável pela conduta do pessoal da Casa de Repouso Guararapes, que exercia elementos de autoridade estatal ao prestar o serviço público de saúde sob a direção do Sistema Único de Saúde. ${ }^{158}$ (grifos nosso)

\footnotetext{
${ }^{156}$ CORTE IDH. Caso Ximenes Lopes Vs. Brasil. Sentencia de 4 de julio de 2006. Serie C No. 149, parágrafo 115 .

${ }^{157}$ CORTE IDH. Caso Ximenes Lopes Vs. Brasil. Sentencia de 4 de julio de 2006. Serie C No. 149, parágrafo 86.

${ }^{158}$ CORTE IDH. Caso Ximenes Lopes Vs. Brasil. Sentencia de 4 de julio de 2006. Serie C No. 149, parágrafo 100 .
} 
Os deveres do Estado com relação às pessoas que sofrem de deficiência mental.

Superada as questões prévias, a Corte IDH assentou que da obrigação geral de garantia dos direitos à vida e à integridade física surgem deveres especiais de proteção e prevenção, os quais, no caso, se traduziam em deveres de cuidar e de regular ${ }^{159}$.

Quanto ao dever de cuidar, a Corte destacou primeiro que os Estados estão em uma posição especial de garante em relação às pessoas com deficiência mental, os países têm a obrigação positiva de proporcionar as condições necessárias para desenvolver uma vida digna para estas pessoas ${ }^{160}$.

Em segundo lugar, quando as pessoas estão recebendo um atendimento médico, os Estados têm que adotar as medidas disponíveis e necessárias para impedir a deterioração das condições do paciente e otimizar a sua saúde ${ }^{161}$. Em síntese, o dever de cuidado se reveste em maior atenção quando as pessoas que estejam recebendo um tratamento médico são deficientes mentais, ainda mais quando se encontram em instituições psiquiátricas $^{162}$.

Quanto ao dever de regular,

141. O Tribunal dispôs que o dever dos Estados de regular e fiscalizar as instituições que prestam serviço de saúde, como medida necessária para a devida proteção da vida e integridade das pessoas sob sua jurisdição, abrange tanto as entidades públicas e privadas que prestam serviços públicos de saúde quanto aquelas instituições que prestam exclusivamente serviços privados de saúde [...]. Especialmente com relação às instituições que prestam serviço público de saúde, como fazia a Casa de Repouso Guararapes, o Estado não somente deve regular-las e fiscalizá-las, mas tem, ademais, o especial dever de cuidado com relação às pessoas ali internadas. ${ }^{163}$

\footnotetext{
${ }^{159}$ CORTE IDH. Caso Ximenes Lopes Vs. Brasil. Sentencia de 4 de julio de 2006. Serie C No. 149, parágrafo 137.

${ }^{160}$ CORTE IDH. Caso Ximenes Lopes Vs. Brasil. Sentencia de 4 de julio de 2006. Serie C No. 149, parágrafo 138.

${ }^{161}$ CORTE IDH. Caso Ximenes Lopes Vs. Brasil. Sentencia de 4 de julio de 2006. Serie C No. 149, parágrafo 139.

${ }^{162}$ CORTE IDH. Caso Ximenes Lopes Vs. Brasil. Sentencia de 4 de julio de 2006. Serie C No. 149, parágrafo 140 .

${ }^{163}$ CORTE IDH. Caso Ximenes Lopes Vs. Brasil. Sentencia de 4 de julio de 2006. Serie C No. 149, parágrafo 141 .
} 
Quanto aos fatos do caso, a Corte IDH observou que o Brasil tinha a obrigação regulamentar e fiscalizar a Casa de Repouso Guararapes porque esta funcionava no âmbito do sistema público de saúde do Estado brasileiro $^{164}$. Além disto considerou que o governo brasileiro conhecia as condições de internação que a instituição oferecia na época dos fatos ${ }^{165}$.

Em seu prosseguimento, o Tribunal destacou que

146. O Estado tem responsabilidade internacional por descumprir, neste caso, seu dever de cuidar e de prevenir a vulneração (sic) da vida e da integridade pessoal, bem como seu dever de regulamentar e fiscalizar o atendimento médico de saúde, os quais constituem deveres especiais decorrentes da obrigação de garantir os direitos consagrados nos artigos 4 e 5 da Convenção Americana. ${ }^{166}$ (grifos nosso)

Em suas conclusões, a Corte Interamericana disse que

150. [...] por haver faltado com seus deveres de respeito, prevenção e proteção, com relação à morte e os tratos cruéis, desumanos e degradantes sofridos pelo senhor Damião Ximenes Lopes, o Estado tem responsabilidade pela violação dos direitos à vida e à integridade pessoal consagrados nos artigos 4.1 e 5.1 e 5.2 da Convenção Americana, em relação com o artigo 1.1 desse mesmo tratado, em detrimento do senhor Damião Ximenes Lopes. ${ }^{167}$

Concluímos a partir deste caso envolvendo o Estado brasileiro que (i) a responsabilidade estatal pode decorrer pelo fato de uma pessoa física ou jurídica estar exercendo atividades delegadas pelo Estado - de modo específico tratava-se da área da saúde - , como era o caso da clínica psiquiátrica Casa de Repouso Guararapes e, por esta condição, (ii) o dever de prevenção se traduz em um dever de regular/fiscalizar e cuidar que os governos devem observar para cumprir o artigo 1.1 da $\mathrm{CADH}$ quanto à obrigação de garantia e (iii) o Estado está em uma posição de garante frente

${ }^{164}$ CORTE IDH. Caso Ximenes Lopes Vs. Brasil. Sentencia de 4 de julio de 2006. Serie C No. 149, parágrafo 142 .

${ }^{165}$ CORTE IDH. Caso Ximenes Lopes Vs. Brasil. Sentencia de 4 de julio de 2006. Serie C No. 149, parágrafo 143.

${ }^{166}$ CORTE IDH. Caso Ximenes Lopes Vs. Brasil. Sentencia de 4 de julio de 2006. Serie C No. 149, parágrafo 146.

${ }^{167}$ CORTE IDH. Caso Ximenes Lopes Vs. Brasil. Sentencia de 4 de julio de 2006. Serie C No. 149, parágrafo 150 . 
às pessoas que sofrem algum tipo de deficiência mental, reforçando ainda mais o seu dever de prevenir as violações aos direitos consagrados na CADH.

$\mathrm{Na}$ sequência, iremos verificar um julgado em que a Corte IDH enfrentou o dever de prevenção envolvendo um defensor de direitos humanos. Nós selecionamos o caso porque existem algumas particularidades quanto ao dever dos Estados frente aos defensores de direitos humanos.

\section{4 - Caso Valle Jaramillo e Outros Vs. Colômbia: Sentença de 27 de novembro de $2008^{168}$.}

\section{1 - Contexto histórico e os fatos do caso.}

A demanda se relaciona com a morte do senhor Jesús Valle Jaramillo, que era um conhecido defensor de direitos humanos. A partir de 1996, a vítima começou a denunciar ativamente os crimes cometidos por paramilitares, assim como a colaboração e aquiescência entres estes e membros do Exército Nacional colombiano ${ }^{169}$. A maior parte de suas denúncias eram do Município de Ituango, na Colômbia.

A situação de risco particular que vivia a vítima se evidenciou, por exemplo, quando logo após haver denunciado as intimidações contra a população civil e os massacres sucedidos em meados das décadas de $90 \mathrm{em}$ aldeias e bairros do Município de Ituango, ele recebeu de um enviado do então chefe paramilitar Carlos Castaño Gil, quem o advertiu ao senhor Valle Jaramillo que deveria deixar o país ou permanecer em silêncio "para não ter que matá-1o"170. Apesar das ameaças, a vítima continuou firme em seu trabalho como defensor de direitos humanos ${ }^{171}$.

\footnotetext{
${ }^{168}$ Corte IDH. Caso Valle Jaramillo y otros Vs. Colombia. Fondo, Reparaciones y Costas. Sentencia de 27 de noviembre de 2008. Serie C No. 192. Disponível em http://www.corteidh.or.cr/docs/casos/articulos/seriec 192 esp.pdf

${ }_{169}$ CORTE IDH. Caso Valle Jaramillo y otros Vs. Colombia. Fondo, Reparaciones y Costas. Sentencia de 27 de noviembre de 2008. Serie C No. 192, parágrafo 73.

170 CORTE IDH. Caso Valle Jaramillo y otros Vs. Colombia. Fondo, Reparaciones y Costas. Sentencia de 27 de noviembre de 2008. Serie C No. 192, parágrafo 93.

${ }_{171}$ CORTE IDH. Caso Valle Jaramillo y otros Vs. Colombia. Fondo, Reparaciones y Costas. Sentencia de 27 de noviembre de 2008. Serie C No. 192, parágrafo 93.
} 
Um mês antes de sua morte, Jesús María Valle Jaramillo havia feito observações em um fórum na IV Brigada do exército acerca da convivência entre membros das forças estatais e os paramilitares, particularmente sobre o cometimento de mais de 150 assassinatos em Ituango ${ }^{172}$.

Assim mesmo, um dia antes de sua morte, a vítima declarou sobre as referidas observações no processo de injurias e calunias ajuizado contra ele por um membro de um batalhão militar ${ }^{173}$.

Em 27 de fevereiro de 1998, dois homens armados ingressaram na oficia de trabalho do Sr. Valle Jaramillo, localizada na cidade de Medellín, e mataram o defensor de direitos humanos. No mesmo local estavam o senhor. Carlos Fernando Jaramillo Correa e a irmã da vítima, a senhora. Nelly Valle Jaramillo, que foram amarrados e posteriormente ameaçados com armas de fogo. Apesar de terem sido ajuizados uma série de ações judiciais, não se realizaram maiores investigações, nem os responsáveis foram punidos pelos atos cometidos ${ }^{174}$.

O governo colombiano tinha adotado uma série de medidas com o intuito de favorecer e proteger os defensores de direitos humanos. Entre tais medidas destacam-se: o reconhecimento legal das organizações de defensores de direitos humanos; a criação e implementação do Plano Nacional de Ação em Direitos Humanos e Direito Internacional Humanitário e a proteção policial fornecidas às organizações de direitos humanos ${ }^{175}$.

Apesar disto, em nenhum momento o Estado colombiano negou que existisse um alto risco de vulnerabilidade para a vida do senhor Valle Jaramillo. Inclusive, o Estado reconheceu a sua responsabilidade pela

172 CORTE IDH. Caso Valle Jaramillo y otros Vs. Colombia. Fondo, Reparaciones y Costas. Sentencia de 27 de noviembre de 2008. Serie C No. 192, parágrafo 94.

${ }^{173}$ CORTE IDH. Caso Valle Jaramillo y otros Vs. Colombia. Fondo, Reparaciones y Costas. Sentencia de 27 de noviembre de 2008. Serie C No. 192, parágrafo 94.

174 CORTE IDH. Caso Valle Jaramillo y otros Vs. Colombia. Fondo, Reparaciones y Costas. Sentencia de 27 de noviembre de 2008. Serie C No. 192, parágrafo 2.

${ }_{175}$ CORTE IDH. Caso Valle Jaramillo y otros Vs. Colombia. Fondo, Reparaciones y Costas. Sentencia de 27 de noviembre de 2008. Serie C No. 192, parágrafo 85. 
omissão em razão de que, apesar de conhecer que este risco existia, não tomou as medidas necessárias para prevenir as suas consequências ${ }^{176}$.

\section{2 - Alegações das partes.}

A Comissão IDH e os representantes das vítimas alegaram que o Estado colombiano tinha violado os artigos $4^{\circ}, 5^{\circ}$ e $7^{\circ}$ da CADH em relação ao senhor Valle Jaramillo porque (i) a execução da vítima não era um caso isolado já que tinha ocorrido em um contexto específico como parte de uma cadeia de homicídios, perseguições, acusações e ataques contra pessoas e organizações sociais dedicados a defesa dos direitos humanos e que (ii) as autoridades conheciam o risco e até adotaram medidas para enfrentá-lo, mas não resultaram suficientes ${ }^{177}$.

Neste caso, não foram disponibilizados os argumentos do Estado da Colômbia porque este reconheceu a sua responsabilidade internacional pela violação dos artigos $4^{\circ}, 5^{\circ}$ e $7^{\circ}$ da CADH em detrimento de Valle Jaramillo por omissão ao seu dever de garantia ${ }^{178}$.

A particular situação dos defensores de direitos humanos.

Em sua análise, a Corte Interamericana inicialmente abordou a situação específica dos defensores de direitos humanos. A Corte IDH pautou que o dever dos Estados de criarem as condições necessárias para o efetivo gozo dos direitos consagrados na $\mathrm{CADH}$, está intrinsecamente ligado à proteção e ao reconhecimento da importância do papel que cumprem os defensores de direitos humanos cujos trabalhos são fundamentais para o fortalecimento da democracia e do Estado de Direito ${ }^{179}$.

\footnotetext{
176 CORTE IDH. Caso Valle Jaramillo y otros Vs. Colombia. Fondo, Reparaciones y Costas. Sentencia de 27 de noviembre de 2008. Serie C No. 192, parágrafo 92.

177 CORTE IDH. Caso Valle Jaramillo y otros Vs. Colombia. Fondo, Reparaciones y Costas. Sentencia de 27 de noviembre de 2008. Serie C No. 192, parágrafos 65 e 66.

${ }_{178}$ CORTE IDH. Caso Valle Jaramillo y otros Vs. Colombia. Fondo, Reparaciones y Costas. Sentencia de 27 de noviembre de 2008. Serie C No. 192, parágrafo 20 (a, i).

179 CORTE IDH. Caso Valle Jaramillo y otros Vs. Colombia. Fondo, Reparaciones y Costas. Sentencia de 27 de noviembre de 2008. Serie C No. 192, parágrafo 87.
} 
Neste sentido, o Tribunal ressaltou que as atividades de vigilância, denuncia e educação que realizam os defensores de direitos humanos contribuem de maneira essencial para a observância dos direitos humanos, porque eles atuam como garantes contra a impunidade ${ }^{180}$.

Nesta linha de raciocínio, a Corte IDH objetivamente disse que

90. [...] un Estado tiene la obligación de adoptar todas las medidas necesarias y razonables para garantizar el derecho a la vida, libertad personal e integridad personal de aquellos defensores $\mathbf{y}$ defensoras que denuncien violaciones de derechos humanos y que se encuentren en una situación de especial vulnerabilidad como lo es el conflicto armado interno colombiano, siempre y cuando el Estado tenga conocimiento de un riesgo real e inmediato en contra de éstos y toda vez que existan posibilidades razonables de prevenir o evitar ese riesgo. ${ }^{181}$ (Grifos nosso)

Posteriormente, ao analisar o risco real no caso, a Corte IDH reiterou o julgado do caso Massacre de Pueblo Bello no sentindo de responsabilizar o Estado da Colômbia por ter propiciado a criação dos grupos de autodefesas no país, criando assim uma situação objetiva de risco para os habitantes. $\mathrm{O}$ Tribunal considerou que o mencionado risco gerado agravou ainda mais a situação dos defensores de direitos humanos no país que, como a vítima do caso, denunciavam episódios de violações perpetrados por paramilitares e pela força pública estatal ${ }^{182}$.

A Corte IDH considerou que certos pronunciamentos feitos pela vítima dias antes de sua morte, alertando a sociedade dos vínculos entre a força de segurança pública e os paramilitares, o colocaram em grave risco para a sua vida, liberdade e integridade pessoal.

Quanto as medidas tomadas pelo Estado colombiano, Corte IDH disse que no caso concreto o governo não tomou medidas razoáveis e necessárias

\footnotetext{
${ }^{180}$ CORTE IDH. Caso Valle Jaramillo y otros Vs. Colombia. Fondo, Reparaciones y Costas. Sentencia de 27 de noviembre de 2008. Serie C No. 192, parágrafo 88.

${ }^{181}$ CORTE IDH. Caso Valle Jaramillo y otros Vs. Colombia. Fondo, Reparaciones y Costas. Sentencia de 27 de noviembre de 2008. Serie C No. 192, parágrafo 90.

${ }^{182}$ CORTE IDH. Caso Valle Jaramillo y otros Vs. Colombia. Fondo, Reparaciones y Costas. Sentencia de 27 de noviembre de 2008. Serie C No. 192, parágrafo 81.
} 
para evitar as violações aos direitos à vida, liberdade e integridade pessoal da vítima $^{183}$.

Quanto às medidas razoáveis que os Estados podem tomar diante de uma situação envolvendo defensores de direitos humanos, o Tribunal disse o sequinte

91. Para tales efectos, los Estados deben facilitar los medios necesarios para que las defensoras y los defensores que denuncian violaciones de derechos humanos realicen libremente sus actividades; protegerlos cuando son objeto de amenazas para evitar los atentados a su vida e integridad; generar las condiciones para la erradicación de violaciones por parte de agentes estatales o de particulares; abstenerse de imponer obstáculos que dificulten la realización de su labor, e investigar seria y eficazmente las violaciones cometidas en su contra, combatiendo la impunidad ${ }^{184}$.

Segundo a Corte, nos atos cometidos por particulares, a responsabilidade era atribuída ao Estado porque por omissão este descumpriu com as suas obrigações convencionais erga omnes de garantir a efetividade dos direitos humanos nas relações interindividuais. Tal omissão foi concretizada e agravada por não ter sido capaz de suprimir ou resolver efetivamente a situação de risco propiciada pela existência de grupos paramilitares $^{185}$.

Em sua conclusão,

105. [...] el Tribunal considera que el Estado no cumplió con su deber de adoptar las medidas necesarias y razonables con el fin de garantizar efectivamente el derecho a la libertad personal, integridad personal y vida del señor Jesús María Valle Jaramillo, quien se encontraba en un grave riesgo en razón de las denuncias públicas que realizaba como defensor de derechos humanos dentro del conflicto interno colombiano. La responsabilidad internacional por los hechos del presente caso es atribuible al Estado en la medida en que éste incumplió con su deber de prevención y de investigación, deberes ambos que derivan de los

${ }^{183}$ CORTE IDH. Caso Valle Jaramillo y otros Vs. Colombia. Fondo, Reparaciones y Costas. Sentencia de 27 de noviembre de 2008. Serie C No. 192, parágrafo 95.

${ }^{184}$ CORTE IDH. Caso Valle Jaramillo y otros Vs. Colombia. Fondo, Reparaciones y Costas. Sentencia de 27 de noviembre de 2008. Serie C No. 192, parágrafo 91.

${ }^{185}$ CORTE IDH. Caso Valle Jaramillo y otros Vs. Colombia. Fondo, Reparaciones y Costas. Sentencia de 27 de noviembre de 2008. Serie C No. 192, parágrafo 92. 
artículos 4, 5 y 7 de la Convención leídos conjuntamente con el artículo 1.1 de dicho instrumento, que obliga al Estado a garantizar el goce de los derechos. ${ }^{186}$

As conclusões que tiramos deste caso, frente ao dever de prevenção, é (i) a Corte IDH estabeleceu que, em situações envolvendo defensores de direitos humanos, os Estados-partes têm a obrigação de adotar todas as medidas necessárias e razoáveis para garantir o direito à vida, liberdade e integridade pessoal dos defensores que denunciem violações de direitos humano, porque estes se encontram em uma situação especial de vulnerabilidade ${ }^{187}$ e que (ii) o parâmetro de análise do dever de prevenção foi diferente dos casos anteriores, porque, além do contexto de violência colombiano, a vítima tomou atitudes que alertavam às autoridades sobre a sua situação de risco.

O quinto julgado que selecionamos é importante porque trata-se de um caso histórico para a Corte IDH, por envolver a violência contra a mulher, a Convenção Belém do Pará, e porque foram analisados dois momentos diferentes em torno do dever de prevenção.

\section{5 - Caso González e outras ("Campo Algodonero") Vs. México: Sentença de 16 de novembro de $2009^{188}$.}

\section{1 - Contexto histórico e fatos do caso.}

Os fatos do caso ocorreram na cidade mexicana de Juárez que está localizada ao norte do Estado de Chihuahua ${ }^{189}$. Nesta cidade, desde o ano de 1993 o número de homicídio de mulheres tinha aumentando bastante, havendo pelo menos 264 vítimas até o ano de 2001 e 379 até o ano de 2005.

\footnotetext{
${ }^{186}$ CORTE IDH. Caso Valle Jaramillo y otros Vs. Colombia. Fondo, Reparaciones y Costas. Sentencia de 27 de noviembre de 2008. Serie C No. 192, parágrafo 105.

187 CORTE IDH. Caso Valle Jaramillo y otros Vs. Colombia. Fondo, Reparaciones y Costas. Sentencia de 27 de noviembre de 2008. Serie C No. 192, parágrafo 90.

${ }^{188}$ CORTE IDH. Caso González y otras ("Campo Algodonero") Vs. México. Excepción Preliminar, Fondo, Reparaciones y Costas. Sentencia de 16 de noviembre de 2009. Serie C No.205. Disponível em http://www.corteidh.or.cr/sitios/libros/todos/docs/porl.pdf

${ }^{189}$ CORTE IDH. Caso González y otras (“Campo Algodonero") Vs. México. Excepción Preliminar, Fondo, Reparaciones y Costas. Sentencia de 16 de noviembre de 2009. Serie C No.205, parágrafo 113.
} 
Alguns destes crimes apresentavam um alto grau de violência contra as mulheres, incluindo a sexual, e que, em geral, tais homicídios foram influenciados por uma cultura de discriminação contra a mulher, incidindo tanto na modalidade dos crimes, bem como na resposta das autoridades estatais. Por consequência das respostas ineficientes e atitudes indiferentes documentadas em relação à investigação destes crimes, a violência contra a mulher na cidade de Juárez foi se perpetuando ${ }^{190}$.

Em decorrência deste contexto de violência, em 1998 o México criou a Promotoria Especial para a Investigação de Homicídios de Mulheres em Juárez ${ }^{191}$. Outras medidas foram tomadas, mas a Corte IDH não as levou em consideração porque não tinha material probatório suficiente ou porque foram posteriores ao ano de 2001, data da morte das vítimas ${ }^{192}$.

Quanto ao caso mais especificamente, a demanda se relacionada com a responsabilidade internacional do Estado mexicano pelo desaparecimento e posterior morte das jovens Claudia Ivette González, Esmeralda Herrera Monreal e Laura Berenice Ramos Monárrez, cujos corpos foram encontrados em uma plantação de algodão de Ciudad Juárez no dia 6 de novembro de 2001 .

Laura Berenice Ramos tinha 17 anos de idade ${ }^{193}$ e desapareceu em 22 de setembro de 2001. No dia 25 de setembro, a mãe da jovem apresentou uma denúncia perante autoridades estatais, que neste mesmo dia elaboraram o relatório de desaparecimento ${ }^{194}$.

\footnotetext{
${ }^{190}$ CORTE IDH. Caso González y otras (“Campo Algodonero”) Vs. México. Excepción Preliminar, Fondo, Reparaciones y Costas. Sentencia de 16 de noviembre de 2009. Serie C No.205, parágrafo 164.

${ }^{191}$ CORTE IDH. Caso González y otras (“Campo Algodonero") Vs. México. Excepción Preliminar, Fondo, Reparaciones y Costas. Sentencia de 16 de noviembre de 2009. Serie C No.205, parágrafo 262.

${ }^{192}$ CORTE IDH. Caso González y otras (“Campo Algodonero") Vs. México. Excepción Preliminar, Fondo, Reparaciones y Costas. Sentencia de 16 de noviembre de 2009. Serie C No.205, parágrafos $269 / 271$.

${ }^{193}$ CORTE IDH. Caso González y otras (“Campo Algodonero") Vs. México. Excepción Preliminar, Fondo, Reparaciones y Costas. Sentencia de 16 de noviembre de 2009. Serie C No.205, parágrafo 165.

${ }^{194}$ CORTE IDH. Caso González y otras (“Campo Algodonero") Vs. México. Excepción Preliminar, Fondo, Reparaciones y Costas. Sentencia de 16 de noviembre de 2009. Serie C No.205, parágrafo 171.
} 
Claudia Ivette tinha 20 anos de idade e no dia 10 de outubro de 2001, após ter chegado dois minutos atrasada no trabalho foi impedida de entrar. Neste mesmo dia, ela desapareceu ${ }^{195}$. Não existiam provas suficientes para determinar se os familiares da jovem tinham apresentando a denúncia no dia 11 ou 12 de outubro, mas em todo caso não tinha transcorrido o tempo de 72 horas desde o momento em que procuraram as autoridades estatais ${ }^{196}$.

Esmeralda Herrera tinha 15 anos de idade e desapareceu no dia 29 de outubro de 2001, após sair de casa onde trabalhava como empregada doméstica $^{197}$. No dia seguinte, foi feita a denúncia e o relatório de desaparecimento tem a mesma data ${ }^{198}$.

Em 6 de novembro de 2001, foram encontrados os corpos das três em uma plantação de algodão na cidade de Juárez, todas com sinais de abusos sexuais $^{199}$. As três jovens foram vítimas da violência contra a mulher e os crimes ocorreram por razões de gênero ${ }^{200}$. Necessário destacar que não existiam provas nos autos de que os responsáveis pelas mortes fossem agentes estatais ${ }^{201}$.

A Comissão IDH e os representantes das vítimas alegaram que as autoridades estatais tinham dito às mães das jovens que elas tinham que esperar 72 depois do desaparecimento, para que começassem as

\footnotetext{
${ }^{195}$ CORTE IDH. Caso González y otras (“Campo Algodonero”) Vs. México. Excepción Preliminar, Fondo, Reparaciones y Costas. Sentencia de 16 de noviembre de 2009. Serie C No.205, parágrafo 166.

${ }^{196}$ CORTE IDH. Caso González y otras (“Campo Algodonero") Vs. México. Excepción Preliminar, Fondo, Reparaciones y Costas. Sentencia de 16 de noviembre de 2009. Serie C No.205, parágrafo 166.

${ }^{197}$ CORTE IDH. Caso González y otras (“Campo Algodonero") Vs. México. Excepción Preliminar, Fondo, Reparaciones y Costas. Sentencia de 16 de noviembre de 2009. Serie C No.205, parágrafo 167.

${ }^{198}$ CORTE IDH. Caso González y otras (“Campo Algodonero") Vs. México. Excepción Preliminar, Fondo, Reparaciones y Costas. Sentencia de 16 de noviembre de 2009. Serie C No.205, parágrafo 173.

${ }^{199}$ CORTE IDH. Caso González y otras (“Campo Algodonero") Vs. México. Excepción Preliminar, Fondo, Reparaciones y Costas. Sentencia de 16 de noviembre de 2009. Serie C No.205, parágrafo 209.

${ }^{200}$ CORTE IDH. Caso González y otras (“Campo Algodonero") Vs. México. Excepción Preliminar, Fondo, Reparaciones y Costas. Sentencia de 16 de noviembre de 2009. Serie C No.205, parágrafo 231.

${ }^{201}$ CORTE IDH. Caso González y otras (“Campo Algodonero") Vs. México. Excepción Preliminar, Fondo, Reparaciones y Costas. Sentencia de 16 de noviembre de 2009. Serie C No.205, parágrafo 242.
} 
investigações. A Corte IDH pautou que não existiam provas suficientes acerca disto, mas, mesmo assim, levou em consideração as 72 horas de espera porque o Estado mexicano não demonstrou ações concretas que tinha realizado e como buscou efetivamente as vítimas durante o período mencionado $^{202}$.

\section{2 - Alegações das partes.}

A Comissão IDH alegou violação aos artigos $4^{\circ}, 5^{\circ}$ e $7^{\circ}$ da $\mathrm{CADH}$ manifestando que (i) o Estado mexicano não tinha adotado medidas razoáveis para proteger a vida e prevenir os assassinatos das três vítimas, apesar de que o Estado tinha conhecimento do risco iminente que elas corriam de serem assassinadas por haverem sido denunciadas como desaparecidas até a data dos fatos ${ }^{203}$.

Os representantes das vítimas completaram que (i) a morte das jovens fazia parte de um padrão de violência contra mulheres na Cidade de Juárez, mas Estado não tinha tomado as medidas necessárias com a devida diligência para evitá-las ${ }^{204}$.

O Estado do México sustentou apenas que tinha cumprido com as suas obrigações de prevenção, mas não especificou quais ${ }^{205}$. O Estado mexicano tinha reconhecido parcialmente a sua responsabilidade quanto ao momento das investigações das mortes das jovens ${ }^{206}$.

\footnotetext{
${ }^{202}$ CORTE IDH. Caso González y otras ("Campo Algodonero") Vs. México. Excepción Preliminar, Fondo, Reparaciones y Costas. Sentencia de 16 de noviembre de 2009. Serie C No.205, parágrafo 181.

${ }^{203}$ CORTE IDH. Caso González y otras (“Campo Algodonero") Vs. México. Excepción Preliminar, Fondo, Reparaciones y Costas. Sentencia de 16 de noviembre de 2009. Serie C No.205, parágrafo 249.

${ }^{204}$ CORTE IDH. Caso González y otras (“Campo Algodonero") Vs. México. Excepción Preliminar, Fondo, Reparaciones y Costas. Sentencia de 16 de noviembre de 2009. Serie C No.205, parágrafo 250.

${ }^{205}$ CORTE IDH. Caso González y otras (“Campo Algodonero") Vs. México. Excepción Preliminar, Fondo, Reparaciones y Costas. Sentencia de 16 de noviembre de 2009. Serie C No.205, parágrafo 251.

${ }^{206}$ CORTE IDH. Caso González y otras (“Campo Algodonero") Vs. México. Excepción Preliminar, Fondo, Reparaciones y Costas. Sentencia de 16 de noviembre de 2009. Serie C No.205, parágrafo 20 .
} 
Em sua análise, a Corte Interamericana considerou inicialmente a a sua competência para analisar a Convenção Belém do Pará. Isto porque tanto a Comissão IDH quanto os representantes das vítimas alegaram a violação do artigo 7.b do referido tratado. Em virtude disto, a Corte IDH estabeleceu, quanto a obrigação dos Estados frente ao dever de prevenção,

258. [...] A estratégia de prevenção deve ser integral, ou seja, deve prevenir os fatores de risco e por sua vez fortalecer as instituições para que possam proporcionar uma resposta efetiva aos casos de violência contra a mulher. Além disso, os Estados devem adotar medidas preventivas em casos específicos nos quais é evidente que determinadas mulheres e meninas podem ser vítimas de violência. Tudo isto deve levar em consideração que em casos de violência contra a mulher, os Estados têm, além das obrigações genéricas contidas na Convenção Americana, uma obrigação reforçada a partir da Convenção do Belém do Pará ${ }^{207}$ (Grifos nosso)

Tendo sido colocadas as orientações gerias, a Corte IDH passou analisar se no caso concreto o Estado mexicano tinha adotado medidas que demonstrassem o cumprimento do dever de prevenção.

Quanto ao conhecimento de uma situação de risco real ou imediato para um indivíduo ou grupo determinado, a Corte IDH considerou que o governo mexicano tinha conhecimento da situação de risco que as mulheres na cidade de Juárez sofriam, em virtude dos altos índices de criminalidade cometidos contra mulheres. Em suma, as mulheres eram objeto de violência na cidade mexicana e o governo tinha pleno conhecimento disso.

Quanto às medidas tomadas pelo governo mexicano, a Corte IDH disse expressamente que, não obstante o conhecimento da situação de risco, o Estado "não demonstrou ter adotado medidas efetivas de prevenção antes de novembro de 2001 que reduzissem os fatores de risco para as mulheres" 208 . Por ser uma obrigação de meio, a Corte Interamericana fez questão de demonstrar que o Estado não demonstrou que a criação da Promotoria

\footnotetext{
${ }^{207}$ CORTE IDH. Caso González y otras (“Campo Algodonero”) Vs. México. Excepción Preliminar, Fondo, Reparaciones y Costas. Sentencia de 16 de noviembre de 2009. Serie C No.205, parágrafo 258.

${ }^{208}$ CORTE IDH. Caso González y otras (“Campo Algodonero") Vs. México. Excepción Preliminar, Fondo, Reparaciones y Costas. Sentencia de 16 de noviembre de 2009. Serie C No.205, parágrafo 279.
} 
Especial para a Investigação de Homicídios de Mulheres e algumas adições a seu contexto legislativo, por mais que tenham sido necessárias e demonstrassem um compromisso estatal, foram suficientes e efetivas para prevenir as graves manifestações da violência contra as mulheres que viviam na cidade de Juárez na época do caso ${ }^{209}$.

Quanto à violação do dever prevenção, o Tribunal disse que existiam dois momentos importantes para serem analisados. O primeiro momento seria antes do desaparecimento das vítimas, o qual para a Corte IDH

282. [...] considera que a falta de prevenção do desaparecimento não leva, per se, à responsabilidade internacional do Estado porque, apesar de que este tinha conhecimento de uma situação de risco para as mulheres em Ciudad Juárez, não foi estabelecido que tinha conhecimento de um risco real e imediato para as vítimas deste caso ${ }^{210}$ (Grifos nosso).

Quanto ao segundo momento, qual seja, depois que as mães das jovens avisaram às autoridades dos desparecimentos de suas respectivas filhas, o Tribunal considerou que

283. [...] o Estado teve conhecimento de que existia um risco real e imediato de que as vítimas teriam sido agredidas sexualmente, submetidas a abusos e assassinadas. A Corte considera que, ante tal contexto, surge um dever de devida diligência estrita frente a denúncias de desaparecimento de mulheres, em relação à sua busca durante as primeiras horas e os primeiros dias. Esta obrigação de meio, ao ser mais estrita, exige a realização exaustiva de atividades de busca. Em particular, é imprescindível a atuação rápida e imediata das autoridades policiais, do Ministério Público e judiciais, ordenando medidas oportunas e necessárias dirigidas à determinação do paradeiro das vítimas ou do local onde possam se encontrar privadas de liberdade. Devem existir procedimentos adequados para as denúncias e que estas levem a uma investigação efetiva desde as primeiras horas. As autoridades devem presumir que a pessoa desaparecida está privada de liberdade e continua com vida até que seja posto fim à incerteza sobre o que ocorreu ${ }^{211}$. (Grifos nosso)

\footnotetext{
${ }^{209}$ CORTE IDH. Caso González y otras (“Campo Algodonero") Vs. México. Excepción Preliminar, Fondo, Reparaciones y Costas. Sentencia de 16 de noviembre de 2009. Serie C No.205, parágrafo 279.

${ }^{210}$ CORTE IDH. Caso González y otras (“Campo Algodonero") Vs. México. Excepción Preliminar, Fondo, Reparaciones y Costas. Sentencia de 16 de noviembre de 2009. Serie C No.205, parágrafo 282.

${ }^{211}$ CORTE IDH. Caso González y otras (“Campo Algodonero") Vs. México. Excepción Preliminar, Fondo, Reparaciones y Costas. Sentencia de 16 de noviembre de 2009. Serie C No.205, parágrafo 283.
} 
Percebe-se que o Tribunal levou em conta esse segundo momento para considerar violado o dever de prevenção e, por isto, julgou que o Estado mexicano tinha violado os artigos $4^{\circ}, 5^{\circ}$, e $7^{\circ}$ da CADH, em relação ao 1.1 , e também o artigo 7.b da Convenção Belém do Pará, considerando que o

284. [...] descumprimento do dever de garantia é particularmente sério devido ao contexto conhecido pelo Estado - o qual colocava as mulheres em uma situação especial de vulnerabilidade - e às obrigações reforçadas impostas em casos de violência contra a mulher pelo artigo 7.b da Convenção de Belém do Pará. ${ }^{212}$

Deste julgado podemos concluir importantes questões acerca do dever de prevenção. (i) o caso envolvia jovens mulheres em situações de vulnerabilidade. Logo, o dever de prevenção é mais acentuado do que em outras circunstâncias; (ii) a Corte IDH dá mais ênfase ao momento em que as mães das vítimas denunciam às autoridades estatais acerca do desaparecimento, mesmo considerando que antes dos desaparecimentos a Cidade de Juaréz apresentava alto índice de criminalidade contra as mulheres e ser uma região de alto risco e que (iii) o dever de prevenção foi analisado não apenas sob a ótica da Convenção Americana, mas também da Convenção Belém do Pará.

No próximo julgado, o caso selecionado é importante para o dever de prevenção porque, não obstante o Estado envolvido ter reconhecido integralmente a sua responsabilidade e a demanda ter resultado em uma solução amistosa ${ }^{213}$, a Corte IDH se pronunciou acerca do dever de prevenção em condições carcerárias $^{214}$. Além disto, o Tribunal não analisou os requisitos que configuram o dever de prevenção.

\footnotetext{
${ }^{212}$ CORTE IDH. Caso González y otras (“Campo Algodonero") Vs. México. Excepción Preliminar, Fondo, Reparaciones y Costas. Sentencia de 16 de noviembre de 2009. Serie C No.205, parágrafo 284.

${ }^{213}$ CORTE IDH. Caso Pacheco Teruel y otros Vs. Honduras. Fondo, Reparaciones y Costas. Sentencia de 27 de abril de 2012 Serie C No. 241, parágrafo 14.

${ }^{214}$ CORTE IDH. Caso Pacheco Teruel y otros Vs. Honduras. Fondo, Reparaciones y Costas. Sentencia de 27 de abril de 2012 Serie C No. 241, parágrafo 22.
} 


\section{6 - Caso Pacheco Teruel e Outro Vs. Honduras: Sentença de 27 de abril de $2012^{215}$.}

\section{1 - Contexto histórico e fatos do caso.}

A demanda se relaciona com a responsabilidade internacional do Estado pela morte de 107 internos privados de liberdade, em 17 de maio de 2004, em virtude de um incêndio que ocorreu no presídio San Pedro Sula. Em consequência do incêndio, 101 dos detentos morreram por sufocação por asfixia, e outros 6 faleceram no hospital por queimaduras graves. As mortes ocasionadas foram resultantes de uma serie de deficiências estruturais presentes no centro penitenciário onde estavam os presos, as quais eram de conhecimentos das autoridades competentes. As vítimas, presos das fações criminosas conhecidas como "maras", eram mantidas isoladas do resto da população carcerária e confinadas em um recinto inseguro e insalubre ${ }^{216}$.

$\mathrm{Na}$ época dos fatos, o sistema carcerário de Honduras apresentava deficiências estruturais, tais como as instalações elétricas, a água potável e sanitária, que estavam colapsadas ${ }^{217}$. Tais deficiências foram agravadas em consequência da implementação de reformas penais adotadas pelo Estado no marco das políticas de tolerância zero, com a finalidade de controlar a violência, contra as facções criminosas que atuavam no país ${ }^{218}$. Em consequência desta política, o número de pessoas encarceradas aumentou ainda mais, ainda mais nos presídios destinados aos criminosos pertencentes às "maras" 19 .

\footnotetext{
${ }^{215}$ CORTE IDH. Caso Pacheco Teruel y otros Vs. Honduras. Fondo, Reparaciones y Costas. Sentencia de 27 de abril de 2012 Serie C No. 241. Disponível em http://corteidh.or.cr/docs/casos/articulos/seriec_241_esp.pdf

${ }^{216}$ CORTE IDH. Caso Pacheco Teruel y otros Vs. Honduras. Fondo, Reparaciones y Costas. Sentencia de 27 de abril de 2012 Serie C No. 241, parágrafo 2.

${ }^{217}$ CORTE IDH. Caso Pacheco Teruel y otros Vs. Honduras. Fondo, Reparaciones y Costas. Sentencia de 27 de abril de 2012 Serie C No. 241, parágrafo 25.

${ }^{218}$ CORTE IDH. Caso Pacheco Teruel y otros Vs. Honduras. Fondo, Reparaciones y Costas. Sentencia de 27 de abril de 2012 Serie C No. 241, parágrafo 26.

${ }^{219}$ CORTE IDH. Caso Pacheco Teruel y otros Vs. Honduras. Fondo, Reparaciones y Costas. Sentencia de 27 de abril de 2012 Serie C No. 241, parágrafo 28.
} 
Em particular, no presídio San Pedro Sula, erem recorrentes os conflitos entre as facções ${ }^{220}$ e o Estado não contemplava programas educativos ou atividades de recreação para a reabilitação dos detentos ${ }^{221}$. Dois meses antes do incêndio, o diretor do centro penal enviou uma comunicação à gerente da Empresa Nacional de Energia Elétrica, solicitando a colaboração para melhorar ou corrigir o sistema elétrico dentro do presídio tendo em vista que estava colapsado e corria o risco de ocorrer um incêndio, principalmente na época do verão ${ }^{222}$.

$\mathrm{O}$ ingresso de eletrodomésticos era autorizado pelo diretor ${ }^{223}$ e o sistema de agua potável do centro era obsoleto e inadequado para satisfazer a demanda existente e não contava com hidrantes de incêndios para a conexão das mangueiras. A única instrução para as autoridades penitenciarias em casos de emergência era disparar um sinal de alerta e, para casos de incêndios, chamar os bombeiros ${ }^{224}$.

O incêndio no centro penal ocorreu no dia 17 de maio de 2004, tendo sua origem na cela $19^{225}$. A causa do incêndio foi devido ao excesso de aparelhos conectados, o que gerou um curto circuito no sistema elétrico do presídio de San Pedro Sula 226 .

\section{2 - Alegações das partes.}

Em relação a este caso, não foram disponibilizados os argumentos de cada parte porque o caso foi solucionado através do acordo amistoso entre.

\footnotetext{
${ }^{220}$ CORTE IDH. Caso Pacheco Teruel y otros Vs. Honduras. Fondo, Reparaciones y Costas. Sentencia de 27 de abril de 2012 Serie C No. 241, parágrafo 30.

${ }^{221}$ CORTE IDH. Caso Pacheco Teruel y otros Vs. Honduras. Fondo, Reparaciones y Costas. Sentencia de 27 de abril de 2012 Serie C No. 241, parágrafo 35.

${ }^{222}$ CORTE IDH. Caso Pacheco Teruel y otros Vs. Honduras. Fondo, Reparaciones y Costas. Sentencia de 27 de abril de 2012 Serie C No. 241, parágrafo 32.

${ }^{223}$ CORTE IDH. Caso Pacheco Teruel y otros Vs. Honduras. Fondo, Reparaciones y Costas. Sentencia de 27 de abril de 2012 Serie C No. 241, parágrafo 33.

${ }^{224}$ CORTE IDH. Caso Pacheco Teruel y otros Vs. Honduras. Fondo, Reparaciones y Costas. Sentencia de 27 de abril de 2012 Serie C No. 241, parágrafo 34.

${ }^{225}$ CORTE IDH. Caso Pacheco Teruel y otros Vs. Honduras. Fondo, Reparaciones y Costas. Sentencia de 27 de abril de 2012 Serie C No. 241, parágrafo 43.

${ }^{226}$ CORTE IDH. Caso Pacheco Teruel y otros Vs. Honduras. Fondo, Reparaciones y Costas. Sentencia de 27 de abril de 2012 Serie C No. 241, parágrafo 49.
} 
Quanto à análise do dever de prevenção em condições carcerárias, a Corte Interamericana, inicialmente, reiterou que o Estado tem o dever de garantir o direito à vida e a integridade pessoal dos presos, em razão que ele se encontra em uma posição especial de garante com relação aos presos, porque são as autoridades penitenciárias que exercem o controle total sobre os $\operatorname{presos}^{227}$.

Em função desta posição de garante, os Estados têm que planejar e executar uma política penitenciária de prevenção diante de situações críticas que ponham os direitos fundamentais dos presos em perigo, porque estes estão sob a custódia de agentes estatais ${ }^{228}$. Neste sentido, segundo a Corte Interamericana,

68. [...] el Estado debe incorporar en el diseño, estructura, construcción, mejoras, manutención y operación de los centros de detención, todos los mecanismos materiales que reduzcan al mínimo el riesgo de que se produzcan situaciones de emergencia ó incendios y en el evento que se produzcan estas situaciones se pueda reaccionar con la debida diligencia, garantizando la protección de los internos o una evacuación segura de los locales. Entre esos mecanismos se encuentran sistemas eficaces de detección y extinción de incendios, alarmas, así como protocolos de acción en casos de emergencias que garanticen la seguridad de los privados de libertad ${ }^{229}$.

Diante do exposto, a Corte Interamericana considerou que o Estado de Honduras era responsável pela violação doas artigos $4^{\circ}$ e $5^{\circ}$ da CADH porque

69. [...] frente al conocimiento de una situación crítica de riesgo, el Estado no garantizó los derechos de los internos a través de acciones preventivas y de actuación con la debida diligencia frente al incendio, lo que provocó muertes traumáticas y dolorosas. En este entendido, la Corte ha aceptado el reconocimiento de responsabilidad efectuado por Honduras, y por tanto concluye que el Estado violó el deber de garantizar los derechos consagrados en los artículos 4.1, 5.1, 5.2 y 5.6 de la Convención Americana, en relación con el artículo 1.1 de la misma, en perjuicio de las 107 personas privadas de libertad que perdieron la vida $[\ldots]^{230}$. (Grifo nosso)

227 CORTE IDH. Caso Pacheco Teruel y otros Vs. Honduras. Fondo, Reparaciones y Costas. Sentencia de 27 de abril de 2012 Serie C No. 241, parágrafo 63.

${ }_{228}$ CORTE IDH. Caso Pacheco Teruel y otros Vs. Honduras. Fondo, Reparaciones y Costas. Sentencia de 27 de abril de 2012 Serie C No. 241, parágrafo 68.

${ }^{229}$ CORTE IDH. Caso Pacheco Teruel y otros Vs. Honduras. Fondo, Reparaciones y Costas. Sentencia de 27 de abril de 2012 Serie C No. 241, parágrafo 68.

${ }^{230}$ CORTE IDH. Caso Pacheco Teruel y otros Vs. Honduras. Fondo, Reparaciones y Costas. Sentencia de 27 de abril de 2012 Serie C No. 241, parágrafo 69. 
A conclusão que podemos fazer deste caso é (i) o dever de prevenção foi analisado, mais uma vez, por atos cometidos por particulares e (ii) o Estado encontra-se em uma posição de garante frente aos presos, porque é ele que tem a responsabilidade pelas condições e pela vida e integridade física das pessoas presas.

O próximo caso selecionado, envolvendo outra vez um jornalista, é importante porque a Corte IDH destacou o fato de que, em certas circunstancias, uma investigação séria e oportuna das ameaças que a vítima recebe, pode contribuir com a prevenção da vulneração dos direitos que estavam sendo ameaçados ${ }^{231}$.

\section{7 - Caso Vélez Restrepo e Familiares Vs. Colômbia: Sentença de 3 de setembro de $2012^{232}$.}

\section{1 - Contexto histórico e fatos do caso.}

Luis Gonzalo Vélez Restrepo era um cinegrafista de um programa nacional de notícias no país e vivia, em Bogotá, junto com sua esposa e sus dois filhos 233 .

No dia 29 de agosto de 1996, o senhor Vélez Restrepo estava no Município de Morelia cobrindo os acontecimentos de um dos protestos contra a política governamental de queimada dos cultivos de coca, conhecidas como "marchas cocaleras"234.

Vélez Restrepo estava filmando os acontecimentos em uma zona, quando notou que alguns dos soldados começaram a golpear os agricultores com as pontas dos rifles e, por isto, começou a gravar o incidente. Três soldados se deram conta que o senhor Vélez Restrepo estava filmando o fato

\footnotetext{
${ }^{231}$ CORTE IDH. Caso Vélez Restrepo y Familiares Vs. Colombia. Excepción Preliminar, Fondo, Reparaciones y Costas. Sentencia de 3 de septiembre de 2012 Serie C No. 248, parágrafo 187.

${ }^{232}$ CORTE IDH. Caso Vélez Restrepo y Familiares Vs. Colombia. Excepción Preliminar, Fondo, Reparaciones y Costas. Sentencia de 3 de septiembre de 2012 Serie C No. 248. Disponível em http://corteidh.or.cr/docs/casos/articulos/seriec_248 esp.pdf

${ }^{233}$ CORTE IDH. Caso Vélez Restrepo y Familiares Vs. Colombia. Excepción Preliminar, Fondo, Reparaciones y Costas. Sentencia de 3 de septiembre de 2012 Serie C No. 248, parágrafo 77.

${ }^{234}$ CORTE IDH. Caso Vélez Restrepo y Familiares Vs. Colombia. Excepción Preliminar, Fondo, Reparaciones y Costas. Sentencia de 3 de septiembre de 2012 Serie C No. 248, parágrafo 78.
} 
e correram para a alcança-lo. Um Comandante de um batalhão ordenou que se confiscasse a câmara de vídeo do senhor Vélez Restrepo. Em seguida, ele foi agredido fisicamente por vários membros do exército nacional, os quais buscavam impedir que o cinegrafista continuasse filmando os atos dos militares $^{235}$.

Depois do ocorrido, a vítima recebeu várias ameaças contra ele e sua família. No dia 5 de outubro de 1997, o jornalista recebeu uma ameaça de morte por escrito e no dia seguinte foi alvo de uma tentativa de sequestro quando estava entrando no seu carro. Em virtude de todo o ocorrido, ele e a família resolveram sair da Colômbia em 9 de outubro de 1997, não podendo mais exercer sua função de jornalista ${ }^{236}$.

$\mathrm{Na}$ época dos fatos e nos anos posteriores, se apresentava na Colômbia um contexto de risco especial para os jornalistas e os comunicadores sociais em relação aos seus trabalhos, eram vítimas de atos de violência, ameaças e intimidações por membros de grupos do conflito armado interno que passava o país ${ }^{237}$.

\section{2 - Alegações das partes.}

A Comissão IDH e os representantes das vítimas alegaram a violação do artigo $5^{\circ}$ da CADH porque o (i) Estado da Colômbia tinha descumprido com a sua obrigação de garantir a integridade pessoal do jornalista e de seus familiares através da prevenção e investigação das ameaças, das intimidações e a tentativa de sequestro; (ii) o Estado colombiano violou a integridade psíquica e moral do senhor. Vélez Restrepo e de seus familiares porque não tinha adotado diligentemente e oportunamente as medidas necessárias para protegê-los das ameaças e intimidações que denunciaram frente as autoridades, que forma reiteradas a partir de 11 de setembro de 1996; (iii) o

\footnotetext{
${ }^{235}$ CORTE IDH. Caso Vélez Restrepo y Familiares Vs. Colombia. Excepción Preliminar, Fondo, Reparaciones y Costas. Sentencia de 3 de septiembre de 2012 Serie C No. 248, parágrafo 81.

${ }^{236}$ CORTE IDH. Caso Vélez Restrepo y Familiares Vs. Colombia. Excepción Preliminar, Fondo, Reparaciones y Costas. Sentencia de 3 de septiembre de 2012 Serie C No. 248, parágrafo 2.

${ }^{237}$ CORTE IDH. Caso Vélez Restrepo y Familiares Vs. Colombia. Excepción Preliminar, Fondo, Reparaciones y Costas. Sentencia de 3 de septiembre de 2012 Serie C No. 248, parágrafo 84.
} 
Estado tampouco realizou uma investigação que permitiria esclarecer e desativar as origens das intimidações e que (iv) as investigações são as mais importantes medidas de proteção para os jornalistas para cumprirem com seu trabalho e que o próprio Estado reconheceu que não houve um investigação efetiva $^{238}$.

Por sua vez, o Estado colombiano sustentou que (i) uma vez que as ameaças e intimidações foram postas em conhecimento das autoridades competentes em 6 de outubro de 1997, o Estado, através do Programa de Proteção do Ministério do Interior, proporcionou de maneira imediata diferentes meios de proteção e que três dias depois o senhor Vélez decidiu por vontade própria sair do país e que (ii) em relação a tentativa de sequestro ocorrida em 6 de outubro de 1997, o jornalista nunca solicitou proteção ou estudo de segurança algum por parte das autoridades estatais ${ }^{239}$.

No entender da Corte IDH, o Estado colombiano deveria adotar medidas especiais de prevenção e proteção aos jornalistas em decorrência do contexto de risco que eles viviam no país. Logo, em relação ao senhor Vélez Restrepo, o governo colombiano devia avaliar de forma diligente a necessidade de serem adotadas medidas de proteção oportunas em favor dele e de seus familiares ${ }^{240}$. Mais adiante a Corte IDH considerou importante, em relação aos jornalistas, ao indicar que

194. [...] los Estados tienen la obligación de adoptar medidas especiales de prevención y protección de los periodistas sometidos a un riesgo especial por el ejercicio de su profesión. Con respecto a las medidas de protección, la Corte destaca que los Estados tienen el deber de brindar medidas de protección a la vida y la integridad de los periodistas que estén sometidos a ese riesgo especial por factores tales como el tipo de hechos que cubren, el interés público de la información que difunden o la zona a la cual deben acceder para cumplir con su labor, así como también a aquellos que son objeto de amenazas en relación con la difusión de esa información o por denunciar o impulsar la investigación de violaciones que sufrieron o de las que se enteraron en el ejercicio de su profesión. Los Estados deben adoptar las medidas de protección necesarias para

\footnotetext{
${ }^{238}$ CORTE IDH. Caso Vélez Restrepo y Familiares Vs. Colombia. Excepción Preliminar, Fondo, Reparaciones y Costas. Sentencia de 3 de septiembre de 2012 Serie C No. 248, parágrafo 183 e 184. ${ }^{239}$ CORTE IDH. Caso Vélez Restrepo y Familiares Vs. Colombia. Excepción Preliminar, Fondo, Reparaciones y Costas. Sentencia de 3 de septiembre de 2012 Serie C No. 248, parágrafo 186.

${ }^{240}$ CORTE IDH. Caso Vélez Restrepo y Familiares Vs. Colombia. Excepción Preliminar, Fondo, Reparaciones y Costas. Sentencia de 3 de septiembre de 2012 Serie C No. 248, parágrafo 193.
} 
evitar los atentados la vida e integridad de los periodistas bajo tales condiciones ${ }^{241}$. (Grifos nosso)

Quanto ao conhecimento de uma situação de risco real ou imediato, a Corte IDH considerou que no contexto descrito e pela situação particular do senhor Vélez Restrepo que antes do episódio ocorrido em 6 de outubro de 1997, a vítima já se encontrava em uma situação de risco real e imediato pela sua integridade pessoal, assim como os membros de sua família ${ }^{242}$. Reforçando o fato de que o Estado colombiano tinha conhecimento da situação do senhor Vélez Restrepo, a Corte IDH

195. [...] puede concluir que desde mediados de septiembre de 1996 autoridades estatales tenían conocimiento de las amenazas y hostigamientos en contra del señor Vélez y su familia, así como también un funcionario estatal había suscrito un oficio poniendo en conocimiento de un órgano encargado de brindar seguridad la situación del señor Vélez Restrepo y su família ${ }^{243}$.

Quanto as medidas que poderiam ser tomadas, a Corte Interamericana estabeleceu importantes condições quanto ao dever de prevenção. Segundo o Tribunal, corresponde às autoridades estatais que tomam conhecimento de uma situação de risco especial, identificar ou valorar se a pessoa, que é objeto de ameaças ou intimidações, requer medidas de proteção ou passar para a autoridade competente para tomá-las, assim como oferecer a pessoa informação oportuna sobre as medidas disponíveis.

Um ponto chave foi que, para a Corte Interamericana, a valorização sobre se uma pessoa requer medidas de proteção e quais são adequadas é uma obrigação que corresponde ao Estado e não pode se restringir à própria vítima que solicite às autoridades competentes, nem que conheça com exatidão quem é a autoridade em melhor capacidade de atender a situação, tendo em

\footnotetext{
${ }^{241}$ CORTE IDH. Caso Vélez Restrepo y Familiares Vs. Colombia. Excepción Preliminar, Fondo, Reparaciones y Costas. Sentencia de 3 de septiembre de 2012 Serie C No. 248, parágrafo 194.

${ }^{242}$ CORTE IDH. Caso Vélez Restrepo y Familiares Vs. Colombia. Excepción Preliminar, Fondo, Reparaciones y Costas. Sentencia de 3 de septiembre de 2012 Serie C No. 248, parágrafo 195.

${ }^{243}$ CORTE IDH. Caso Vélez Restrepo y Familiares Vs. Colombia. Excepción Preliminar, Fondo, Reparaciones y Costas. Sentencia de 3 de septiembre de 2012 Serie C No. 248, parágrafo 195.
} 
vista que corresponde ao Estado estabelecer medidas de coordenação entre as suas entidades e funcionários ${ }^{244}$. Neste caminho, para o caso concreto a

201. La Corte resalta que para la época de los hechos del presente caso, no existía el Programa de Protección a Periodistas y Comunicadores Sociales creado en el 2000, y que los hechos de amenazas y hostigamientos fueron puestos en conocimiento de la Unidad de Investigaciones Especiales de la Procuraduría que se encontraba realizando una indagación por la agresión perpetrada al señor Vélez Restrepo el 29 de agosto de 1996 y ante una Fiscalía que se encargó de la investigación penal por el delito de amenazas ${ }^{245}$.

Depois de toda análise das provas e das alegações das partes, a Corte Interamericana acabou concluindo que

203. [...] El Estado no cumplió con su deber de prevenir la vulneración de los derechos del señor Vélez Restrepo y su familia a través de la adopción de medidas oportunas y necesarias de protección, sino recién después de que el señor Vélez Restrepo sufriera un intento de privación de la libertad, momento a partir del cual el Estado le ofreció varias medidas de protección que incluían la posibilidad de reubicarse en algún lugar del país para mitigar el riesgo denunciado $^{246}$. (Grifo nosso)

Podemos concluir deste julgado que (i) os jornalistas tais como os defensores de direitos humanos para exercerem a profissão de forma plena necessitam de uma maior atenção estatal quando o contexto não lhes são favoráveis, isto é, situações de violência, de intimidações, ameaças. Além disto, (ii) é essencial, quando o Estado tome conhecimento de uma situação de risco para uma pessoa ou um grupo determinado, que as autoridades sejam as responsáveis por tomar as melhores medidas possíveis, ou seja, não deve ficar a cargo da vítima quais são as medidas a serem adotadas.

O próximo caso, envolvendo um defensor de direitos humanos, foi selecionado porque foi um julgado em que a Corte IDH não considerou que o Estado tinha descumprindo com o seu dever de prevenir.

\footnotetext{
${ }^{244}$ CORTE IDH. Caso Vélez Restrepo y Familiares Vs. Colombia. Excepción Preliminar, Fondo, Reparaciones y Costas. Sentencia de 3 de septiembre de 2012 Serie C No. 248, parágrafo 201.

${ }^{245}$ CORTE IDH. Caso Vélez Restrepo y Familiares Vs. Colombia. Excepción Preliminar, Fondo, Reparaciones y Costas. Sentencia de 3 de septiembre de 2012 Serie C No. 248, parágrafo 201.

${ }^{246}$ CORTE IDH. Caso Vélez Restrepo y Familiares Vs. Colombia. Excepción Preliminar, Fondo, Reparaciones y Costas. Sentencia de 3 de septiembre de 2012 Serie C No. 248, parágrafo 203.
} 


\section{8 - Caso Castillo González e Outros Vs. Venezuela: Sentença de 27 de novembro de $2012^{247}$.}

\section{1 - Contexto histórico e os fatos do caso.}

O advogado Joe Luis Castillo González residia, junto com a sua esposa - Yelitze Moreno - e seu filho - Luis César Castillo Moreno - na cidade de Machiques, no Estado de Zulia, na Venezuela. Joe Luis era o coordenador geral da "Oficina de Acción Social y Derechos Humanos del Vicariato Apostólico de Machiques", onde, por razão do seu ofício, atuava na zona de fronteira da Venezuela com a Colômbia. Ele trabalhava em assuntos relacionados com povo indígenas e pessoas refugiadas, o que envolvia a orientação legal para as vítimas do conflito armado colombiano; assim como oferecia apoio legal para os campesinatos em assuntos relacionados com processos de recuperação de terras ${ }^{248}$.

$\mathrm{Na}$ referida zona fronteiriça onde atuava o advogado, aproximadamente entre 1999 e 2003, várias pessoas, provenientes do conflito armado colombiano, chegaram a Venezuela em busca de refúgio. Os Estados venezuelano que mais recebiam os refugiados eram Zulia, Táchira, Apure e Amazonas ${ }^{249}$.

Durante este período, se notou a presença de grupos armados colombianos na fronteira, o que gerava um clima de insegurança na zona, em virtude de sequestros, extorsões, roubos, contrabando, entres outros fatos que ocorriam na região. Por causa disso, o Estado venezuelano, que tinha conhecimento da situação complexa e de insegurança ${ }^{250}$, reforçou a segurança na fronteira através do aumento de vigilância policial e militar,

\footnotetext{
${ }^{247}$ CORTE IDH. Caso Castillo González y otros Vs. Venezuela. Fondo. Sentencia de 27 de noviembre de 2012. Serie C No. 256. Disponível em http://www.corteidh.or.cr/docs/casos/articulos/seriec_256_esp.pdf

${ }^{248}$ CORTE IDH. Caso Castillo González y otros Vs. Venezuela. Fondo. Sentencia de 27 de noviembre de 2012. Serie C No. 256, parágrafo 38.

${ }^{249}$ CORTE IDH. Caso Castillo González y otros Vs. Venezuela. Fondo. Sentencia de 27 de noviembre de 2012. Serie C No. 256, parágrafo 35.

${ }^{250}$ CORTE IDH. Caso Castillo González y otros Vs. Venezuela. Fondo. Sentencia de 27 de noviembre de 2012. Serie C No. 256, parágrafo 130.
} 
estabelecendo um comando estratégico na zona ${ }^{251}$. A segurança foi reforçada, em especial, no Estado de Zulia ${ }^{252}$.

Paralelo a essa situação, em 2001, foi promulgada "Ley de Tierras y Desarrollo Agrario", que regulamentava a reforma agrária venezuelana, o que ocasionou tensões entre os proprietários de terras e os campesinatos, produzindo numerosos atentados contra os líderes dos campesinatos. Concretamente, entre 2001 e 2002, haviam sido assassinados pelo menos cinco líderes na região ${ }^{253}$.

Neste contexto, no dia 27 de agosto de 2003, por volta das 19h30, o senhor Joe Castillo, junto com sua esposa e seu filho, estava dirigindo um carro até sua casa, quando dois homens desconhecidos, em uma motocicleta, começaram a disparar contra eles. Joe Castilho perdeu o controle do veículo, que coalizou contra a calçada ${ }^{254}$. O advogado morreu no hospital ${ }^{255}$ por causa dos vários disparos de balas que recebeu, enquanto sua esposa e filhos sobreviveram.

Importante destacar que, antes do atentado sofrido, Joe Castilllo não foi objeto de ameaças ou atos intimidatórios; não existiu uma denúncia pública perante autoridades estatais acerca de alguma situação de risco que afetava ele ou aos seus familiares, nem mesmo a necessidade de contar com medidas de proteção ${ }^{256}$.

\section{2 - Alegações das partes.}

Em sua manifestação sobre a violação do dever de prevenção, a Comissão IDH concluiu que não contava com elementos suficientes para

\footnotetext{
${ }^{251}$ CORTE IDH. Caso Castillo González y otros Vs. Venezuela. Fondo. Sentencia de 27 de noviembre de 2012. Serie C No. 256, parágrafo 36.

${ }^{252}$ CORTE IDH. Caso Castillo González y otros Vs. Venezuela. Fondo. Sentencia de 27 de noviembre de 2012. Serie C No. 256, parágrafo 130.

${ }^{253}$ CORTE IDH. Caso Castillo González y otros Vs. Venezuela. Fondo. Sentencia de 27 de noviembre de 2012. Serie C No. 256, parágrafo 36.

${ }^{254}$ CORTE IDH. Caso Castillo González y otros Vs. Venezuela. Fondo. Sentencia de 27 de noviembre de 2012. Serie C No. 256, parágrafo 42.

${ }^{255}$ CORTE IDH. Caso Castillo González y otros Vs. Venezuela. Fondo. Sentencia de 27 de noviembre de 2012. Serie C No. 256, parágrafo 43.

${ }^{256}$ CORTE IDH. Caso Castillo González y otros Vs. Venezuela. Fondo. Sentencia de 27 de noviembre de 2012. Serie C No. 256, parágrafo 132.
} 
atribuir a responsabilidade ao Estado da Venezuela, porque não existiam provas de que Joe Castillo tivesse sido objeto de ameaças antes de sua morte. Entretanto, alegou que, (i) pelo fato do governo venezuelano ter conhecimento da situação de violência que se passava na fronteira, isso bastaria para atribuir ao Estado a responsabilidade pela violação ao dever de prevenção ${ }^{257}$.

Por sua vez, os representantes das vítimas não concordaram com a Comissão. Segundo os representantes, a violação do dever de prevenção poderia ser atribuída ao Estado venezuelano com base em três elementos: i) a existência de um grupo vulnerável ou em situação de indefesa; ii) a existência de um padrão de violência sistemática e notória contra este grupo e iii) a ausência de uma política geral do Estado que seja suficiente e efetiva para remediar o padrão de violência. Com base nesses três requisitos, os representantes das vítimas argumentaram que

104. [...] que el caso de Joe Luis Castillo no es un caso aislado, siendo que la zona fronteriza de Venezuela se caracterizó en el período anterior a los hechos por varios factores de alto riesgo, incluyendo los efectos del conflicto colombiano, la presencia de un gran número de refugiados, y el tránsito de poblaciones en riesgo a través de la zona, sumado al conflicto que se escenificó en el proceso de reivindicación de tierras que se llevaba a cabo en el país ${ }^{258}$.

Sendo assim, os representantes das vítimas argumentaram que, pela falta de medidas de prevenção frente ao risco que existia para Luis Castillo, acabou acarretando em graves afetações à integridade pessoal dele, da esposa e também do seu filho ${ }^{259}$.

Em outras palavras, para os representantes das vítimas, a vulneração do dever de prevenção se baseava na conjugação de certas circunstancias que, para eles, formaria um risco estrutural, sendo uma delas a existência de um

\footnotetext{
257 CORTE IDH. Caso Castillo González y otros Vs. Venezuela. Fondo. Sentencia de 27 de noviembre de 2012. Serie C No. 256, parágrafo 101.

${ }^{258}$ CORTE IDH. Caso Castillo González y otros Vs. Venezuela. Fondo. Sentencia de 27 de noviembre de 2012. Serie C No. 256, parágrafo 104.

${ }^{259}$ CORTE IDH. Caso Castillo González y otros Vs. Venezuela. Fondo. Sentencia de 27 de noviembre de 2012. Serie C No. 256, parágrafo 105.
} 
padrão de violência sistemática e notória contra os defensores de direitos humanos ${ }^{260}$.

O Estado venezuelano manifestou que, (i) pela magnitude do conflito armado interno colombiano e sua penetração no território venezuelano, fatos como ocorridos com Joe Castilho nem sempre poderiam ser evitados. E que (ii) não se evidenciava nos autos a existência prévia de ameaças ou intimidações contra a família dele antes do atentado e nunca foram realizadas qualquer denúncia perante autoridades estatais acerca de uma possível situação de risco, nem a solicitação de medidas de proteção ${ }^{261}$.

Em sua análise acerca se ocorreu ou não violação ao dever de prevenção, a Corte Interamericana considerou que existia na região fronteiriça risco para atuação dos defensores humanos. Entretanto, quanto ao senhor Castillo González, o Tribunal entendeu que, antes do atentado, ele não foi objeto de ameaças ou atos de intimidação e também porque não existiu uma denúncia pública ou perante autoridades estatais de uma situação de risco que afetava o defensor de direitos humanos e os familiares, ou a necessidade de contar com medidas de proteção.

Para a Corte IDH, a situação de "risco estrutural" alegada pelos representantes das vítimas quanto aos defensores de direitos humanos, era uma situação geral da Venezuela e não exclusivamente do Estado de Zulia. Além disto, destacou que não se provou a existência de uma situação ou prática generalizada, nem sistemática de agressões contra defensores de direitos humanos na referida zona de fronteira ${ }^{262}$.

Sendo assim, a Corte IDH concluiu, que no momento dos fatos, não existiam elementos suficientes para estabelecer que o senhor Castillo se encontrava em uma situação de risco com especial notoriedade que ensejava

\footnotetext{
260 CORTE IDH. Caso Castillo González y otros Vs. Venezuela. Fondo. Sentencia de 27 de noviembre de 2012. Serie C No. 256, parágrafo 117.

261 CORTE IDH. Caso Castillo González y otros Vs. Venezuela. Fondo. Sentencia de 27 de noviembre de 2012. Serie C No. 256, parágrafo 106.

262 CORTE IDH. Caso Castillo González y otros Vs. Venezuela. Fondo. Sentencia de 27 de noviembre de 2012. Serie C No. 256, parágrafo 127.
} 
o Estado a adotar medidas especiais de proteção e prevenção a seu favor ${ }^{263}$. Em decorrência disto, a Corte IDH

132. [...] considera que el Estado no es responsable por la violación al derecho a la vida consagrado en el artículo 4 de la Convención, en relación con la obligación de garantía que emana de su artículo 1.1, en perjuicio de Joe Luis Castillo González. Por el mismo motivo, el Tribunal estima que el Estado tampoco es responsable de la vulneración del derecho a la integridad personal y derechos del niño, reconocidos en los artículos 5.1 y 19 de la Convención, en relación con el artículo 1.1 del mismo instrumento, en perjuicio de Yelitze Moreno, en lo que hace al primer derecho, y de Luis Castillo, en lo atinente a ambos artículos ${ }^{264}$. (Grifos nosso)

Podemos concluir deste caso que (i) ficou evidente que não basta apenas o conhecimento de uma situação de risco genérica, é necessário que a vítima ou alguém demonstre que naquela situação determinado indivíduo ou pessoa é objeto de uma situação de risco real ou imediato, seja fazendo uma denúncia pública ou perante autoridades estatais. Por isso que neste caso a Corte IDH não considerou violado o artigo $4^{\circ}$ em relação ao 1.1 da CADH.

O próximo caso foi selecionado porque a análise do dever de prevenção foi realizada em uma situação envolvendo um menor de idade que estava preso sob a custódia estatal.

\section{9 - Caso Hermanos Landaeta Mejías e Outros Vs. Venezuela: Sentença} de 27 de agosto de $2014^{265}$.

\section{1 - Contexto histórico e os fatos do caso.}

\footnotetext{
263 CORTE IDH. Caso Castillo González y otros Vs. Venezuela. Fondo. Sentencia de 27 de noviembre de 2012. Serie C No. 256, parágrafo 131.

264 CORTE IDH. Caso Castillo González y otros Vs. Venezuela. Fondo. Sentencia de 27 de noviembre de 2012. Serie C No. 256, parágrafo 132.

265 CORTE IDH. Caso Hermanos Landaeta Mejías y otros Vs. Venezuela. Excepciones Preliminares, Fondo, Reparaciones y Costas. Sentencia de 27 de agosto de 2014. Serie C No. 281. Disponível em http://corteidh.or.cr/docs/casos/articulos/seriec 281 esp.pdf
} 
O contexto deste caso está relacionado com a problemática de execuções extrajudiciais cometidos por policiais em diversos Estados venezuelanos, incluindo o Estado de Aragua ${ }^{266}$.

Em particular, se relaciona com a execução extrajudicial de dois irmãos, Igmar Alexander Landaeta Mejías e Eduardo José Landaeta Mejías, de 18 e 17 anos de idade respectivamente, por parte de funcionários do Cuerpo de Seguridad y Orden Público"do Estado de Aragua, na Venezuela. Eles eram filhos de María Magdalena Mejías e Ignacio Landaeta ${ }^{267}$.

Alexander Landaeta Mejías foi morto no dia 17 de novembro de 1996, por agentes policiais ${ }^{268}$. No dia 19 de novembro de 1996, a mãe dos jovens declarou, perante a imprensa, que em uma oportunidade um funcionário estatal tinha invadido a sua casa e lhe dito que iria matar qualquer um dos filhos dela e que não se importava que o denunciassem ao Ministério Público $^{269}$. No dia 20 de novembro do mesmo ano, María Magdalena testemunhou também, perante "la Seccional de Mariño", que agentes estatais insistiam que Eduardo Landaeta tinha presenciado a morte de uma pessoa em Sorocaima. A mãe de Eduardo manifestou que não sabia do paradeiro dele ${ }^{270}$. Mais de um mês depois, no dia 29 de dezembro de 1996, Eduardo Landaeta foi detido por agentes estatais do "Cuerpo de Seguridad y Orden Público" do Estado de Aragua, e levado para o "Cuartelito del Barrio de San Carlos", para uma suposta averiguação que se instruía perante a "Seccional

\footnotetext{
266 CORTE IDH. Caso Hermanos Landaeta Mejías y otros Vs. Venezuela. Excepciones Preliminares, Fondo, Reparaciones y Costas. Sentencia de 27 de agosto de 2014. Serie C No. 281, parágrafo 55 .

267 CORTE IDH. Caso Hermanos Landaeta Mejías y otros Vs. Venezuela. Excepciones Preliminares, Fondo, Reparaciones y Costas. Sentencia de 27 de agosto de 2014. Serie C No. 281, parágrafo 46.

${ }_{268}$ CORTE IDH. Caso Hermanos Landaeta Mejías y otros Vs. Venezuela. Excepciones Preliminares, Fondo, Reparaciones y Costas. Sentencia de 27 de agosto de 2014. Serie C No. 281, parágrafo 59.

${ }^{269}$ CORTE IDH. Caso Hermanos Landaeta Mejías y otros Vs. Venezuela. Excepciones Preliminares, Fondo, Reparaciones y Costas. Sentencia de 27 de agosto de 2014. Serie C No. 281, parágrafo 56.

270 CORTE IDH. Caso Hermanos Landaeta Mejías y otros Vs. Venezuela. Excepciones Preliminares, Fondo, Reparaciones y Costas. Sentencia de 27 de agosto de 2014. Serie C No. 281, parágrafo 57.
} 
de Mariño"271. Importante ressaltar que não existia qualquer ordem judicial ou ato flagrante que justificasse detenção de Eduardo ${ }^{272}$.

Neste mesmo dia, Eduardo informou aos seu pais que estava detido e estes foram imediatamente ao local. Ao chegarem, os pais informaram para uma funcionária que seu filho corria risco de vida, porque havia sido ameaçado em várias ocasiões por agentes estatais. A mesma respondeu aos pais para não se preocuparem, porque o comando central estava informado de que Eduardo era um menor de idade e que se apresentassem no dia seguinte para a transferência do seu filho ${ }^{273}$. No dia 30 de dezembro de 1996, Eduardo foi transferido para a "Estación Central"274.

No dia seguinte, ao ser transferido para a "Seccional de Mariño", por funcionários policiais em um veículo, Eduardo foi morto ${ }^{275}$. Neste ponto específico, o Estado da Venezuela alegou que o veículo fora interceptado por quatro sujeitos encapuzados, os quais pegaram as armas dos policiais que conduziam Eduardo e dispararam vários tiros contra o carro, ocasionado assim a morte do jovem ${ }^{276}$. Entretanto, a Corte IDH não acatou esta versão da Venezuela porque, com base no material probatório dos autos, “[...]el Estado no ha brindado una explicación convincente y satisfactoria sobre los hechos sucedidos al menor de edad bajo su custodia"277.

271 CORTE IDH. Caso Hermanos Landaeta Mejías y otros Vs. Venezuela. Excepciones Preliminares, Fondo, Reparaciones y Costas. Sentencia de 27 de agosto de 2014. Serie C No. 281, parágrafo 154.

272 CORTE IDH. Caso Hermanos Landaeta Mejías y otros Vs. Venezuela. Excepciones Preliminares, Fondo, Reparaciones y Costas. Sentencia de 27 de agosto de 2014. Serie C No. 281, parágrafo 164 .

273 CORTE IDH. Caso Hermanos Landaeta Mejías y otros Vs. Venezuela. Excepciones Preliminares, Fondo, Reparaciones y Costas. Sentencia de 27 de agosto de 2014. Serie C No. 281, parágrafo 70 .

274 CORTE IDH. Caso Hermanos Landaeta Mejías y otros Vs. Venezuela. Excepciones Preliminares, Fondo, Reparaciones y Costas. Sentencia de 27 de agosto de 2014. Serie C No. 281, parágrafo 71 .

275 CORTE IDH. Caso Hermanos Landaeta Mejías y otros Vs. Venezuela. Excepciones Preliminares, Fondo, Reparaciones y Costas. Sentencia de 27 de agosto de 2014. Serie C No. 281, parágrafo 154.

276 CORTE IDH. Caso Hermanos Landaeta Mejías y otros Vs. Venezuela. Excepciones Preliminares, Fondo, Reparaciones y Costas. Sentencia de 27 de agosto de 2014. Serie C No. 281, parágrafo 181 .

277 CORTE IDH. Caso Hermanos Landaeta Mejías y otros Vs. Venezuela. Excepciones Preliminares, Fondo, Reparaciones y Costas. Sentencia de 27 de agosto de 2014. Serie C No. 281, parágrafo 195. 
Neste caso nos interessa apenas os fatos ocorridos com a vítima Eduardo José Landaeta Mejías, porque o dever de prevenção está relacionado com as circunstâncias de sua morte.

\section{2 - Alegações das partes.}

Tanto a Comissão IDH quanto os representantes das vítimas alegaram, quanto ao dever de prevenção, a violação aos artigos $4^{\circ}$ e $19^{278}$ da $\mathrm{CADH}$ porque (i) a vítima estava sob custódia estatal, mas não se adotaram medidas necessárias - eles não especificaram quais seriam - para proteger a vida de Eduardo em sua situação especial de vulnerabilidade, tanto pela sua condição de criança quanto pelas ameaças que tinha recebido previamente de agentes estatais.

O Estado da Venezuela sustentou que (i) Eduardo Landaeta tinha sido executado por sujeitos encapuzados armados que tinham interceptado o veículo da polícia que transportava a vítima para outro local ${ }^{279}$.

Em suas considerações, acerca do direito à vida, a Corte IDH, inicialmente, destacou que os Estados devem tomar medidas necessárias para prevenir as execuções arbitrárias por parte de suas próprias forças de segurança, trata-se de uma obrigação negativa ${ }^{280}$. Em outras palavras, o Tribunal associa tal responsabilidade estatal ao dever de respeitar.

A Corte IDH manifestou que o Estado, quando se encontra em presença de crianças privadas de liberdade, “[...] tiene además de las obligaciones señaladas para toda persona, una obligación adicional establecida en el artículo 19 de la Convención Americana"281. Em

\footnotetext{
278 Artigo 19. Direitos da criança Toda criança tem direito às medidas de proteção que a sua condição de menor requer por parte da sua família, da sociedade e do Estado.

279 CORTE IDH. Caso Hermanos Landaeta Mejías y otros Vs. Venezuela. Excepciones Preliminares, Fondo, Reparaciones y Costas. Sentencia de 27 de agosto de 2014. Serie C No. 281, parágrafo 153.

280 CORTE IDH. Caso Hermanos Landaeta Mejías y otros Vs. Venezuela. Excepciones Preliminares, Fondo, Reparaciones y Costas. Sentencia de 27 de agosto de 2014. Serie C No. 281, parágrafo 181.

281 CORTE IDH. Caso Hermanos Landaeta Mejías y otros Vs. Venezuela. Excepciones Preliminares, Fondo, Reparaciones y Costas. Sentencia de 27 de agosto de 2014. Serie C No. 281, parágrafo 182.
} 
decorrência disto, o Estado encontra-se em uma posição de garante frente ao menor de idade que está sob custódia estatal.

Neste sentido, quando uma criança morre sob a custódia estatal como ocorreu com o Eduardo, a Corte IDH assinalou o seguinte parâmetro acerca do ônus probatório,

183. [...] Cuando una persona y, especialmente un niño, muere de manera violenta bajo su custodia, el Estado tiene la carga de demostrar que esta muerte no le es atribuible. La Corte ha indicado que recae en el Estado la obligación de proveer una explicación satisfactoria y convincente de lo sucedido a las personas bajo su custodia $y$ a desvirtuar las alegaciones sobre su responsabilidad, mediante elementos probatorios válidos ${ }^{282}$. (Grifos nosso)

Estabelecidas as referidas considerações quanto ao dever estatal frente ao artigo 19 da $\mathrm{CADH}$, o Tribunal passou analisar especificamente o dever de prevenção. No caso, a questão consistia em saber se configuraria " [...] la responsabilidad del Estado por falta de prevención, protección y, en su caso, respeto" 283 . (Grifo nosso)

Neste caminho, mais uma vez, o Tribunal verificou se foram preenchidos os requisitos que consubstanciam a mencionada obrigação, quais sejam,

184. [...] primeramente debe verificarse que al momento de los hechos existía una situación de riesgo real e inminente para la vida de un individuo o grupo de individuos determinados, que las autoridades conocían o debían tener conocimiento, y que no adoptaron las medidas necesarias dentro del ámbito de sus atribuciones que, juzgadas razonablemente, podían esperarse para prevenir o evitar ese riesgo ${ }^{284}$

A respeito da existência de uma situação de risco real e imediata, a Corte IDH considerou dois momentos específicos. O primeiro, um mês e meio antes da detenção de Eduardo, quando agentes estatais privaram a vida

282 CORTE IDH. Caso Hermanos Landaeta Mejías y otros Vs. Venezuela. Excepciones Preliminares, Fondo, Reparaciones y Costas. Sentencia de 27 de agosto de 2014. Serie C No. 281, parágrafo 183.

283 CORTE IDH. Caso Hermanos Landaeta Mejías y otros Vs. Venezuela. Excepciones Preliminares, Fondo, Reparaciones y Costas. Sentencia de 27 de agosto de 2014. Serie C No. 281, parágrafo 184.

284 CORTE IDH. Caso Hermanos Landaeta Mejías y otros Vs. Venezuela. Excepciones Preliminares, Fondo, Reparaciones y Costas. Sentencia de 27 de agosto de 2014. Serie C No. 281, parágrafo 184. 
do seu irmão, Igmar Landaeta e as declarações - 19 e 20 de novembro de 1996 - dadas pela mãe de Eduardo sobre as ameaças que recebera e a procura de funcionários públicos pelo seu filho ${ }^{285}$.

O segundo momento, a Corte IDH levou em conta o dia 29 de novembro de 1996, quando ocorreu a detenção ilegal, arbitrária e sem as garantias legais, de Eduardo porque não foi tomado em conta a sua condição de menor de idade, aumentando o risco existente ${ }^{286}$.

Quanto ao conhecimento das autoridades estatais deste risco, o Tribunal considerou atendido o respectivo requisito, porque os pais de Eduardo tinham informado sobre o perigo que o filho corria ao ter sido detido.

Quanto às medidas adotadas pelo Estado da Venezuela frente a esta situação de risco - prisão ilegal e arbitrária de um menor de idade e de seu conhecimento -, a Corte IDH considerou que as duas transferências pelas quais foram submetidas à vítima, acabaram por aumentar a situação de risco já existente em prejuízo do menor ${ }^{287}$. Neste ponto, foi bastante clara ao afirmar que

190. [...] que existen suficientes indicios para afirmar que, luego de la detención del menor de edad, los funcionarios tenían conocimiento de la situación de riesgo en que éste se encontraba, y no obstante ello, realizaron el segundo traslado a otra unidad policial, omitiendo proporcionarle las medidas de protección que le correspondían brindar a Eduardo Landaeta en su condición de menor de edad y por el riesgo en el que se encontraba ${ }^{288}$.

Por entender que estavam configurados todos os requisitos do dever de prevenção, a Corte IDH chegou a seguinte conclusão

\footnotetext{
285 CORTE IDH. Caso Hermanos Landaeta Mejias y otros Vs. Venezuela. Excepciones Preliminares, Fondo, Reparaciones y Costas. Sentencia de 27 de agosto de 2014. Serie C No. 281, parágrafo 185.

286 CORTE IDH. Caso Hermanos Landaeta Mejías y otros Vs. Venezuela. Excepciones Preliminares, Fondo, Reparaciones y Costas. Sentencia de 27 de agosto de 2014. Serie C No. 281, parágrafo 186.

287 CORTE IDH. Caso Hermanos Landaeta Mejías y otros Vs. Venezuela. Excepciones Preliminares, Fondo, Reparaciones y Costas. Sentencia de 27 de agosto de 2014. Serie C No. 281, parágrafo 189.

288 CORTE IDH. Caso Hermanos Landaeta Mejías y otros Vs. Venezuela. Excepciones Preliminares, Fondo, Reparaciones y Costas. Sentencia de 27 de agosto de 2014. Serie C No. 281, parágrafo 190.
} 
196. [...] constató la existencia de una situación de riesgo contra la vida de Eduardo Landaeta, así como el conocimiento de las autoridades estatales de un riesgo real e inminente en su perjuicio, mismo que se materializó en la privación de su vida. Dicho riesgo provenía de los propios agentes estatales, pertenecientes a la entidad que estaba a cargo de su custodia. Asimismo, esta Corte considera que existieron una serie de elementos concatenados que configuran un incumplimiento por parte del Estado a su deber de respeto y garantía a favor de Eduardo Landaeta, a saber: la referida problemática de abusos policiales en dicha época; las amenazas señaladas; la proximidad de la muerte de su hermano Igmar Landaeta, atribuible a agentes del mismo cuerpo policial; su detención ilegal y arbitraria en los términos descritos; la falta de protección especial en razón de su condición de menor de edad, así como del riesgo en el que se encontraba, siendo objeto de dos traslados sin ser puesto bajo control judicial ni autoridad competente de menores de edad por un tiempo prolongado; la falta de protección frente a los propios agentes implicados, el incumplimiento en su deber de custodia, así como todos los indicios que permiten inferir la responsabilidad directa de los agentes que lo trasladaban. En razón de ello, la Corte considera que el Estado es responsable por la privación arbitraria de la vida de Eduardo Landaeta, en incumplimiento de su deber de respeto y garantía del derecho a la vida de personas bajo su custodia, dispuesto en el artículo 4 de la Convención Americana, en relación con los artículos 1.1 y el 19 del mismo instrumento ${ }^{289}$. (Grifos nosso)

Deste penúltimo julgado, podemos extrair importantes considerações. A primeira delas é que (i) o Estado está em uma posição de garante frente aos menores de idade que estão sob a sua custódia, em especial pelo dever previsto no artigo 19 da $\mathrm{CADH}$; (ii) por consequência desta posição, o dever de prevenção estatal é mais acentuado e, a principal, é que (iii) o dever de prevenção foi analisado claramente sob a perspectiva da obrigação de respeitar uma vez que foram agentes estatais os responsáveis pela morte de Eduardo.

O último caso a ser analisado foi escolhido porque, como dito na introdução, tivemos a oportunidade de ajudar na elaboração sentença e, principalmente, porque foi o julgado que fomentou o desenvolver deste trabalho. Além disto, importante destacar, trata-se do último caso em que a Corte IDH, até o momento, enfrentou o dever de prevenção.

\footnotetext{
289 CORTE IDH. Caso Hermanos Landaeta Mejias y otros Vs. Venezuela. Excepciones Preliminares, Fondo, Reparaciones y Costas. Sentencia de 27 de agosto de 2014. Serie C No. 281, parágrafo 196.
} 


\section{0 - Caso Rodríguez Vera e Outros (Desaparecidos do Palácio de Justiça) Vs. Colômbia: Sentença de 14 de novembro de $2014^{290}$.}

\section{1 - Contexto histórico e os fatos do caso.}

Nos dias 6 e 7 de novembro de 1985 o grupo guerrilheiro conhecido como M-19 tomou violentamente as instalações do Palácio de Justiça, local onde era a sede da Corte Suprema de Justiça e do Conselho de Estado colombiano. O grupo tomou como reféns centenas de pessoas entre magistrados, magistrados auxiliares, advogados, empregados administrativos e de serviços, assim como visitantes de ambas corporações judiciais. Frente a esta incursão armada da guerrilha, que ficou conhecida como "a tomada do Palácio de Justiça", a resposta das forças de segurança do Estado é conhecida como a "retomada do Palácio de Justiça". A operação militar realizada foi qualificada como desproporcional e excessiva por tribunais internos e pela Comissão da Verdade sobre os fatos ocorridos ${ }^{291}$.

\section{Os antecedentes da tomada do Palácio de Justiçą ${ }^{292}$.}

O Movimento 19 de Abril ("M-19") era um grupo guerrilheiro que surgiu depois das eleições presidenciáveis de 1970. Antes da tomada do Palácio de Justiça, o grupo, no dia 30 de setembro de 1985, havia roubado um caminhão de entrega de leites em Bogotá, resultando na morte de 11 integrantes do grupo e um civil ficou ferido. No dia 23 de outubro o M-19

\footnotetext{
${ }^{290}$ CORTE IDH. Caso Rodríguez Vera y otros (Desaparecidos del Palacio de Justicia) Vs. Colombia. Excepciones Preliminares, Fondo, Reparaciones y Costas. Sentença de 14 de novembro de 2014. Serie $\quad$ C $\quad$ No. $287 . \quad$ Disponível em http://www.corteidh.or.cr/docs/casos/articulos/seriec 287 esp.pdf

${ }^{291}$ CORTE IDH. Caso Rodríguez Vera y otros (Desaparecidos del Palacio de Justicia) Vs. Colombia. Excepciones Preliminares, Fondo, Reparaciones y Costas. Sentença de 14 de novembro de 2014. Serie C No. 287, parágrafo 77.

${ }^{292}$ Boa parte dos fatos considerados provados pela Corte IDH foram extraídos do relatório final realizado pela Comissão da Verdade colombiana. Até em decorrência disto, a própria Corte IDH reservou os parágrafos $83 / 88$ para dizer acerca da importância do informe da Comissão da Verdade e do seu valor probatório.
} 
realizou um atentado em Bogotá contra o comandante do exército, o general Rafael Samudio Molina ${ }^{293}$.

Além destes acontecimentos, era amplamente conhecido por parte das forças militares e os organismos de segurança do Estado a possível tomada do Palácio de Justiça e a data aproximada, cuja finalidade era sequestrar os 24 magistrados da Corte Suprema. Neste sentido, em 16 de outubro de 1985, o comandante geral das forças militares recebeu uma carta anônima que dizia que o M-19 planejava tomar o edifício da Corte Suprema de Justiça no dia 17 de outubro quando os magistrados tivessem reunidos ${ }^{294}$.

Paralelamente a isto, desde meados de 1985 os magistrados da Corte Suprema de Justiça estavam recebendo ameaças de morte relacionadas com a questão envolvendo o tratado de extradição entre a Colômbia e os Estados Unidos. Os conselheiros do Estado também tinham recebido ameaças. Em resposta a estas ameaças, foi realizado um estudo da segurança física do Palácio de Justiça, investigações sobre a origem das ameaças e o governo assumiu a custodia pessoal de alguns magistrados. Adicionalmente, foi reforçada o serviço de vigilância do Palácio de Justiça composto por um contingente de um oficial, um suboficial e 20 agentes, o que foi cessado em 4 de novembro de 1985. No dia 6 de novembro de 1985 não estava presente a segurança que havia sido disposta no edifício em decorrência das ameaças e o Palácio de Justiça apenas contava com a mínima vigilância privada, formada por não mais que 6 empregados. Além disto, uns dias antes se haviam retirados os detectores de armas que se encontravam na entrada ${ }^{295}$.

\section{2 - Alegações das partes.}

\footnotetext{
293 CORTE IDH. Caso Rodríguez Vera y otros (Desaparecidos del Palacio de Justicia) Vs. Colombia. Excepciones Preliminares, Fondo, Reparaciones y Costas. Sentença de 14 de novembro de 2014. Serie C No. 287, parágrafo 89.

${ }^{294}$ CORTE IDH. Caso Rodríguez Vera y otros (Desaparecidos del Palacio de Justicia) Vs. Colombia. Excepciones Preliminares, Fondo, Reparaciones y Costas. Sentença de 14 de novembro de 2014. Serie C No. 287, parágrafo 89.

295 CORTE IDH. Caso Rodríguez Vera y otros (Desaparecidos del Palacio de Justicia) Vs. Colombia. Excepciones Preliminares, Fondo, Reparaciones y Costas. Sentença de 14 de novembro de 2014. Serie C No. 287, parágrafo 91.
} 
Quem alegou a violação ao deve de prevenir em relação aos artigos 4.1 e 5.1 da CADH foi tão somente ${ }^{296}$ os representantes das vítimas que manifestaram que (i) existia uma situação de risco real e imediata contra os magistrados da Corte Suprema de Justiça e do Conselho de Estado e contra as pessoas que trabalhavam no tribunal em virtude das ameaças recebidas; (ii) que a Colômbia não apenas tinha retirado a segurança existente de maneira injustificada, mas também incorrido na violação do dever de prevenção a respeito dos trabalhadores da cafeteria, dos visitantes e de Carlos Horácio Urán Rojas, que se encontravam no interior do Palácio de Justiça no momento da tomada por parte do M-19 e que (iii) estava plenamente acreditado que o Estado contava com informação exata e precisa sobre o dia e a hora em que o M-19 tomaria o Palácio de Justiça porque a retirada da proteção especial que havia no edifício tinha sido um ato deliberado da cúpula militar para permitir o ingresso do grupo guerrilheiro ${ }^{297}$.

Por sua vez, o Estado da Colômbia não se referiu expressamente acerca da violação ao dever de prevenção, mas controverteu os fatos que serviram como fundamento. Neste sentido, o governo colombiano alegou que (i) não tinha retirado de forma intencional a segurança do Palácio de Justiça para facilitar o ataque do M-19, porque as informações da tomada do tribunal de justiça tinham coincidido com a visita do Presidente francês ao país no dia 17 de outubro de 1985, razão principal pela qual se incrementou a segurança; (ii) a segurança policial do Palácio de Justiça tinha sido retirada por solicitude do Presidente da Corte Suprema e que (iii) a presença ou ausência da vigilância era indiferente para a execução da tomada do Palácio de Justiça, porque em nenhum momento se poderia ter previsto a magnitude do ato armado planejado pelo M-19298.

\footnotetext{
${ }^{296}$ A Comissão IDH apenas ressaltou que a situação de risco e ameaças contra os magistrados, assim como o retiro da segurança do Palácio de Justiça antes da tomada do prédio por parte do M-19, já faziam parte do marco fático do caso. Parágrafo 517 do caso.

297 CORTE IDH. Caso Rodríguez Vera y otros (Desaparecidos del Palacio de Justicia) Vs. Colombia. Excepciones Preliminares, Fondo, Reparaciones y Costas. Sentença de 14 de novembro de 2014. Serie C No. 287, parágrafo 515.

${ }^{298}$ CORTE IDH. Caso Rodríguez Vera y otros (Desaparecidos del Palacio de Justicia) Vs. Colombia. Excepciones Preliminares, Fondo, Reparaciones y Costas. Sentença de 14 de novembro de 2014. Serie C No. 287, parágrafo 523.
} 
A Corte IDH previamente se pronunciou no sentido de que apenas consideraria como vítimas, em relação ao descumprimento do dever de prevenção, as oito pessoas que se encontravam na cafeteria e o magistrado auxiliar Carlos Horácio Urán Rojas. Isto reforça a questão do requisito quanto ao grupo determinado.

Em suas considerações, a Corte IDH primeiro tratou da situação de risco do Palácio de Justiça e seus ocupantes. O Tribunal considerou provado que desde meados de1985 os magistrados da Corte Suprema e do Conselho de Estado haviam recebido ameaças de morte; as autoridades competentes tinham conhecimento das ameaças recebidas pelos magistrados, assim como dos fatores de risco que pesavam sobre os magistrados e que no dia 4 de novembro de 1985 a Polícia Nacional retirou a vigilância reforçada que prestava no Tribunal de Justiça colombiano, ficando aos cuidados de poucos vigilantes privados ${ }^{299}$.

Um ponto que merece destaque foi que a Corte Interamericana não acatou a alegação de que a retirada da segurança tinha sido uma solicitação do Presidente da Corte Suprema, porque era uma informação que se baseava em informes apresentados após a tomada do Palácio de Justiça e que até o momento da sentença não tinha sido demonstrado ${ }^{300}$.

Quanto ao conhecimento desta situação de risco, a Corte IDH afirmou que o Estado colombiano sabia das ameaças e dos planos do M-19 para tomar o Tribunal de Justiça do país, com base no acervo probatório do caso ${ }^{301}$.

A Corte Interamericana advertiu que diante de uma situação de risco real e imediato em que se encontravam os magistrados, os empregados e os visitantes do Palácio de Justiça, o Estado deveria ter adotado medidas

\footnotetext{
299 CORTE IDH. Caso Rodríguez Vera y otros (Desaparecidos del Palacio de Justicia) Vs. Colombia. Excepciones Preliminares, Fondo, Reparaciones y Costas. Sentença de 14 de novembro de 2014. Serie C No. 287, parágrafo 523.

${ }^{300}$ CORTE IDH. Caso Rodríguez Vera y otros (Desaparecidos del Palacio de Justicia) Vs. Colombia. Excepciones Preliminares, Fondo, Reparaciones y Costas. Sentença de 14 de novembro de 2014. Serie C No. 287, parágrafo 524.

301 CORTE IDH. Caso Rodríguez Vera y otros (Desaparecidos del Palacio de Justicia) Vs. Colombia. Excepciones Preliminares, Fondo, Reparaciones y Costas. Sentença de 14 de novembro de 2014. Serie C No. 287, parágrafo 525.
} 
pertinentes para a proteção daqueles e que jamais poderiam depender da vontade única do presidente do Tribunal de Justiça do país ${ }^{302}$.

Além disto, a Corte IDH recordou que a obrigação de prevenir violações de direitos humanos é de meio e não de resultado. Por conseguinte, independentemente se o assalto tivesse ocorrido ainda com a vigilância, a omissão do Estado em adotar todas as medidas que razoavelmente deveriam ser adotadas frente ao risco verificado, constituiu um descumprimento do seu dever de prevenção ${ }^{303}$.

Diante do exposto, a Corte IDH resumiu o seguinte

528. En virtud de todas las circunstancias expuestas supra, la Corte considera que (i) existía una situación de riesgo real e inmediato en perjuicio de los Magistrados de la Corte Suprema, Consejeros de Estado, demás empleados y visitantes del Palacio de Justicia; (ii) el Estado conocía dicho riesgo; pero (iii) no adoptó las medidas necesarias, suficientes y oportunas para contrarrestar ese riesgo, pues (iv) aún cuando llevó a cabo un estudio de seguridad y diseñó un plan de seguridad, dicho plan no se encontraba funcionando al momento de los hechos, cuando todavía persistía el riesgo. Por tanto, la Corte considera que el Estado no cumplió con su deber de prevenir y proteger adecuadamente a las 15 víctimas del presente caso que laboraban o se encontraban visitando el Palacio de Justicia, al momento de la toma por parte del M-19, a través de la adopción de medidas oportunas y necesarias de protección. La Corte reitera que los hechos del presente caso impactaron a más personas de las que están representadas actualmente ante esta Corte. No obstante, en el presente caso la Corte sólo tiene competencia para pronunciarse sobre las presuntas víctimas del presente caso, sin perjuicio de los recursos que otras posibles víctimas pudiesen interponer en el derecho interno ${ }^{304}$. (Grifos nosso)

Quanto à conclusão acerca da violação ou não dos artigos 4 e 5 da Convenção Americana,

530. [...] la Corte concluye que Colombia incumplió su obligación de garantizar los derechos a la vida y a la integridad personal, consagrados en los artículos 4.1 y 5.1 de la Convención, en relación con el artículo 1.1 del mismo

\footnotetext{
302 CORTE IDH. Caso Rodríguez Vera y otros (Desaparecidos del Palacio de Justicia) Vs. Colombia. Excepciones Preliminares, Fondo, Reparaciones y Costas. Sentença de 14 de novembro de 2014. Serie C No. 287, parágrafo 525.

303 CORTE IDH. Caso Rodríguez Vera y otros (Desaparecidos del Palacio de Justicia) Vs. Colombia. Excepciones Preliminares, Fondo, Reparaciones y Costas. Sentença de 14 de novembro de 2014. Serie C No. 287, parágrafo 527.

304 CORTE IDH. Caso Rodríguez Vera y otros (Desaparecidos del Palacio de Justicia) Vs. Colombia. Excepciones Preliminares, Fondo, Reparaciones y Costas. Sentença de 14 de novembro de 2014. Serie C No. 287, parágrafo 528.
} 
instrumento, por medio de la adopción de las medidas efectivas y necesarias para prevenir su vulneración ${ }^{305}$. (Grifos nosso)

Deste último julgado podemos concluir que (i) o caso envolveu atos cometidos por particulares; (ii) a Corte DIH reiterou os requisitos quanto ao dever de prevenção; (iii) a responsabilidade do Estado colombiano se deu pela omissão de medidas a serem adotadas frente a tomada do Palácio de Justiça e (iv) a Corte IDH deixou claro que o dever de prevenção foi analisado em relação a um grupo determinado.

${ }^{305}$ CORTE IDH. Caso Rodríguez Vera y otros (Desaparecidos del Palacio de Justicia) Vs. Colombia. Excepciones Preliminares, Fondo, Reparaciones y Costas. Sentença de 14 de novembro de 2014. Serie C No. 287, parágrafo 530. 


\section{CONCLUSÃO}

Este trabalho teve como principal objetivo verificar o modo que a Corte Interamericana estabeleceu, em determinados casos, o chamado dever de prevenção. Iniciamos o primeiro capítulo falando acerca do SIDH e sobre o papel e as funções desempenhadas pela Corte Interamericana; o segundo sobre a dupla obrigação prevista no artigo 1.1 da Convenção Americana e do conceito do dever de prevenção; no último, o núcleo deste trabalho, a análise dos dez julgados da Corte IDH tratando sobre o mencionado dever.

Ao final destes três capítulos abordados, é necessário agora fazer uma análise crítica da forma que, até o presente momento, a Corte IDH enfrentou o dever de prevenção e apresentar algumas mudanças quanto ao tema.

A partir dos dez julgados selecionados, percebemos que faltou consistência em alguns momentos quando a Corte Interamericana analisou o dever de prevenção. No primeiro julgado, quando a Corte Interamericana desenvolveu o dever de prevenção, Masacre De Pueblo Bello vs. Colômbia, fica bem claro que a referida obrigação estaria em discussão quando a violação dos direitos protegidos pela Convenção Americana fosse cometida por atos de particulares.

Ocorre que ao analisar os casos Comunidade Indígena Sawhoyamaxa Vs. Paraguai, Caso Ximenes Lopes Vs. Brasil, Pacheco Teruel e Outro Vs. Honduras e Hermanos Landaeta Mejías e Outros Vs. Venezuela, verificamos que o dever de prevenção foi considerado descumprido não por atos de particulares, mas sim por agentes estatais. No nosso entendimento, se um dos requisitos para o dever de prevenção é o "conhecimento de uma situação real de risco ou imediato para um indivíduo ou um grupo de indivíduos determinados", não faz nenhum sentido a Corte IDH analisar tal pressuposto quando são os próprios agentes estatais que violam a Convenção Americana, sob a perspectiva do dever de garantia. 
Isto porque os requisitos criados para verificar se o dever de prevenção não foi observado, decorrem da premissa de que a responsabilidade do Estado, por atos de particulares, não é ilimitada. Se particulares cometem alguma violação é necessário que o Estado previna, investigue e sancione os responsáveis. Situação bem diferente, é quando o próprio Estado comete o ato ilícito.

Em decorrência disto é que consideramos a falta de uma consistência acerca do dever de prevenção. O parâmetro inicialmente estabelecido pelo próprio Tribunal acabou não sendo seguido. Por conseguinte, percebemos que o enquadramento da responsabilidade estatal, em relação ao dever de prevenir, frente ao artigo 1.1 da Convenção Americana pode ir mais além da obrigação de garantia.

Acreditamos que o dever de prevenir poderia ter sido analisado também sob a ótica da obrigação de respeitar, porque assim abarcariam as violações de direitos humanos cometidos por agentes estatais.

Outra conclusão que retiramos é que, ao estabelecer as medidas que podem ser adotadas pelos Estados para cumprirem com o dever de prevenção - jurídica, política, administrativa ou cultural - a Corte Interamericana ainda pouco desenvolve como concretamente podem ser traduzidas as referidas medidas. Entendemos que esta "ausência" pode ser ou porque o Tribunal ainda não enfrentou situações que o permitam desenvolver melhor tais medidas ou porque as próprias partes - Comissão IDH, representantes das vítimas e o Estado demandado - não explorem muito o tema.

Relacionada com a questão supracitada, é a situação que envolve o segundo requisito do dever de prevenção, que é "possibilidades razoáveis de prevenir ou evitar esse risco". Trata-se de um pressuposto ainda pouco explorado pela Corte Interamericana. Isto se justifica também porque apenas com fundamento no caso concreto é que será possível determinar o que se entende por possibilidades razoáveis. A Corte IDH no caso Valle Jaramillo e Outros Vs. Colômbia estabeleceu certas medidas que poderiam ter sido adotadas pelo Estado colombiano frente a uma situação de risco real 
envolvendo um defensor de direitos humanos. Entretanto, em outros casos pouco fez referência a este requisito.

Ainda tratando sobre os requisitos do dever de prevenção, temos uma crítica quando a Corte IDH fala em risco real ou imediato "para um indivíduo ou um grupo de indivíduos determinados". Isto ficou bastante claro no caso Rodríguez Vera e Outros (Desaparecidos do Palácio de Justiça) Vs. Colômbia. Entendemos que o dever de prevenção poderia ter sido estabelecido para grupo de indivíduos determinados ou determináveis também.

Isto porque, em certas situações talvez, não será possível determinar o número exato de vítimas, por exemplo, uma explosão que afeta um bairro inteiro, um desmoronamento de terra que afetam diversas casas, uma poluição ambiental que afeta população de diferentes cidades, entres outras hipóteses. Ainda que não sejam todas que ajuízem uma demanda internacional contra o Estado, acreditamos que a análise do dever de prevenção pode ser feita. Afinal, avalia-se, no âmbito internacional dos direitos humanos, a responsabilidade estatal.

Tal posicionamento é corroborado pelo fato de que a Corte Interamericana já deferiu medidas provisórias $^{306}$ para proteção de uma pluralidade de pessoas que não haviam sido previamente nomeadas, mas que eram identificáveis e determináveis ${ }^{307}$. Não faz sentido limitar a obrigação de prevenir para grupos determinados, porque a responsabilidade internacional do Estado-parte da Convenção Americana será pelo descumprimento dos direitos nela previstos. Evidentemente, a presença de vítimas no julgamento de uma demanda é muito importante, mas isto não impede que, em certas situações particulares, a Corte IDH possa considerar o descumprimento do

\footnotetext{
${ }^{306} \mathrm{O}$ artigo 63.2 da CADH estabelece o seguinte: "2. Em casos de extrema gravidade e urgência, e quando se fizer necessário evitar danos irreparáveis às pessoas, a Corte, nos assuntos de que estiver conhecendo, poderá tomar as medidas provisórias que considerar pertinentes. Se se tratar de assuntos que ainda não estiverem submetidos ao seu conhecimento, poderá atuar a pedido da Comissão. ” ${ }^{307}$ CORTE IDH. Asunto de la Comunidad de Paz de San José de Apartadó. Medidas Provisórias. Resolução da Corte Interamericana de Direitos Humanos de 18 de junho de 2002, considerando oitavo; Asunto de las Comunidades del Jiguamiandó y del Curbaradó. Medidas Provisórias. Resolução da Corte Interamericana de Direitos Humanos de 6 de março de 2003, considerando nono.
} 
dever de prevenção para um grupo considerado determinável, englobando vítimas que não recorreram ao sistema regional americano de proteção dos direitos humanos.

No caso Rodríguez Vera e Outros (Desaparecidos do Palácio de Justiça) Vs. Colômbia a Corte disse que os fatos do caso tinham impactado em mais pessoas que estavam no Tribunal de Justiça colombiano, mas só tinha competência para se pronunciar sobre as vítimas do caso em relação ao descumprimento do dever de prevenção. Entendemos que a Corte IDH poderia ter considerado o descumprimento de forma genérica por parte Estado colombiano naquela situação da tomada do Tribunal de Justiça, não necessitando dizer que foi apenas para determinados indivíduos. A justificativa da Corte IDH também foi no sentido de que as outras pessoas afetadas poderiam ser valer de ações no âmbito interno. É verdade, mas ainda assim o Tribunal poderia ter avaliado o dever de prevenção como uma falha da Colômbia como um todo.

Outra situação que nos levou a refletir foi no caso González e outras ("Campo Algodonero") Vs. México, no qual foi estabelecido dois momentos chaves para determinar a responsabilidade do Estado mexicano pelo descumprimento do dever de prevenção.

Entendemos que o segundo momento - quando as mães das meninas denunciam o desaparecimento das suas filhas para autoridades estatais - na verdade se trata mais de um dever de investigar, da devida diligencia, de saber o que ocorreu com as jovens desaparecidas, não propriamente de um dever de prevenir. O primeiro momento também poderia ter sido considerado uma falha em prevenir porque o Estado mexicano tinha conhecimento do risco que existia na cidade de Juaréz para as mulheres, que eram vítimas constantes de violência e abusos na região. Logo, existia um risco real e imediato para todas as mulheres que ali se encontravam. A delimitação temporal poderia ser quanto a este risco, não quanto ao momento que as autoridades sabiam quem eram as jovens desaparecidas. Em virtude disto, 
consideramos que o México descumpriu com o dever de prevenção desde o primeiro momento.

Pode-se rebater tal ideia no sentido de que estaria sendo criado uma responsabilidade ilimitada para o Estado, porque em todas as situações de risco real ou imediato deveria ter um agente estatal presente para evitar a violação de algum direito. Acreditamos que pode ser afastada tal premissa, porque o ônus probatório estatal seria de demonstrar as medidas que foram concretamente tomadas e quais resultados obtidos com adoção daquelas para controlar e diminuir o risco real ou imediato existente.

Portanto, diante do que foi visto e analisado ao longo deste trabalho, o dever de prevenção pode ser reavaliado em relação aos requisitos que o configuram, com o objetivo de serem melhores analisadas as situações que ensejam o descumprimento do referido dever. Uma primeira mudança seria analisar o risco real ou imediato frente a um grupo determinado ou determinável; a outra seria a que Corte IDH concretamente aborde as medidas que podem ser adotados pelos Estados e que o Tribunal poderia também delimitar, temporalmente, a questão do dever de prevenção apenas quanto à existência de um risco real ou imediato e não quanto às vítimas.

Por fim, acreditamos que a principal mudança seria a Corte Interamericana avaliar o dever de prevenção não apenas sob a ótica da obrigação de garantia, mas também sob a obrigação de respeitar os direitos humanos consagrados na Convenção Americana, porque isto permitirá ao Tribunal construir uma jurisprudência mais sólida, precisa e coerente acerca do dever de prevenção. 


\section{BIBLIOGRAFIA}

\section{Livros}

PIOVESAN, Flávia. Direitos Humanos e o direito constitucional internacional. 14 a ed., rev. e atual. São Paulo: Saraiva, 2013, versão e-book, $782 \mathrm{p}$.

PIOVESAN, Flávia. Introdução ao Sistema Interamericano de Proteção dos

Direitos Humanos: A Convenção Americana de Direitos Humanos. In: $O$ sistema de proteção dos direitos humanos e o direito brasileiro. Coordenação Luiz Flávio Gomes, Flávia Piovesan. São Paulo: Editora Revista dos Tribunais, 2000, p. $17-52$.

GOMES, Luiz Flávio e MAZZUOLI, Valerio de Oliveira. Comentários à Convenção Americana sobre Direitos Humanos: Pacto de San José da Costa Rica. 4.ed. ver., atual.e ampl. São Paulo: Editora Revista dos Tribunais, 2013, 461 p.

MARTIN, Claudia e PINZÓN, Diego Rodríguez. La prohibición de la tortura y los malos tratos en el sistema interamericano: manual para víctimas y sus defensores. Serie de Manuales de la OMCT Vol.2, 2006, 271 p.

TRINDADE, Antônio Augusto Cançado. Os tribunais internacionais contemporâneos. Brasília: FUNAG, 2013, 132 p.

CASTAÑEDA, Mireya. El Derecho Internacional de los Derechos Humanos y su recepción nacional. Comisión Nacional de los Derchos Humanos. México, 2012, 271 p. 
NASH ROJAS, Claudio: El Sistema Interamericano de Derechos Humanos en acción. Aciertos y desafios. México: Porrúa, 2009, 304 p.

Corte IDH. Corte Interamericana de Derechos Humanos. Documentos Básicos em materia de derechos humanos en el sistema interamericano, 2012, 330 p.

\section{Opiniões Consultivas e Medidas Provisórias}

CORTE IDH. "Otros Tratados" Objeto de la Función Consultiva de la Corte (art. 64 Convención Americana sobre Derechos Humanos). Opinión Consultiva OC-1/82 del 24 de septiembre de 1982. Serie A No. 1.

CORTE IDH. Restricciones a la Pena de Muerte (Arts. 4.2 y 4.4 Convención Americana sobre Derechos Humanos). Opinión Consultiva OC-3/83 del 8 de septiembre de 1983. Serie A No. 3.

CORTE IDH. Interpretación de la Declaración Americana de los Derechos y Deberes del Hombre en el Marco del Artículo 64 de la Convención Americana sobre Derechos Humanos. Opinión Consultiva OC-10/89 del 14 de julio de 1989. Serie A No. 10.

CORTE IDH. Asunto de la Comunidad de Paz de San José de Apartadó respecto Colombia. Resolución de la Corte Interamericana de Derechos Humanos de 18 de junio de 2002.

CORTE IDH. Asunto Comunidades del Jiguamiandó y del Curvaradó respecto Colombia. Resolución de la Corte Interamericana de Derechos Humanos de 06 de marzo de 2003. 


\section{Julgados}

CORTE IDH. Caso Velásquez Rodríguez Vs. Honduras. Fondo. Sentencia de 29 de julio de 1988. Serie C No. 4.

CORTE IDH. Caso Baena Ricardo y otros Vs. Panamá. Fondo, Reparaciones y Costas. Sentencia de 2 de febrero de 2001. Serie C No. 72.

CORTE IDH. Caso de la Masacre de Pueblo Bello Vs. Colombia. Sentencia de 31 de enero de 2006. Serie C No. 140.

CORTE IDH. Caso Comunidad Indigena Sawhoyamaxa Vs. Paraguay. Fondo, Reparaciones y Costas. Sentencia de 29 de marzo de 2006. Serie C No. 146.

CORTE IDH. Caso Ximenes Lopes Vs. Brasil. Sentencia de 4 de julio de 2006. Serie C No. 149.

CORTE IDH. Caso Valle Jaramillo y otros Vs. Colombia. Fondo, Reparaciones y Costas. Sentencia de 27 de noviembre de 2008. Serie C No. 192.

CORTE IDH. Caso González y otras ("Campo Algodonero") Vs. México. Excepción Preliminar, Fondo, Reparaciones y Costas. Sentencia de 16 de noviembre de 2009. Serie C No.205.

CORTE IDH. Caso González Medina y familiares Vs. República Dominicana. Excepciones Preliminares, Fondo, Reparaciones y Costas. Sentencia de 27 de febrero de 2012 Serie C No. 240. 
CORTE IDH. Caso Pacheco Teruel y otros Vs. Honduras. Fondo, Reparaciones y Costas. Sentencia de 27 de abril de 2012 Serie C No. 241. CORTE IDH. Caso Vélez Restrepo y Familiares Vs. Colombia. Excepción Preliminar, Fondo, Reparaciones y Costas. Sentencia de 3 de septiembre de 2012 Serie C No. 248.

CORTE IDH. Caso Castillo González y otros Vs. Venezuela. Fondo. Sentencia de 27 de noviembre de 2012. Serie C No. 256.

CORTE IDH. Caso Hermanos Landaeta Mejías y otros Vs. Venezuela. Excepciones Preliminares, Fondo, Reparaciones y Costas. Sentencia de 27 de agosto de 2014. Serie C No. 281.

CORTE IDH. Caso Rodríguez Vera y otros (Desaparecidos del Palacio de Justicia) Vs. Colombia. Excepciones Preliminares, Fondo, Reparaciones y Costas. Sentencia de 14 de noviembre de 2014. Serie C No. 287.

\section{Documento}

CORTE IDH. Relatório Anual de 2012. Disponível em: $<$ http://www.corteidh.or.cr/sitios/informes/docs/POR/por_2012.pdf>.

Acesso em 27 de outubro de 2015.

\section{Artigo}

MAC-GREGOR, Eduardo Ferrer e PELAYO MÕLLER, Carlos María. La obligación de 'respetar' y 'garantizar' los derechos humanos a la luz de la jurisprudencia de la Corte Interamericana. In: Estudios Constitucionales, Año 10, $\mathrm{N}^{\mathrm{o}} 2$ 2012, p. 141 - 192. Disponível em: $<$ http://www.cecoch.cl/docs/pdf/revista_10_2_2012/la_obligacion_Eduardo \%20Ferrer_Carlos_Pelayo.pdf>. Acesso em 29 de outubro de 2015. 
Pontifícia $U_{\text {niversidade }}$ C $_{\text {atólica }}$

NORMAS PARA ELABORAÇÃO E APRESENTAÇ̃̃O DA MONOGRAFIA
JUR 1919 OU JUR 1916

ANEXO II

A Monografia deve ser entregue até o dia 10 de novembro de 2015.

A presente Monografia, apresentada pelo (a) aluno (a)

poderá

ser submetida à exposição e defesa perante a Banca Examinadora designada pelo Departamento de Direito da PUC-Rio.

Rio de Janeiro, de de 2015.

Nome do (a) professor (a) orientador (a)

Assinatura do (a) professor (a) orientador (a)

O (A) autor (a) declara para todos os fins de Direito ser este um trabalho inédito de sua autoria e autoriza o Departamento de Direito da PUC-Rio a divulgá-lo, no todo ou em parte, resguardados os direitos autorais conforme legislação vigente.

Rio de Janeiro, de 2015. 